\title{
DPb-MOPSO: A Novel Dynamic Pareto bi-level Multi-Objective Particle Swarm Optimization Algorithm
}

This paper was downloaded from TechRxiv (https://www.techrxiv.org).

\section{LICENSE}

CC BY 4.0

SUBMISSION DATE / POSTED DATE

$15-12-2021 / 21-12-2021$

\section{CITATION}

Aboud, Ahlem; Rokbani, Nizar; Fdhila, Raja; Qahtani, Abdulrahman M.; Almutiry, Omar; dhahri, habib; et al. (2021): DPb-MOPSO: A Novel Dynamic Pareto bi-level Multi-Objective Particle Swarm Optimization Algorithm. TechRxiv. Preprint. https://doi.org/10.36227/techrxiv.17207576.v1

$\mathrm{DOI}$ 


\section{DPb-MOPSO: A Novel Dynamic Pareto bi-level Multi-Objective Particle Swarm Optimization Algorithm}

Ahlem Aboud Member, IEEE, Nizar Rokbani, Raja Fdhila, Abdulrahman M. Qahtani, Omar Almutiry, Habib Dhahri, Amir Hussain and Adel M. Alimi Senior Member, IEEE

\begin{abstract}
Particle swarm optimization system based on the distributed architecture has shown its efficiency for static optimization and has not been studied to solve dynamic multiobjective problems (DMOPs). When solving DMOP, tracking the best solutions over time and ensuring good exploitation and exploration are the main challenging tasks. This study proposes a novel Dynamic Pareto bi-level Multi-Objective Particle Swarm Optimization (DPb-MOPSO) algorithm including two parallel optimization levels. At the first level, all solutions are managed in a single search space. When a dynamic change is successfully detected, the Pareto ranking operator is used to enable a multiswarm subdivisions and processing which drives the second level of enhanced exploitation. A dynamic handling strategy based on random detectors is used to track the changes of the objective function due to time-varying parameters. A response strategy consisting in re-evaluate all unimproved solutions and replacing them with newly generated ones is also implemented. Inverted generational distance, mean inverted generational distance, and hypervolume difference metrics are used to assess the DPbMOPSO performances. All quantitative results are analyzed using Friedman's analysis while the Lyapunov theorem is used for stability analysis. Compared with several multi-objective evolutionary algorithms, the DPb-MOPSO is robust in solving 21 complex problems over a range of changes in both the Pareto optimal set and Pareto optimal front. For 13 UDF and ZJZ functions, DPb-MOPSO can solve 8/13 and 7/13 on IGD and HVD with moderate changes. For the 8 FDA and dMOP benchmarks, DPb-MOPSO was able to resolve 4/8 with severe change on MIGD, and 5/8 for moderate and slight changes. However, for the 3 kind of environmental changes, DPb-MOPSO assumes $4 / 8$ of the solving function on IGD and HVD.
\end{abstract}

Index Terms-Dynamic Multi-Objective Optimization, Dynamic Particle Swarm Optimization, Dynamic Problems, Detectors, Dynamic Response, Friedman Analysis of Variance, Lyapunov Theorem.

\section{INTRODUCTION}

$\mathrm{D}$ YNAMIC Multi-Objective Optimization (DMOO) approaches target to solve Dynamic Multi-Objective Problems (DMOPs), which may have two or three conflicting functions characterized by time-varying objectives, parameters, and/or constraints. Farina et al.[1] categorized DMOPs into four types. For type I, the Pareto Optimal Set (POS) changes, and the Pareto Optimal Front (POF) remains unchanged, while for type II both POS and POF change over time. However, the

A. Aboud is with University of Sousse, ISITCom, 4011, Sousse, Tunisia; and with REsearch Groups in Intelligent Machines (REGIM Lab), University of Sfax, National Engineering School of Sfax (ENIS), BP 1173, Sfax, 3038, Tunisia; (E-mail: ahlem.aboud@ regim.usf.tn).

N. Rokbani is with the High Institute of Applied Science and technology of Sousse, University of Sousse, Tunisia and with REsearch Groups in Intelligent Machines (REGIM Lab), University of Sfax, National Engineering School of Sfax (ENIS), BP 1173, Sfax, 3038, Tunisia; (E-mail: nizar.rokbani@ ieee.org).

R. Fdhila is with REsearch Groups in Intelligent Machines (REGIM Lab), University of Sfax, National Engineering School of Sfax (ENIS), BP 1173, Sfax, 3038, Tunisia. (E-mail: raja.fdhila@ieee.org).
POF changes, and the POS remains constant for DMOPs in type III. Finally, for type IV, and despite the environmental changes both POS and POF keep unchanged. Multi-Objective Evolutionary Algorithms (MOEAs) and bio-inspired intelligent techniques like the Genetic Algorithm (GA) [2], and the Particle Swarm Optimization (PSO) method [3]- [5] has being investigated to manage the evolutionary stagnation issues for static single/multi-objective optimization. A set MOEAs has being established as suitable for dynamic multi-objective optimization in [6] and [8], where proposals were able to find the best compromise solutions set on POS and POF, while tracking environmental changes.

Several PSO approaches has been proposed for dynamic single-objective optimization problems (DSOPs) [9]. It should be noted, that the standard PSO method [3] is not very efficient with DMOP because of its limited capacities in addressing the dual issue of the outdated memory and the loss of diversity. A well-known mechanism to overcome this problem consists in using an amount of randomly selected outdated population to re-evaluate the values of objectives and constraints. In addition, reinitialization and hypermutation have been explicitly used to ensure good convergence and diversity in the dynamic search space [10], [11]. Nonetheless, genetic and population-based strategies on distributed methods are considered for static optimization [12] and have not yet been processed for DMOPs. Besides, many of the transfer learning-based methods [13] proposed for DMOPs are time-consuming, which increases the diminishing of solutions diversity. Furthermore, does not exist any approach that uses multi-objective particle swarm optimization (MOPSO) with a distributed architecture to solve DMOPs. The standard MOPSO [14] algorithm stagnated in local optima and loss diversity over time.

This research focuses on proposing a Dynamic Pareto bilevel Multi-Objective Particle Swarm Optimization (DPbMOPSO). The system adopts a distributed architecture with two parallel optimization levels to handle DMOPs with various types of changes on POS and POF. For the upper level $\left(L_{1}\right)$, the swarm acts in a single search space, pushing all particles to the best-compromise solutions. Nevertheless, if a dynamic change is successfully detected at the first level, the second level processing provides exploitation enhancement over a dynamic multi-swarm subdivision based on the Pareto ranking operator.

A. M. Qahtani is with Department of Computer Science, College of Computers and Information Technology, Taif University, P.O.Box. 11099, Taif 21944, Saudi Arabia. (E-mail: amqahtani@tu.edu.sa).

O. Almutiry and H. Dhahri are with College of Applied Computer Science, King Saud University, Riyadh, Saudi Arabia. (E-mails: oalmutiry@ksu.edu.sa, hdhahri@ksu.edu.sa).

A. Hussain is with Edinburgh Napier University, School of Computing, Edinburgh EH10 5DT, Scotland, U.K. (E-mail: a.hussain@napier.ac.uk).

A. M. Alimi is with REsearch Groups in Intelligent Machines (REGIM Lab), University of Sfax, National Engineering School of Sfax (ENIS), BP 1173, Sfax, 3038, Tunisia; and with Department of Electrical and Electronic Engineering Science, Faculty of Engineering and the Built Environment, University of Johannesburg, South Africa. (E-mail : adel.alimi@ieee.org). 
$\mathrm{DPb}-\mathrm{MOPSO}$ proposes a dynamic handling strategy to detect and effectively respond to changes. For the detection strategy, $10 \%$ of the randomly selected solutions $\operatorname{POS}(\mathrm{t})$ have been used as detectors and compared with the previous solutions POS(t1). The response strategy consists in re-evaluating all solutions with negative improvement and replaced them with new random solutions. Solutions with positive progress are transferred to build a new population in order to speed up the optimization process after changes. Non-dominated solutions are then re-evaluated in the archive to avoid outdated memory issue.

The state of the art involves comparable algorithms to the novel DPb-MOPSO system based essentially on three metrics [11]: Inverted Generational Distance (IGD), Mean Inverted Generational Distance (MIGD), and Hypervolume Difference (HVD) metrics. Including, five MOEAs, namely Multiobjective Evolutionary Algorithm Based on Decomposition (MOEA/D) [15], dynamic Competitive-cooperative coevolutionary Algorithm (dCOEA) [16], Population Prediction Strategy (PPS) [17], Dynamic Non-dominated Sorting Genetic Algorithm II (DNSGA-II) [18] and Steady-State Generational Evolutionary Algorithm (SGEA) [19]. Four PSO-based methods which are: Dual multi-objective particle swarm optimization (dMOPSO) [20], distributed Multi-Objective Particles Swarms Optimization, based on dynamic subdivision of the population using Pareto fronts (pbMOPSO) [12] and Multi-Objective Particles Swarms Optimization (MOPSO) [14], and Dynamic-MOPSO [9]. The six methods based on transfer learning [13] are; MMTL-MOEA/D, RIMOEA/D [13], KF-MOEA/D [21], PPS-MOEA/D [17], SVR-MOEA/D [22] and Tr-MOEA/D [23] approaches.

The remaining of this paper is organized as follows. Section II introduces the overview of dynamic multi-objective optimization methods in detail. Section III details the proposed $\mathrm{DPb}-\mathrm{MOPSO}$. Section IV introduces the preliminary of the experimental study. The analysis and discussion of the results are shown in Section V. The Lyapunov theorem used for stability analysis is presented in Section VI. Finally, Section VII summarizes the paper and suggest some prospects for future works.

\section{DYNAMIC MULTI-OBJECTIVE OPTIMIZATION METHODS}

Several studies were interested in dynamic multi-objective optimization at three research levels, and therefore include the development of benchmarks, algorithms and quality indicators. Generally, a dynamic multi-objective optimization problem $f_{t}$ which has $m$ time-varying objective function, and solved by an algorithm $G$ in a given time period $\left[t_{\text {began }}, t_{\text {end }}\right]$ by be expressed as in Equation 1.

$$
\begin{aligned}
& \text { Minimize } F(x, t)=\left(f_{1}(x, t), f_{2}(x, t), \ldots, f_{n_{m}}(x, t)\right) \\
& \text { Subject to: } g_{i}(x, t) \leq 0 \text { and } h_{j}(x, t)=0 \forall i, j=1, \ldots, n \\
& \qquad x \in\left[x_{\text {min }}, x_{\text {max }}\right], t \in\left[t_{\text {begin }}, t_{\text {end }}\right]
\end{aligned}
$$

Among DMOPs, the following are well used in cooperative analysis: three dMOP problems such in [16], five continuous FDA functions such in [1] including dynamic shift on POF and POS, five ZJZ (F5 to F10) [17] with non-linear correlation between decision variables, nine Unconstrained Dynamic Functions (UDFs) [24] and a set of real-world problems [25]. Five categories of MOEAs have been also proposed for DMOP and classified in Table I. The first category is the standard MOEAs designed for static multi-objective optimization and considered for DMOP. Among them the Strength Pareto Evolutionary Algorithm 2 (SPEA2) [26], Non-dominated Sorting Genetic Algorithm II (NSGA-II) [2], MOEA/D [15], and dCOEA [16].

Furthermore, a set of Transfer Learning-based (TL) methods were proposed to construct a predictive model that can learn from previous experience to predict future changes. Several TL methods have been proposed based on the baseline MOEA/D system [15]. When the environment changes, the modified MOEA/D algorithm with random initialization (RI-MOEA/D) [13] generates $10 \%$ of the new population. The Transfer Learning-based Dynamic Multi-objective Optimization Algorithm (TR-MOEA/D) [23] aims to manage nonindependent, identically distributed solutions. The TRMOEA/D algorithm determines the best potential space to select the optimal values of numerous hyper-parameters after each change. Memory-driven Manifold Transfer Learning algorithm (MMTL-MOEA/D) [13] were used to predict the initial population based on the elite of the previous solutions. The Kalman Filter (KF) prediction model based on MOEA/D (KF-MOEA/D) [21] uses a priori estimation to predict the posterior experience. An alternative Support Vector Regression MOEA/D (SVR-MOEA/D) [22] has also been proposed to predict the new population over time. The PPS-MOEA/D system was proposed in [17] based on an autoregressive model to predict the center point and the manifold based on previous experience.

Moreover, different diversity-based approaches maintain population diversity through a re-initialization or a hypermutation behavior after each transition or throughout the execution time. DNSGA-II-A and DNSGA-II-B [18] selects a random solution, and asses its re-evaluation to monitor any environmental change. The Dynamic Constrained NSGA-II (DC-NSGA-II) [27] proposed an adaptive penalty function to deal with time-varying constraints. In order to maintain diversity over time, the Dynamic-MOPSO system [9] controls the evolution of the objective function and reinitializes non suitable solutions. A memory-based method is proposed in dynamic Competitive-cooperative co-evolutionary Algorithm (dCOEA) [16]. In [28] an Adaptive Dynamic NSGA-II (A-DyNSGA-II) used an additional memory mechanism to implicitly or explicitly store outdated individuals for potential use. Steady-State Generational Evolutionary Algorithm (SGEA) [19] aims to reuse outdated solutions with good distribution to relocate solutions closer to the new POF. Different parallel methods with multiple sub-populations are used for DMOPs such in [8] and [29]. However, a set of performance indicators [11] have been considered for accuracy, diversity, and robustness measurements. Ultimately, convergence and diversity are measured using IGD, MIGD, and HVD quality indicators.

The PSO approach proposed in this paper tends to overcome the limitations of the surveyed MOEAs and the high computational time issue of transfer-learning methods when solving DMOPs. Despite all the additional mechanisms to detect and effectively react to changes, many EAs fail to assume good convergence and diversity in the dynamic search space. More details about the proposed DPb-MOPSO are presented in 
the next section.

TABLE I. DYNAMIC MULTI-OBJECTIVE OPTIMIZATION METHODS REVIEW

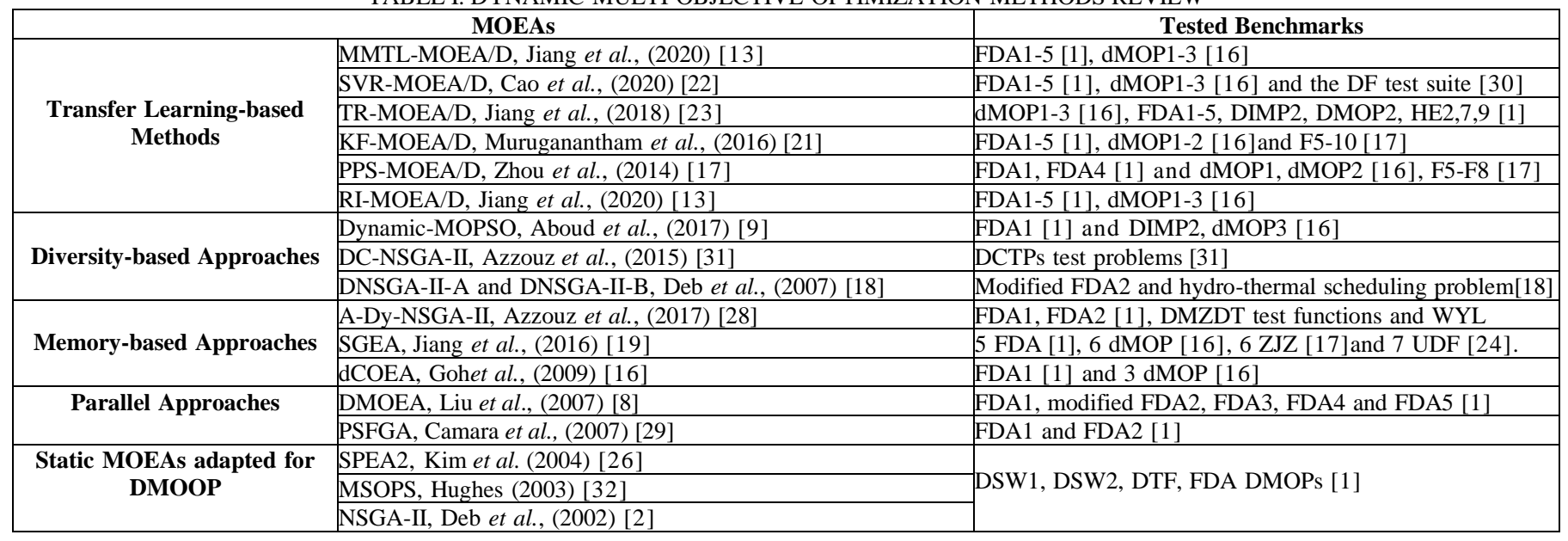

\section{THE DYNAMIC PARETO BI-LEVEL MULTI- OBJECTIVE PARTICLE SWARM OPTIMIZATION}

The proposed Dynamic Pareto bi-level Multi-Objective Particle Swarm Optimization (DPb-MOPSO) approach is shown in Figure 1. DPb-MOPSO has two optimization levels, called the upper $\left(L_{1}\right)$ and the lower $\left(L_{2}\right)$ levels. These two levels include the dynamism handling strategy presented in subsection $\mathrm{C}$ to detect and effectively respond to changes.

\section{A. DPb-MOPSO: Upper Level (1.)}

The upper level $\left(L_{1}\right)$ starts with a random initialization of the position of $N$ particles $P_{i}$ in swarm $S$. Each particle is a candidate solution $x_{i}^{*}$ in $n$ dimensional search space. All nondominated solutions in $L_{1}$ are stored in the leader's archive $A$. The global leader gbest is selected from $(A)$ based on the crowding distance operator between two random particles. The update of position $(X)$ and velocity $(V)$ at discrete time $t$ is done based on the best self-experience (pbest) as a local component and the global experience of all neighbors as a global component (gbest) using Equations 2 and 3.

$$
\begin{gathered}
X_{t+1}=X_{t}+V_{t+1} \\
V_{t+1}=w V_{t}+c_{1} r_{1}\left(\operatorname{pbest}(t)-X_{t}\right)+c_{2} r_{2}\left(\operatorname{gbest}(t)-X_{t}\right)
\end{gathered}
$$

where; $\mathrm{w}$ is the inertia weight, $c_{1}$ and $c_{2}$ are the acceleration coefficients. $r_{1}$ and $r_{2}$ are two random parameters designed to affect the cognitive and social components of each particle is detailed in Algorithm 1.

The detailed process of the first level $L_{1}$ is given in Figure 2 . When a successful dynamic change is detected, the lower level $\left(\mathrm{L}_{2}\right)$ switches to execute Algorithm 2 in parallel with L1.

The dynamic change detection is checked by comparing the current $P O S(t)$ with the previous $P O S(t-1)$. All changes in the DMOPs are known to the algorithm and are checked with a periodic $\tau_{t}$ as detailed in subsection C. When each DMOP has a time-dependent parameter $T$ affected by the frequency $\tau_{t}$ and is presented in Equation 4.

$$
T=\frac{1}{n_{t}}\left\lfloor\frac{\tau}{\tau_{t}}\right\rfloor
$$

where; $n_{t}$, and $\tau$ are the severity of the change and the iteration counter respectively, $\forall t \in T_{\max }$.

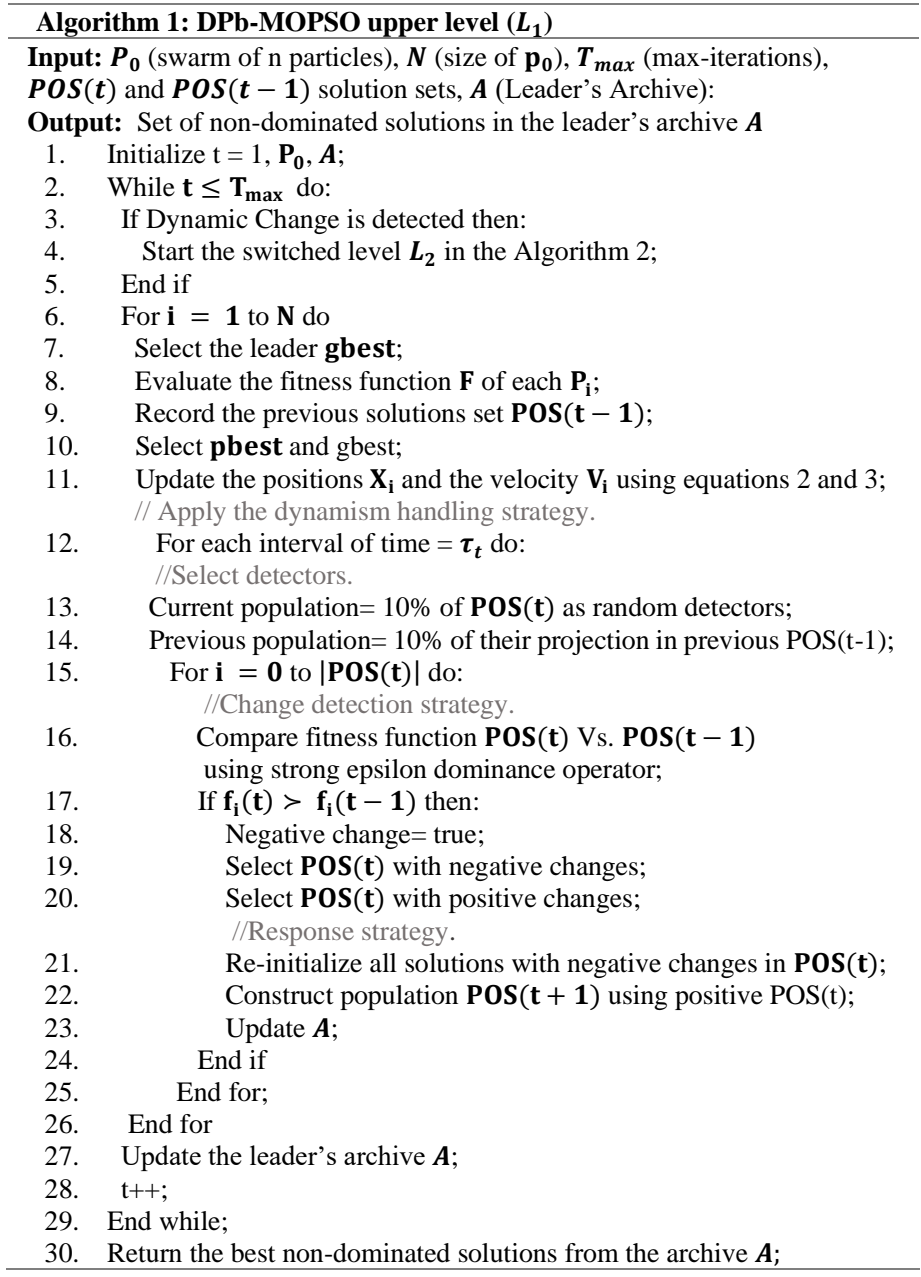




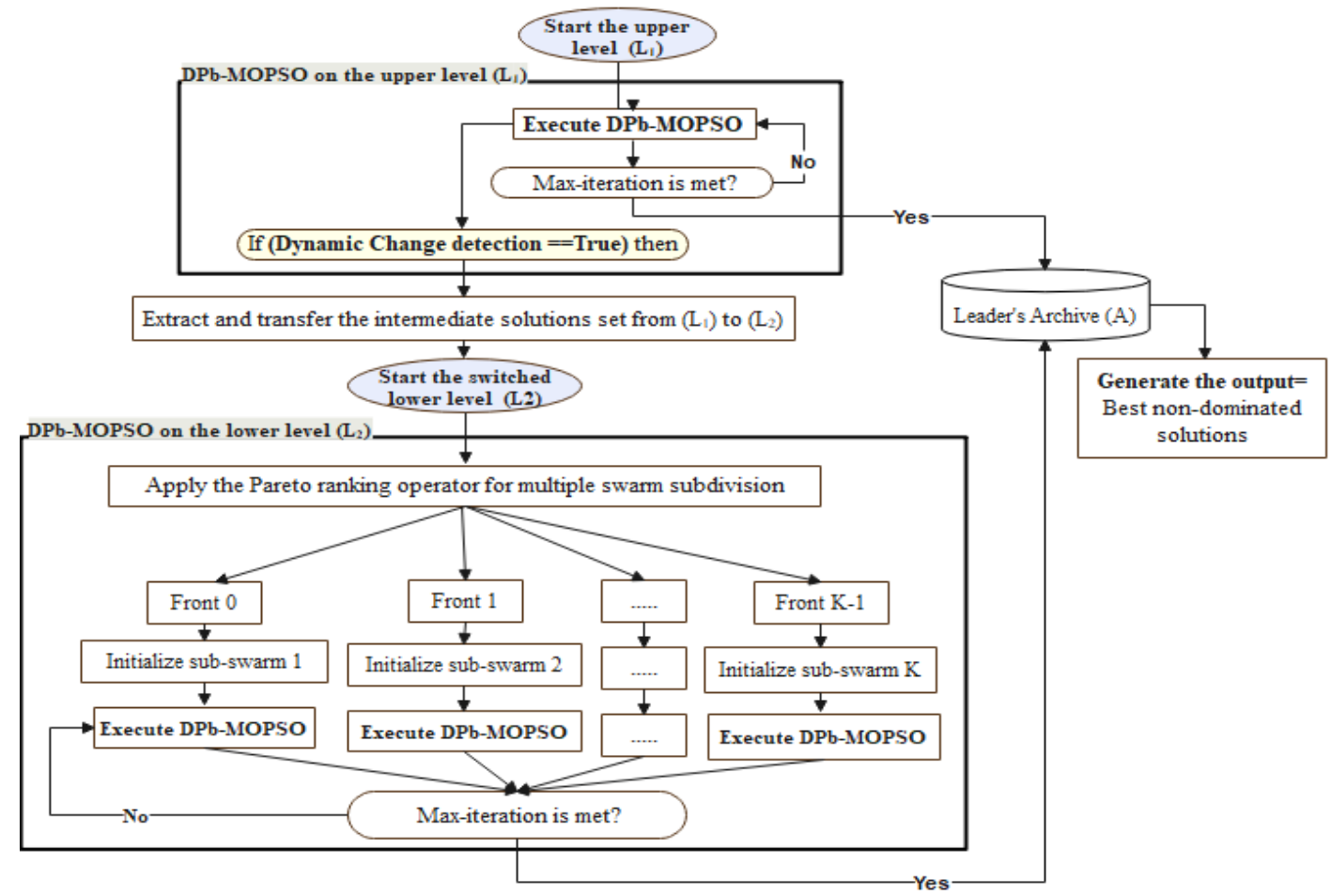

Fig. 1. The Distributed Flowchart of the Proposed Dynamic Pareto bi-level Multi-Objective Particle Swarm Optimization (DPb-MOPSO) Algorithm.

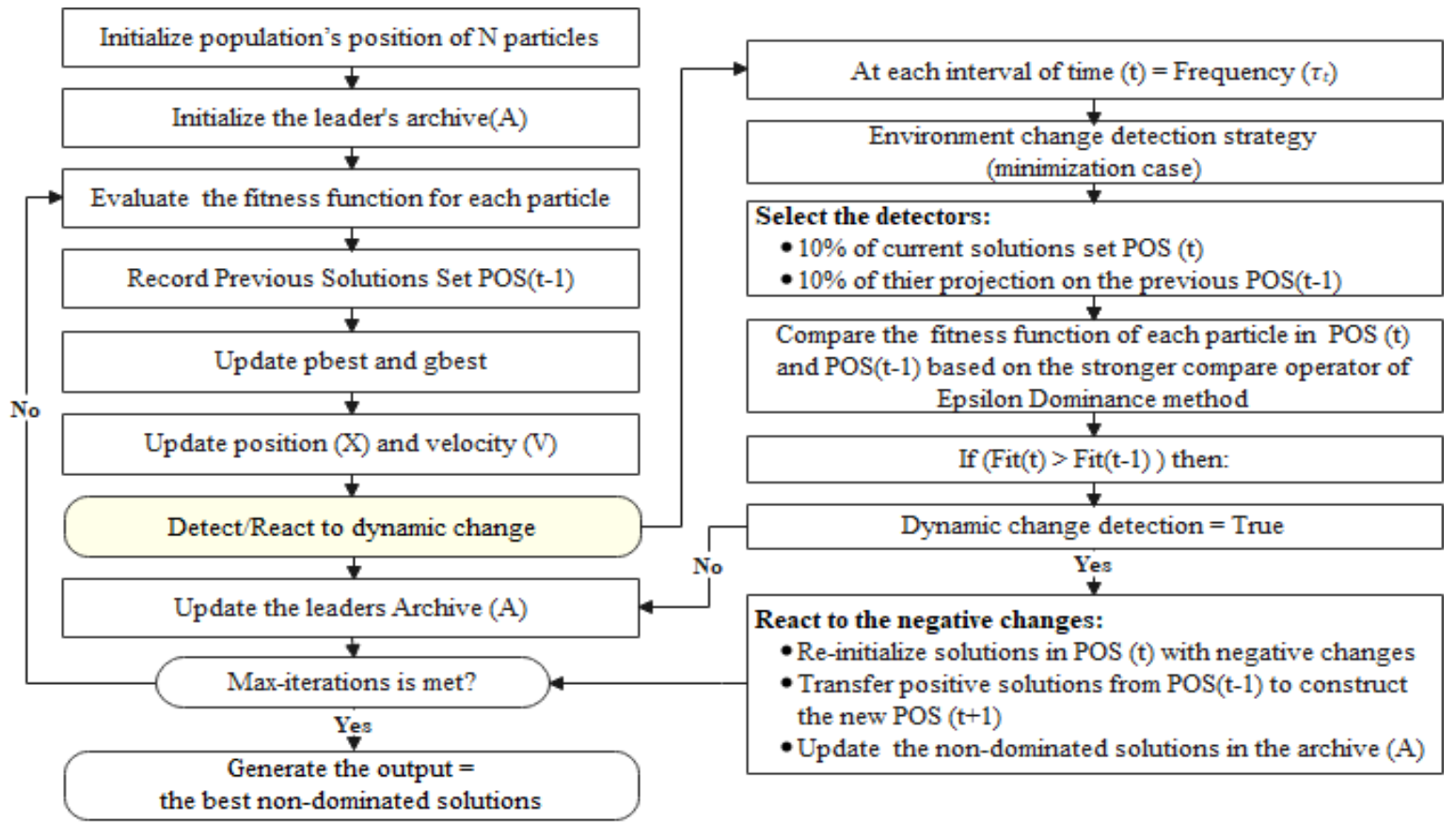

Fig. 2. The Detailed Steps of DPb-MOPSO in the Upper and Lower Levels.

In each optimization step, all the optimal solutions $x_{i}^{*}$ of $L_{1}$ are stored in archive $A$, and the epsilon operator is used to measure the best approximation to the true POF. Archive $A$ is a shared component between the two levels, used to select the best global leader (gbest).

\section{B. DPb-MOPSO: Lower Level $\left(L_{2}\right)$}

If Algorithm 1 successfully detects the first dynamic change, the lower level $\left(L_{2}\right)$ starts. The second level has a distributed architecture based on the parallel execution of multiple subswarms of the population $P^{\prime}$ transferred from $L_{1}$. Then, apply Pareto ranking operator to subdivide $\mathrm{P}^{\prime}$ into $\mathrm{K}$ sub-swarms of different sizes. The K sub-swarms are a set of fronts denoted by $\mathrm{F}_{0}, \ldots, \mathrm{F}_{\mathrm{k}-1}$. Therefore, in order to ensure equality between the front sizes, additional individuals are randomly selected from the solution set $P O S(t)$ performed in $L_{1}$ and injected into other fronts. Moreover, all sub-swarms are optimized in parallel, and perform the same process in Figure 2. The K sub-swarms are 
performed in parallel until the maximum number of iterations $\left(\mathrm{T}_{\max }\right)$. All non-dominated solutions of $L_{2}$ from $K$ sub-swarms are stored in the archive $A$. At the end of the two optimization levels, the best non-dominated solutions in archive A are generated as the output of the proposal.

\section{DPb-MOPSO: Dynamic Changes Handling Strategy}

Dynamic changes detection aims essentially to help a better search process and to prospect any interesting solutions. The two steps of dynamism handling of the proposed algorithm are listed in lines 12 to 25 in the pseudo-code of Algorithm 1, and detailed as follows:

\section{Step 1: Environment detection strategy:}

Check the environmental changes after each frequency $\tau_{t}$ is equal to 5, 10, and 20 showing severe, moderate, and slight changes respectively. All historical values of the previous population $P O S(t-1)$ and the current $P O S(t)$ are recorded at each iteration. By selecting $10 \%$ of the previous $P O S(t-1)$ as random detectors, the comparison process starts after evaluation the fitness function $\mathrm{F}$ to obtain the new optimized population. Then, select $10 \%$ of the current mapping solutions in $\operatorname{POS}(t)$ to control their evolution over time. The strong dominance operator of the Epsilon-Dominance method is used to compare the time-varying behavior of each particle between $t$ and $t-1$. For all $M$ objectives, if $X_{t}$ is strictly better than $X_{t-1},\left(X_{t}>X_{t-1}\right)$, then the solution $X_{t}$ strongly dominates the solution $X_{t-1}$.

\section{$\checkmark$ Step 2: Response change strategy:}

If the change is successfully identified, all solutions $P O S(t)$ with negative changes are reinitialized. In order to assume that only solutions with positive effects have good diversity and convergence, all detectors with positive changes $\operatorname{POS}(t)$ are transferred to build a new population at $t+1$. In addition, reassess the leader's profile $(A)$ to update all non-dominant solutions and overcome the deterioration of research capabilities.

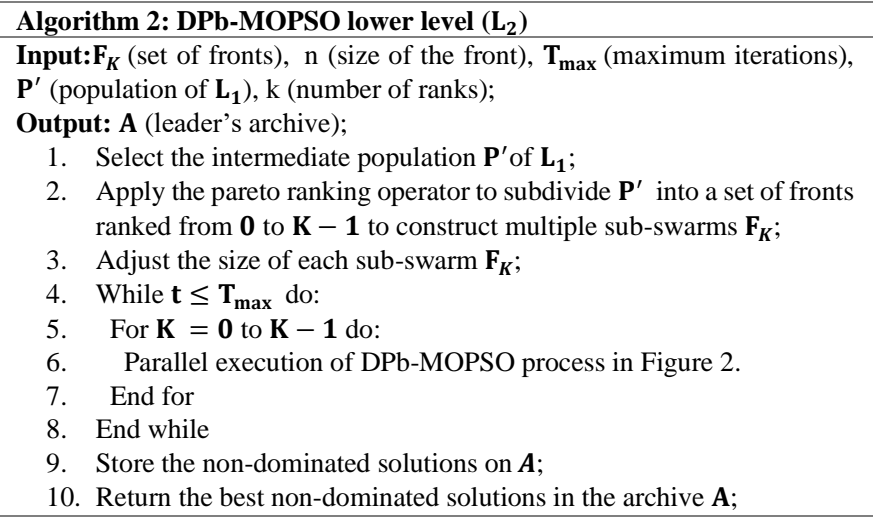

\section{EXPERIMENTAL STUDY: PRELIMINARIES}

This section presents the empirical study referring to the contributions [13] and [19]. The proposed DPb-MOPSO approach is compared to six transfer learning-based methods [13], five MOEAs [19], and four MOPSO-based approaches [9]
, [12], [14], [20]. In the following experimentations algorithms are executed during 30 independent runs. Each run is executed during the maximum number of iterations $T_{\max }=3 \times n_{t} \times$ $\tau_{t}+50$, where; $\tau_{t}$ is the frequency of change fixed to 5,10 and 20 respectively, and $n_{t}$ is the severity of the change fixed to 10 . The Java implementation of the proposed method is done using the jMETAL framework [33] on a personal computer with 8 Go of Ram, 1 To, and a i7 intel processor. Experimental settings are summarized in Table II.

TABLE II. PARAMETERS SETTINGS OF MOEAs.

\begin{tabular}{|c|c|c|}
\hline \multicolumn{2}{|c|}{ MOPSO, dMOPSO, pbMOPSO, Dynamic-MOPSO and DPb-MOPSO } \\
\hline $\begin{array}{c}\text { Perturbation } \\
\text { index }=1.0\end{array}$ & $\begin{array}{c}\text { Mutation } \\
\text { probability }= \\
1.0 / \text { number of } \\
\text { variables }\end{array}$ & $\begin{array}{c}\mathrm{r} 1 \text { and } \mathrm{r} 2=\text { rand }() \\
\mathrm{c} 1 \text { and } \mathrm{c} 2=\text { rand }(1.5,2.0) \\
\mathrm{w}=\text { rand }(0.1,0.5)\end{array}$ \\
\hline \multicolumn{2}{|c|}{ dCOEA, PPS, MOEAD, SGEA, DNSGA-II, TL-methods } \\
\hline $\begin{array}{c}\text { Crossover } \\
\text { probability=1.0 }\end{array}$ & $\begin{array}{c}\text { Mutation } \\
\text { distribution= }=20\end{array}$ & Crossover distribution $=20$ \\
\hline \multicolumn{3}{|c|}{ Common parameters for all algorithms } \\
\hline $\begin{array}{c}\text { Swarm } \\
\text { size }=100\end{array}$ & Archive size $=100$ & Max-iterations $=3 \times n_{t} \times \tau_{t}+50$ \\
\hline
\end{tabular}

\section{A. Dynamic Multi Objective Benchmarks}

This study concerns 21 benchmarks which are made of: five FDA [1], three dMOP [16], six F(ZJZ) [17], and seven UDF [24] functions. Table III lists all DMOPs parameter settings and the dynamic nature of POS and POF.

\section{B. Quality Indicators:}

Three quality indicators are considered for convergence and diversity measurement, and therefore include IGD, MIGD, and HVD metrics. The small value is the best.

- IGD is calculated using Equation 5 to measure the minimum Euclidean distance $d$ between ith points in the generate $P O F$ and the true $P O F^{*}$.

$$
I G D\left(P^{*} F^{*}, P O F\right)=\frac{\sum_{i \in P O F^{*}} d(i, P O F)}{\left|P O F^{*}\right|}
$$

- MIGD is the average of the IGD values computed using Equation 6.

$$
\operatorname{MIGD}\left(\mathrm{POF}_{t}^{*}, \mathrm{POF}_{t}\right)=\frac{1}{T} \sum_{t \in T} I G D\left(P O F_{t}^{*}, P O F_{t}\right)
$$

- The HVD indicator is designed to measure the difference hypervolume between the obtained $P O F^{*}$ to the true $P O F^{*}$ and presented in equation 7.

$$
H V D=H V\left(P O F_{t}^{*}\right)-H V\left(P O F_{t}\right)
$$

\section{EXPERIMENTAL STUDY:}

\section{RESULTS AND STATISTICAL ANALYSIS}

This section aims to analyse the quantitative results of IGD, MIGD and HVD indicators. All mean and standard deviation values are reported in the appendix (see Tables VII-X). Important values are highlighted in bold and gray. The inferential statistical concept of Friedman's two-way Analysis of Variance (ANOVA) method is used to determine the significance level between all tested MOEAs. 
TABLE III Characteristics and Parameter Settings of DMOPs

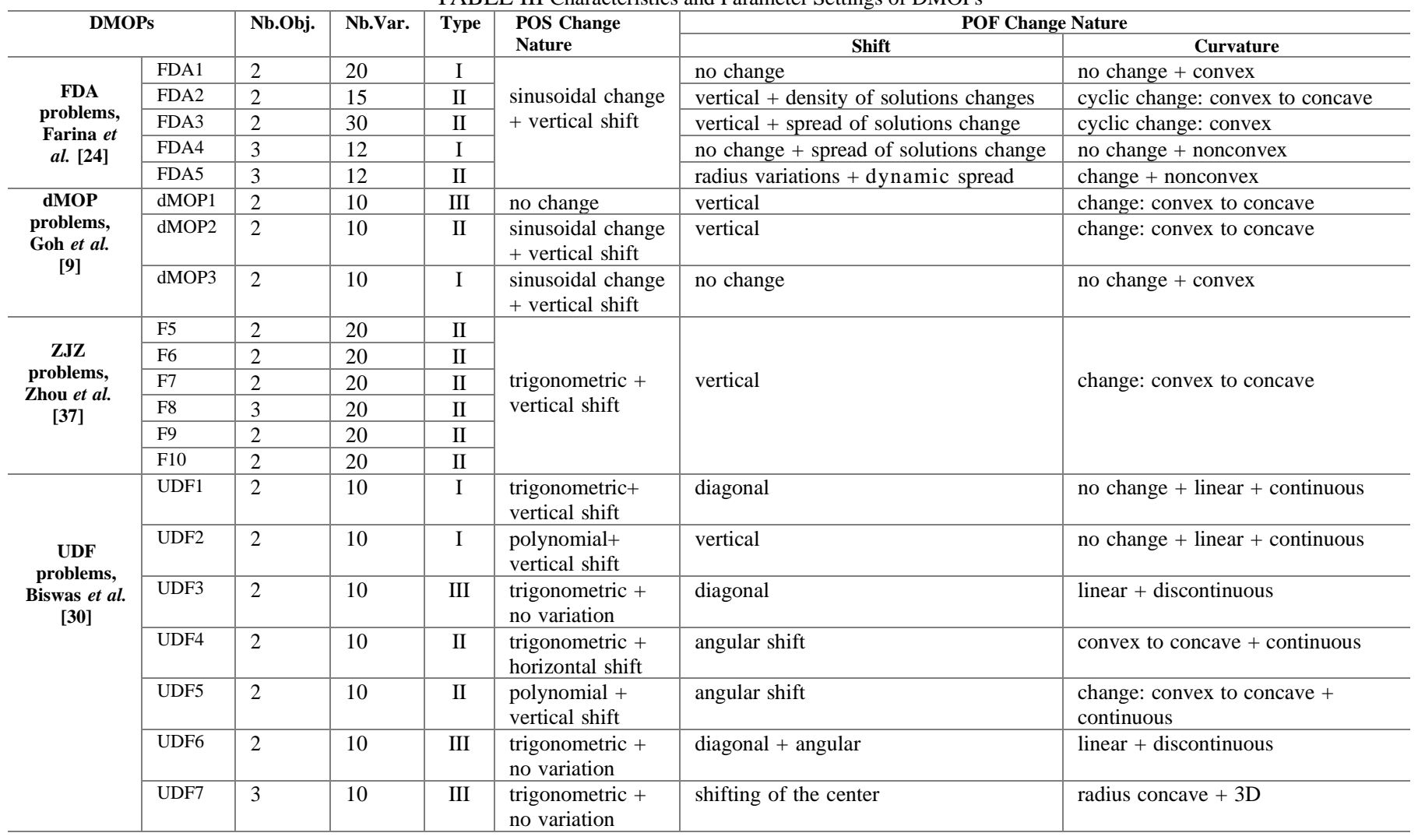

\section{A. Results Analysis through Mean and Standard Deviation}

Different configurations were considered on MOEAs to demonstrate the impact of changing frequency when solving DMOPs. These configurations are implemented for severe, moderate, and slight changes based on the constant value of the severity of change $\mathrm{n}_{\mathrm{t}}$ and the variation of the frequency $\tau_{\mathrm{t}}$.

1) Results on UDF and F(ZJZ) Problems

Experimental results in Table VII show that DPb-MOPSO is better than DNSGA-II, dCOEA, PPS, MOEA/D, SGEA, MOPSO, dMOPSO, pbMOPSO for solving the majority of UDF and F(ZJZ) functions on both IGD and HVD metrics. The 13 functions are classified as follows: type I (UDF1, UDF2), type II (F5-F10, UDF4, UDF5), and type III (UDF3, UDF6, UDF7). In order to show statistically reliable conclusion, we use boxplots of the one-way ANOVA test in Figure 3. We can conclude that, compared with Dynamic-MOPSO, DPbMOPSO is a competitive system with the best convergence on IGD and the best distribution on HVD. In detail, the best result of DPb-MOPSO on IGD are 8/13 (UDF1, UDF2, UDF4, UDF5, UDF6, F5, F6, F8) and 7/13 (UDF1, UDF2, UDF4, UDF5, UDF6, F6, F8) are on HVD, while Dynamic-MOPSO is $3 / 13$ (F7, F9, F10) on IGD and 5/13 (F5, F7, F9, F10, UDF7) on HVD. When solving UDF3 on HVD and UDF7 on IGD, there is a slight difference between DPb-MOPSO and pbMOPSO. Compared with the dMOPSO system, DPb-MOPSO only has poor convergence for the UDF3 function on the IGD measurement.

\section{2) Results on FDA and dMOP Problems}

In the case of 8 FDA and dMOP functions, all quantitative results of MIGD, IGD and HVD indicators are reported in
Tables VIII, IX, X respectively with severe, moderate and slight changes. In order to facilitate the analysis of the results, the boxplots of the one-way ANOVA test are considered in Figures 4 , 5, and 6. In this part of the study, 8 FDA and dMOP benchmarks were tested. Most FDA and dMOP functions belong to type I (FDA1, FDA4, dMOP3) or types II (FDA2, FDA3, FDA5, dMOP2), and only dMOP1 belongs to type III. The one-way ANOVA results in Figure 4 determine the importance of DPb-MOPSO compared with MMTL-MOEAD,

KF-MOEAD, PPS-MOEAD, SVR-MOEAD, Tr-MOEAD, RI-MOEAD, MOPSO, dMOPSO, pbMOPSO and DynamicMOPSO to solve 8 DMOPs through MIGD metric. Figure 5 and Figure 6 have shown the boxplots of the one-way ANOVA test of the IGD and the HVD quality indicators.

Compared with DNSGA-II, dCOEA, PPS, MOEA/D, SGEA, MOPSO, dMOPSO, and pbMOPSO, the DPb-MOPSO method is the best to solve 4/8 (FDA2, FDA4, FDA5, dMOP1), 5/8 (FDA2, FDA3, FDA4, FDA5, dMOP1), and 5/8 (FDA1, FDA3, FDA4, FDA5, dMOP1) respectively in the MIGD indicator of severe, moderate and slight environmental changes. MOPSO, Dynamic-MOPSO and MMLT-MOEAD only have good results when solving 2/8 (FDA1, dMOP2), 1/8 (FDA3) and 1/8 (dMOP3) respectively on the MIGD with severe environmental changes. However, MOPSO, dMOPSO and MMLT-MOEAD only have the best mean values for FDA1, dMOP2 and dMOP3 on the MIGD with moderate changes. For slightly change, Dynamic-MOPSO, dMOPSO and MMTL-MOEAD are the best choices for FDA2, dMOP2 and dMOP3 respectively. Using IGD metric with severe changes, DPb-MOPSO aims to solve 4/8 (FDA2, FDA3, FDA4, dMOP1), MOPSO has 1/8 (FDA1), pbMOPSO has 2/8 (FDA5, dMOP2) and dCOEA has 
1/8 (dMOP3). For moderate changes, we can conclude that $4 / 8$ (FDA3, FDA4, FDA5, dMOP3) functions are resolved using DPb-MOPSO, 1/8 (FDA1) uses MOPSO, 1/8 (FDA2) uses DNSGA-II, 1/8 (dMOP2) uses pbMOPSO and 1/8 (dMOP3) uses dCOEA. For slight changes, we can find 4/8 (FDA3, FDA4, FDA5, dMOP3) benchmarks are resolved using DPbMOPSO, 2/8 (FDA1, FDA2) use MOPSO, 1/8 (dMOP2) use pbMOPSO and 1/8 (dMOP3) use dCOEA. Compared with MOPSO which aims to solve 1/8 (FDA1), SGEA 1/8 (FDA2), pbMOPSO 1/8 (dMOP2) and dCOEA 1/8 (dMOP3), the DPbMOPSO system can solve 4/8 (FDA3, FDA4, FDA5, dMOP1) functions for the 3 kinds of environmental changes using HVD.

\section{B. Discussion through Friedman two-way ANOVA Test}

The use of the mean and standard deviation values of the quality indicators indicates that they are insufficient to evaluate the performance of swarm intelligence algorithms and highlight their significance level. For this reason, Friedman's two-way ANOVA ranking test and its Post-hoc procedure [34] are used to analyze the results of different environmental changes on IGD, MIGD and HVD. Friedman's two-way ANOVA test is a non-parametric alternative to repeated-measures ANOVA. The test does not assume a normal distribution to compare multiple treatments and determine the level of significance between algorithms. First, define the null hypothesis $H_{0}: \mu_{1}=\mu_{i}$ (there is no difference between the means), and the alternative hypothesis $H_{1}: \mu_{1} \neq \mu_{i}$ (there is a difference).

If the P-value $\leq \alpha$ indicates the statistical significance level, then reject the null hypothesis, otherwise we accept $H_{1}$, where Alpha $(\alpha)$ is equal to 0.05 . Friedman's two-way ANOVA ranking is calculated by assigning a ranking value $\left(r_{i}\right)$ to each algorithm $i$ while; 1 is the best result to $\mathrm{k}$, and $\mathrm{k}$ is the worst result. For a tie case, we assign the average of the rankings. The decision rule is defined as the critical value (CV) determined according to the chi-Square $\left(\chi^{2}\right)$ table $^{1}$. The $\mathrm{CV}$ value is fixed according to the degree of freedom (df) equal to $\mathrm{k}-1$, where $\mathrm{k}$ is the number of comparison algorithms and $\alpha=0.05$. If the calculated $\chi^{2}$ is greater than $\mathrm{CV}$, we will reject the null hypothesis. In addition, if the calculated P-value is less than 0.05 , we assume that there is a significant difference between the test algorithms.

\section{1) Friedman rankings test}

According to Tables IV and V, we can conclude that $\mathrm{DPb}$ MOPSO is a winner in using IGD to measure FDA, dMOP functions for severe and slight environmental changes. However, when using the IGD, HVD, and MIGD quality indicators, it ranks higher in addressing the moderate environmental changes of 21 DMOPs (FDA, dMOP, UDF, and ZJZ (F)). Whereas, assuming that the overall statistical difference between all tested algorithms is significant, all calculated $\chi^{2}$ are greater than CV. At the 0.05 level of significance, all means are not equal. Almost, most P-values less than 0.05 represent the assumption of rejecting the null hypothesis and assuming that some means are not exactly equal and there are significant differences. Furthermore, the null hypothesis that there is no difference between means is retained for slight changes using the HVD indicator with a P- value $=0.207$, which is greater than 0.05 . Friedman's ranking test detected significant difference between multiple comparisons. However, it is difficult to determine which group pairs are significantly different. Therefore, Friedman $1 \times \mathrm{N}$ ANOVA multiple comparisons were considered for the results discussion, aiming to compare DPb-MOPSO as a control method with other MOEAs.

TABLE IV. Friedman's ANOVA Mean Ranks on IGD and HVD for FDA, dMOP, F (ZJZ) and UDF.

\begin{tabular}{|c|c|c|c|c|c|c|}
\hline \multicolumn{7}{|c|}{ Mean Ranks over IGD and HVD } \\
\hline Dynamic changes & \multicolumn{2}{|c|}{$\begin{array}{c}\text { Severe } \\
\left(\tau_{\mathrm{t}}=5, \mathrm{n}_{\mathrm{t}}=10\right)\end{array}$} & \multicolumn{2}{|c|}{$\begin{array}{c}\text { Moderate } \\
\left(\tau_{\mathrm{t}}=10, \mathrm{n}_{\mathrm{t}}=10\right)\end{array}$} & \multicolumn{2}{|c|}{$\begin{array}{c}\text { Slight } \\
\left(\tau_{\mathrm{t}}=20, \mathrm{n}_{\mathrm{t}}=10\right)\end{array}$} \\
\hline$\overline{\text { DMOPs }}$ & \multicolumn{2}{|c|}{ FDA, dMOP } & \multicolumn{2}{|c|}{$\begin{array}{l}\text { FDA, dMOP, F(ZJZ), } \\
\text { UDF }\end{array}$} & \multicolumn{2}{|c|}{ FDA, dMOP } \\
\hline QI & IGD & HVD & IGD & HVD & IGD & HVD \\
\hline DNSGA-II & 8.94 & 7.25 & 7.29 & 6.40 & 8.25 & 6.00 \\
\hline $\mathrm{dCOEA}$ & 6.44 & 5.38 & 7.98 & 6.52 & 7.00 & 6.50 \\
\hline PPS & 8.00 & 7.25 & 7.19 & 6.12 & 8.00 & 6.00 \\
\hline MOEA/D & 8.38 & 7.75 & 7.74 & 6.79 & 7.38 & 6.88 \\
\hline SGEA & 6.13 & 4.25 & 6.10 & 4.40 & 5.13 & 4.25 \\
\hline MOPSO & 3.63 & 5.94 & 5.40 & 7.29 & 3.19 & 6.06 \\
\hline dMOPSO & 5.50 & 6.38 & 6.31 & 7.40 & 5.31 & 6.81 \\
\hline pbMOPSO & 2.63 & 4.00 & 3.21 & 4.45 & 5.00 & 5.00 \\
\hline Dynamic-MOPSO & 3.25 & 3.63 & 1.95 & 2.83 & 3.25 & 4.25 \\
\hline DPb-MOPSO & 2.13 & 3.19 & 1.83 & 2.79 & 2.50 & 3.25 \\
\hline Chi-Square $\chi^{2}$ & 48.77 & 21.69 & 113.70 & 63.19 & 34.42 & 12.11 \\
\hline P-value $(\boldsymbol{\alpha}=\mathbf{0 . 0 5})$ & $1.9 \mathrm{E}-7$ & 0.01 & $2.6 \mathrm{E}-2$ & 3.3E-1 & $8.0 \mathrm{E}-5$ & 0.21 \\
\hline Statistically Significant & Yes & Yes & Yes & Yes & Yes & No \\
\hline Critical value & \multicolumn{6}{|c|}{16.92} \\
\hline df & \multicolumn{6}{|c|}{9} \\
\hline
\end{tabular}

TABLE V. Friedman's ANOVA Mean Ranks on MIGD for FDA, dMOP.

\begin{tabular}{|c|c|c|c|}
\hline \multicolumn{4}{|c|}{ Mean Ranks over MIGD } \\
\hline DMOPs & & FDA, dMOP & \\
\hline Dynamic changes & $\begin{array}{c}\text { Severe } \\
\left(\tau_{\mathrm{t}}=5, \mathrm{n}_{\mathrm{t}}=10\right)\end{array}$ & $\begin{array}{c}\text { Moderate } \\
\left(\tau_{\mathrm{t}}=10, \mathrm{n}_{\mathrm{t}}=10\right)\end{array}$ & $\begin{array}{c}\text { Slight } \\
\left(\tau_{\mathrm{t}}=20, \mathrm{n}_{\mathrm{t}}=10\right)\end{array}$ \\
\hline MMTL-MOEA/D & 5.63 & 5.50 & 5.50 \\
\hline KF-MOEA/D & 9.13 & 8.63 & 7.88 \\
\hline PPS-MOEA/D & 8.00 & 7.25 & 8.13 \\
\hline SVR-MOEA/D & 8.50 & 8.00 & 8.13 \\
\hline Tr-MOEA/D & 9.00 & 8.88 & 8.88 \\
\hline RI-MOEA/D & 8.88 & 9.13 & 8.38 \\
\hline MOPSO & 3.19 & 4.13 & 4.19 \\
\hline dMOPSO & 4.56 & 6.13 & 5.06 \\
\hline pbMOPSO & 3.00 & 3.50 & 4.38 \\
\hline Dynamic-MOPSO & 3.75 & 2.88 & 3.00 \\
\hline DPb-MOPSO & 2.38 & 2.00 & 2.50 \\
\hline Chi-Square $\chi^{2}$ & 54.29 & 48.21 & 39.85 \\
\hline P-value $(\boldsymbol{\alpha}=\mathbf{0 . 0 5})$ & $4.29 \mathrm{E}-8$ & $5.69 \mathrm{E}-7$ & $1.80 \mathrm{E}-5$ \\
\hline Statistically Significant & Yes & Yes & Yes \\
\hline Critical value & & 18.31 & \\
\hline df & & 10 & \\
\hline
\end{tabular}

\section{2) Friedman $1 \times N$ ANOVA Test}

The Freidman Post-hoc procedure was performed to compare group means, and DPb-MOPSO was the control method. The Freidman Post-hoc procedure process results in a P-value (PV) at the 0.05 significance level that determines the degree of rejection of the null hypothesis. In Table VI, we first consider the PV over MIGD metric and compare DPb-MOPSO with six methods based on transfer learning and four methods based on MOPSO. Note that the sign (+) means that DPb-MOPSO is the best algorithm, and $(\cong)$ the same significant level is determined. Compared with KF-MOEA/D, Tr-MOEA/D, RI-MOEA/D, SVR-MOEA/D, PPS-MOEA/D and MMTL-MOEA/D, the importance of the DPb-MOPSO system can be observed with $\mathrm{P}$-values of all environment changes are all less than 0.05 .

However, it has the same level of significance compared with MOPSO, pbMOPSO and Dynamic-MOPSO. In addition, we only retained the null hypothesis of the dMOPSO system on moderate changes, and compared with DPb-MOPSO, it has the same significance for severe and slight changes and MMTL-

${ }^{1}$ http://uregina.ca/ gingrich/appchi.pdf. 
MOEA/D with slight changes. The PV over IGD presents the significant difference of DPb-MOPSO compared to DNSGAII, MOEA/D, PPS, and dCOEA for all the types of changes. In addition, we can infer that there is no difference in p-value greater than 0.05 , for severe and slight changes between $\mathrm{DPb}$ MOPSO compared with dMOPSO, MOPSO, pbMOPSO and Dynamic-MOPSO.

Also, DPb-MOPSO has significant result for moderate changes compared to six MOEAs. Furthermore, the computed P-values on HVD metric are greater than 0.05 , we retain the null hypothesis of no difference between mean values for the six MOEAs with slight changes. However, the DPb-MOPSO system performs six MOEAs (DNSGA-II, MOEA/D, PPS, dCOEA, dMOPSO, MOPSO) in solving DMOPs with moderate changes except for the SGEA, pbMOPSO and Dynamic-MOPSO approaches have the same importance as the proposal.

TABLE VI. P-values obtained by the post hoc method over the results of Friedman procedure with $\alpha=0.05$ over MIGD, IGD and HVD

\begin{tabular}{|c|c|c|c|c|}
\hline \multirow[b]{2}{*}{ QI } & \multirow[b]{2}{*}{ DPb-MOPSO vs. } & \multicolumn{3}{|c|}{$\left(\boldsymbol{\tau}_{t}, \boldsymbol{n}_{t}\right)$} \\
\hline & & $(5,10)$ & $(10,10)$ & $(20,10)$ \\
\hline \multirow{10}{*}{ MIGD } & KF-MOEA/D & $\leq 0.001+$ & $\leq 0.001+$ & $0.001+$ \\
\hline & Tr-MOEA/D & $\leq 0.001+$ & $\leq 0.001+$ & $\leq 0.001+$ \\
\hline & RI-MOEA/D & $\leq 0.001+$ & $\leq 0.001+$ & $\leq 0.001+$ \\
\hline & SVR-MOEA/D & $\leq 0.001+$ & $\leq 0.001+$ & $0.001+$ \\
\hline & PPS-MOEA/D & $0.001+$ & $0.002+$ & $0.001+$ \\
\hline & MMTL-MOEA/D & $0.050+$ & $0.035+$ & $0.070 \cong$ \\
\hline & dMOPSO & $0.187 \cong$ & $0.013+$ & $0.122 \cong$ \\
\hline & MOPSO & $0.624 \cong$ & $0.200 \cong$ & $0.309 \cong$ \\
\hline & pbMOPSO & $0.706 \cong$ & $0.366 \cong$ & $0.258 \cong$ \\
\hline & Dynamic-MOPSO & $0.407 \cong$ & $0.598 \cong$ & $0.763 \cong$ \\
\hline \multirow{9}{*}{ IGD } & DNSGA-II & $\leq 0.001+$ & $\leq 0.001+$ & $\leq 0.001+$ \\
\hline & MOEA/D & $\leq 0.001+$ & $\leq 0.001+$ & $0.001+$ \\
\hline & PPS & $\leq 0.001+$ & $\leq 0.001+$ & $\leq 0.001+$ \\
\hline & dCOEA & $0.004+$ & $\leq 0.001+$ & $0.003+$ \\
\hline & SGEA & $0.008+$ & $\leq 0.001+$ & $0.083 \cong$ \\
\hline & dMOPSO & $\mathbf{0 . 0 2 6}+$ & $\leq 0.001+$ & $0.063 \cong$ \\
\hline & MOPSO & $0.322 \cong$ & $\leq 0.001+$ & $0.650 \cong$ \\
\hline & pbMOPSO & $0.741 \cong$ & $0.139 \cong$ & $0.099 \cong$ \\
\hline & Dynamic-MOPSO & $0.457 \cong$ & $0.899 \cong$ & $0.620 \cong$ \\
\hline \multirow{9}{*}{ HVD } & DNSGA-II & $0.007+$ & $\leq 0.001+$ & \multirow{9}{*}{$\begin{array}{l}\text { The Freidman } \\
\text { test retained the } \\
\text { null hypothesis } \\
\text { of no difference } \\
\text { between mean } \\
\text { values with P- } \\
\text { value }=0.207> \\
0.05 \text {. }\end{array}$} \\
\hline & MOEA/D & $0.003+$ & $\leq 0.001+$ & \\
\hline & PPS & $0.007+$ & $\leq \mathbf{0 . 0 0 1 +}$ & \\
\hline & dCOEA & $0.148 \cong$ & $\leq \mathbf{0 . 0 0 1 +}$ & \\
\hline & SGEA & $0.483 \cong$ & $0.083 \cong$ & \\
\hline & dMOPSO & $\mathbf{0 . 0 3 5}+$ & $\leq 0.001+$ & \\
\hline & MOPSO & $0.069 \cong$ & $\leq 0.001+$ & \\
\hline & pbMOPSO & $0.591 \cong$ & $0.074 \cong$ & \\
\hline & Dynamic-MOPSO & $0.773 \cong$ & $0.959 \cong$ & \\
\hline
\end{tabular}

+: DPb-MOPSO is the best algorithm, $\cong:$ DPb-MOPSO has the same significant level compared to other MOEAs (significance level is 0.05 ).

In conclusion, and in regards to the state-of-the-art methods, the proposed DPb-MOPSO has shown its importance compared with other MOPSO-based methods. In addition, compared with the new DPb-MOPSO, the MOPSO-based system is the most competitive. But they failed to resolve multiple DMOPs, thus demonstrating the utility and importance of using dynamic processing strategies for two-stage optimization to detect and effectively respond to changes. However, the DPb-MOPSO algorithm also failed in some test problems with the characteristics of time-varying spread, dynamic density of the solution, shifting of the center point and a discontinuous POF. the DPb-MOPSO may requires an additional mechanism to detect the dynamic density of the POS and effectively respond to it and assume good distribution using the HVD measurement.
One-way ANOVA Results in a Boxplot of 10 MOEAs on IGD for UDF, ZJZ(F) with

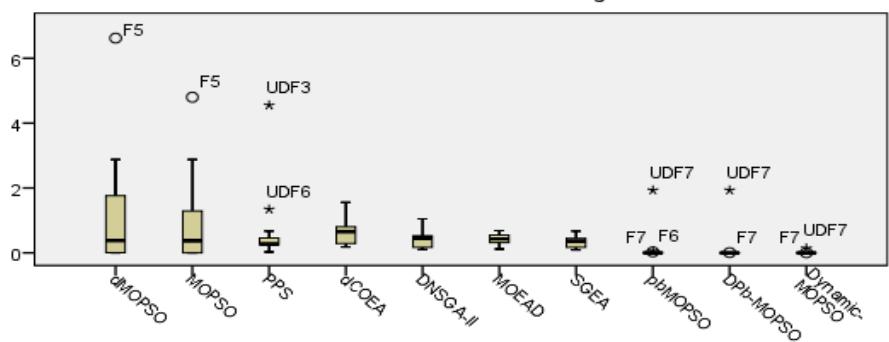

(a)

One-way ANOVA Results in a Boxplot of 10 MOEAs on HVD for UDF, ZJZ (F) with Moderate Environmental Changes.

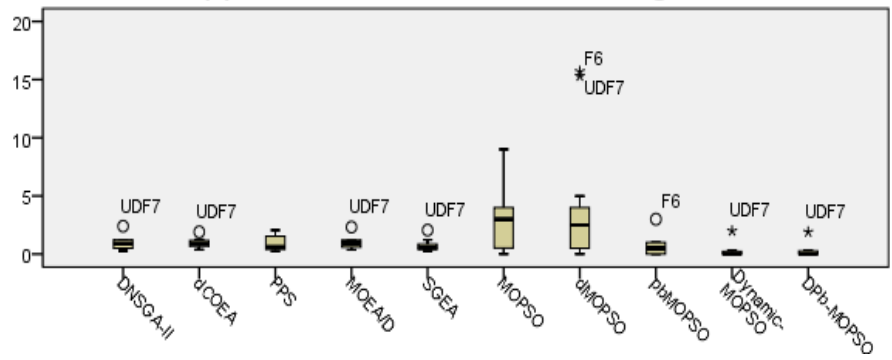

(b)

Fig. 3. ANOVA Boxplot on (a) IGD and (b) HVD with Moderate Environmental Changes for UDF and F(ZJZ) functions.

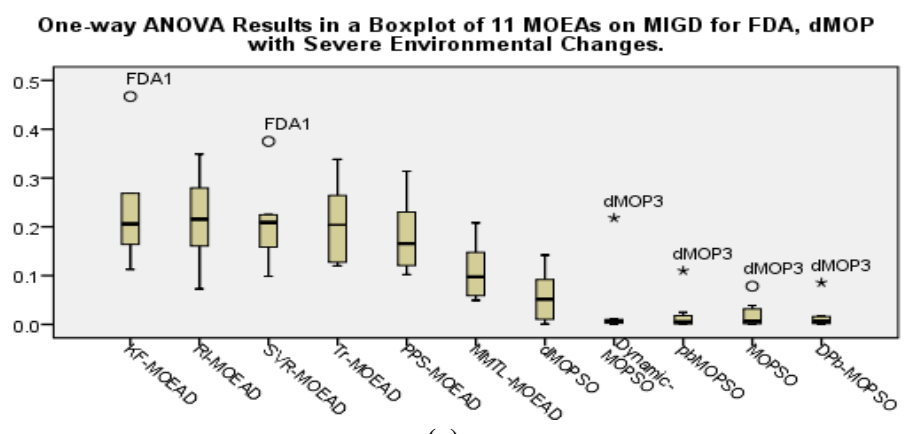

(a)

One-way ANOVA Results in a Boxplot of 11 MOEAs on MIGD for FDA, dMOP with Moderate

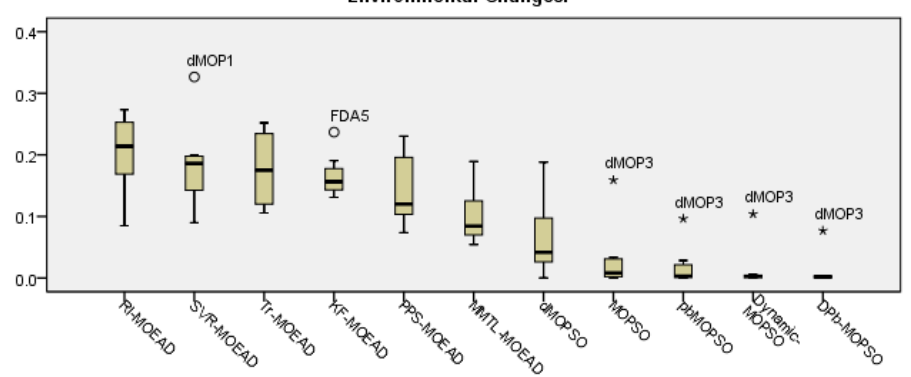

(b)

One-way ANOVA Results in a Boxplot of 11 MOEAs on MIGD for FDA, dMOP with Slight

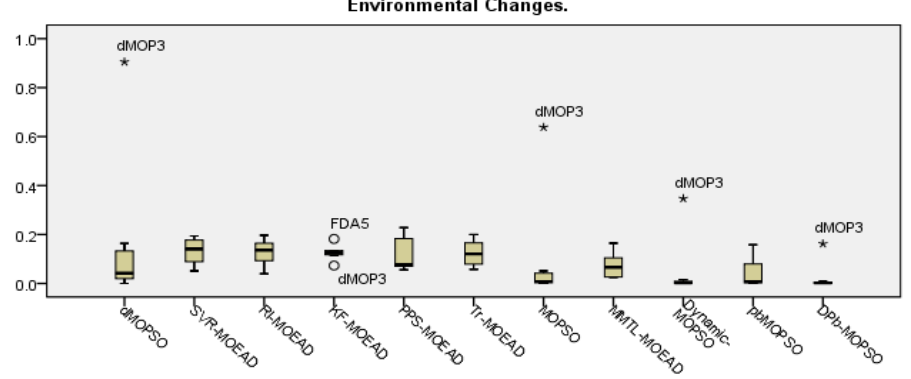

(c)

Fig. 4. ANOVA Multiple Comparison on MIGD with (a) Severe, (b) Moderate, and (c) Slight Environmental Changes for FDA and dMOP functions. 
One-way ANOVA Results in a Boxplot of 10 MOEAs on IGD for FDA, dMOP with Severe

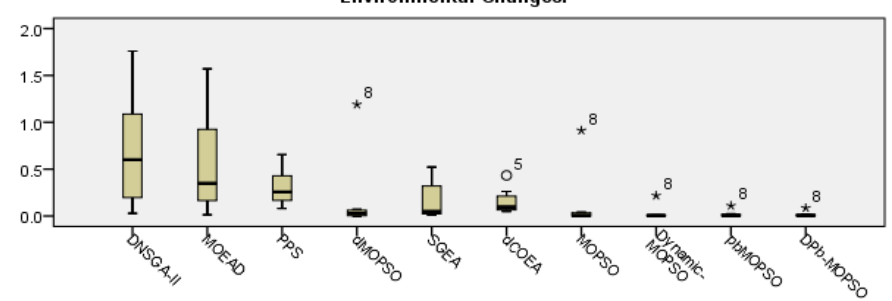

(a) One-way ANOVA Results in a Boxplot of 10 MOEAs on IGD for FDA, dMOP with Moderate
Environmental Changes.

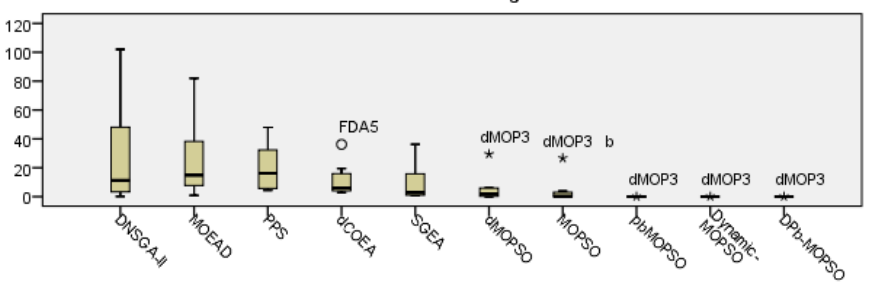

(b)

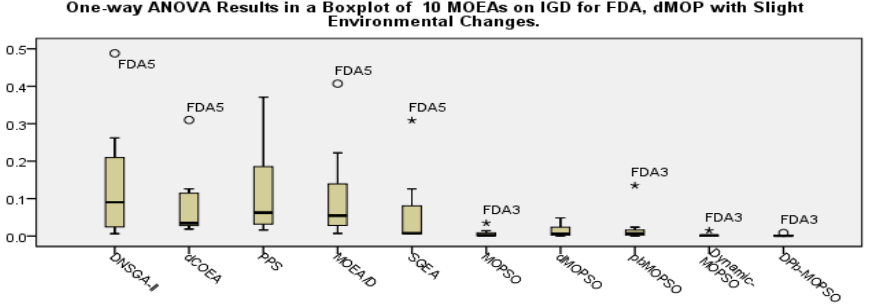

(c)

Fig. 5. ANOVA Multiple Comparison on IGD with (a) Severe, (b) Moderate, and (c) Slight Environmental Changes for FDA and dMOP functions

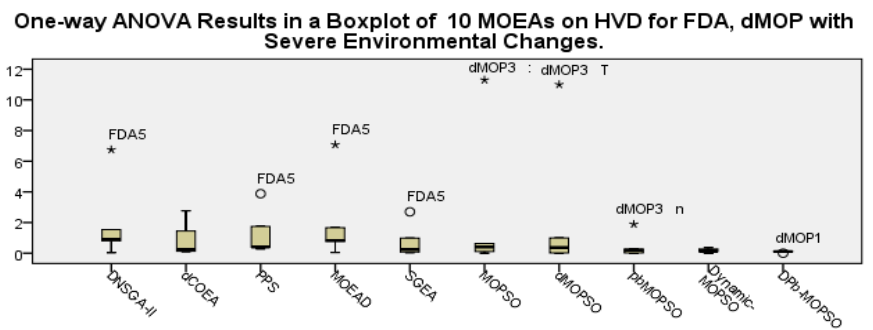

(a)

One-way ANOVA Results in a Boxplot of 10 MOEAs on HVD for FDA, dMOP with

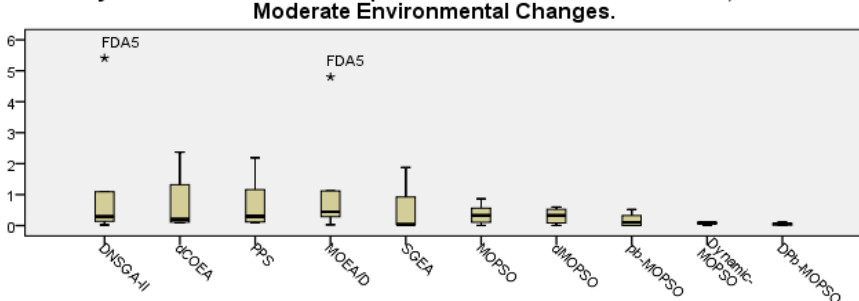

(b)

One-way ANOVA Results in a Boxplot of 10 MOEAs on HVD for FDA, dMOP with

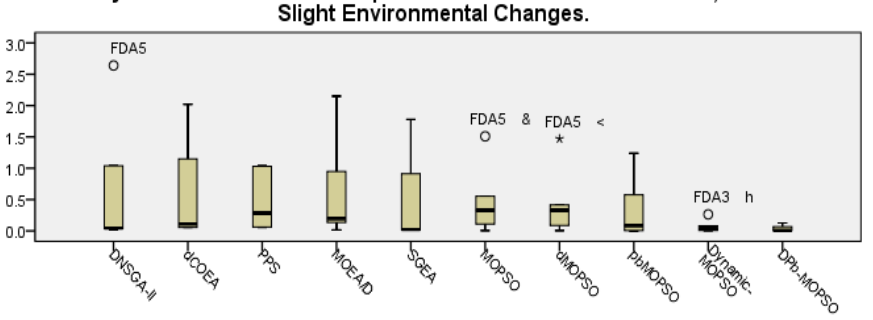

(c)

Fig. 6. ANOVA Multiple Comparison on HVD with (a) Severe, (b) Moderate, and (c) Slight Environmental Changes for FDA and dMOP functions.

\section{STABILITY ANALYSIS USING LYAPUNOV THEOREM}

The stability analysis is an important aspect of analyzing the robustness of dynamic systems. The Lyapunov theorem proposed by Alexandr Mikhailovich Lyapunov [35] is a wellknown stability analysis mechanism. The theorem aims to measure the growth of the initial values over time, and the small differences from one instance to another is called the Lyapunov Exponent (LE). In addition, LE can grow to a very large differences to indicate the speed at which two initially close dynamics diverge or converge. A positive value of LE indicates divergence, while a negative value indicates convergence in phase space. In [36], the difference between two points $t_{i}$ and $t_{j}$ is denoted by $t_{i}, t_{i+1}, \ldots, t_{i+n}$ and $t_{j}, t_{j+1}, \ldots, t_{j+n}$. The distance $d(k)$ between the two sequences after $k$ steps is calculated using the following formula: $d(k)=\left|t_{i+k}-t_{j+k}\right|$ to measure the convergence and divergence using the Lyapunov Exponent. If the system is chaotic, $d(k)$ will rise exponentially with $k$. Therefore, we can compute and plot $\ln d(k)$ vs $k$ to estimate the Lyapunov Exponent (LE). When the value of LE is very small and close over time, this state indicates that the system is stable and reaches the same solution over time.

In this study, we considered a set of IGD values of 30 independent runs of the DPb-MOPSO algorithm, where $n_{t}$ and $\tau_{t}$ are equal to 10 . The independent IGD values are calculated using the smallest Euclidean distance $d_{i}$ between $i t h$ points in the generated $P O F$ and the true $P O F^{*}$ over time $t$. The stability analysis through Lyapunov Exponent is computed using $\ln (I G D())$. Figure 7 shows the spectrum of the Lyapunov Exponents of F, UDF, FDA, and dMOP functions. Moreover, we can conclude that the Lyapunov exponents for all tested problems are under zero with negative values assuming that the system converges over time. The spectrum of the Lyapunov exponent indicates the stability of DPb-MOPSO with negative values of LE. All location points determine the fast convergence of DPb-MOPSO to all tested problems.
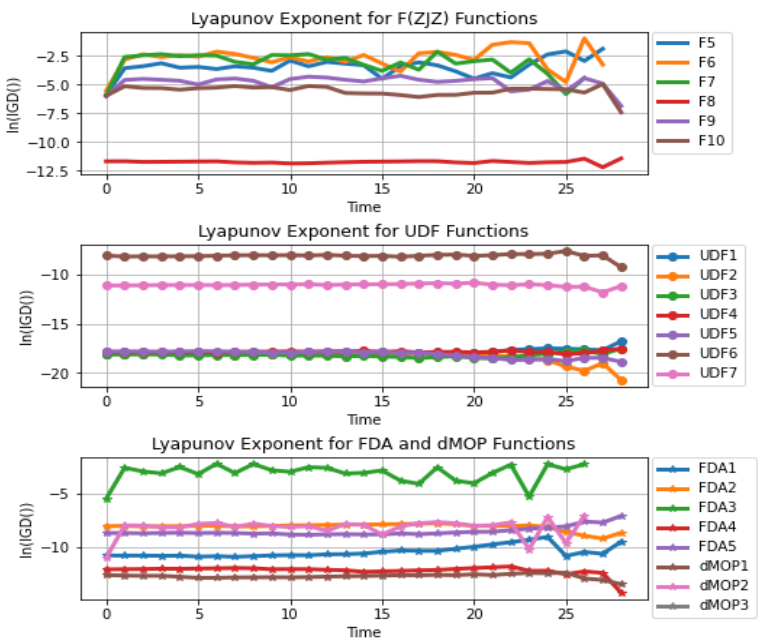

Fig. 7. Spectrum Lyapunov Exponent of DPb-MOPSO for F(ZJZ), UDF, FDA and dMOP Problems.

\section{CONCLUSION}

This study presents a novel Dynamic Pareto bi-level MultiObjective Particle Swarm Optimization (DPb-MOPSO) 
algorithm for solving different types of DMOPs (I, II and III). The proposed DPb-MOPSO has a distributed architecture with two optimization levels, including dynamic handling strategy that effectively detects and responds to changes. In contrast to several MOEAs, Friedman's two-way ANOVA test is used to evaluate the proposed DPb-MOPSO. Based on statistical analysis (at 0.05 significance level), DPb-MOPSO proved to be a more robust algorithm because it can ensure a good trade-off between convergence and diversity in a time-dependent environment. Further, the spectrum of Lyapunov exponents has shown to be an efficient tool for analyzing periodic motions and stability analysis in dynamical systems. The superiority of the proposed method is observed when handling DMOPs with two or three objectives including different types of changes in POS and POF. In conclusion, this study proves the novelty and robustness of DPb-MOPSO in solving dynamic multi-objective problems. However, these characteristics have yet to be explored for problems with more than three objectives. For future work, we will further enhance the proposed approach for DMOPs with dynamic spread and time-varying density of the solutions as well as for pertinent feature selection in real-world problem.

\section{APPENDICES}

See Tables VII, VIII, IX and X below.

\section{ACKNOWLEDGMENT}

We deeply acknowledge Taif University for Supporting this study through Taif University Researchers Supporting Project number (TURSP-2020/327), Taif University, Taif, Saudi Arabia.

The research leading to these results has received funding from the Ministry of Higher Education and Scientific Research of Tunisia under the grant agreement number LR11ES48.

\section{REFERENCES}

[1] M. Farina, K. Deb, and P. Amato, "Dynamic multiobjective optimization problems: Test cases, approximations, and applications," IEEE Transactions on Evolutionary Computation, vol. 8, no. 5, pp. 425-442, Oct. 2004, doi: 10.1109/TEVC.2004.831456

[2] K. Deb, A. Pratap, S. Agarwal, and T. Meyarivan, "A fast and elitist multiobjective genetic algorithm: NSGA-II," IEEE Transactions on Evolutionary Computation, vol. 6, no. 2, pp. 182-197, Apr. 2002, doi: 10.1109/4235.996017.

[3] J. Kennedy and R. Eberhart, "Particle swarm optimization," in Proceedings of ICNN'95 - International Conference on Neural Networks, Nov. 1995, vol. 4, pp. 1942-1948 vol.4. doi: 10.1109/ICNN.1995.488968.

[4] A. Song, W. N. Chen, T. Gu, H. Yuan, S. Kwong, and J. Zhang, "Distributed Virtual Network Embedding System with Historical Archives and Set-Based Particle Swarm Optimization," IEEE Transactions on Systems, Man, and Cybernetics: Systems, vol. 51, no. 2, pp. 927-942, Feb. 2021, doi: 10.1109/TSMC.2018.2884523

[5] Y. Wang and L. Li, "Heterogeneous redundancy allocation for series-parallel multi-state systems using hybrid particle swarm optimization and local search," IEEE Transactions on Systems, Man, and Cybernetics Part A:Systems and Humans, vol. 42, no. 2, pp. 464-474, Mar. 2012, doi: 10.1109/TSMCA.2011.2159585.

[6] H. Chen, M. Li, and X. Chen, "Using diversity as an additional-objective in dynamic multi-objective optimization algorithms," 2nd International Symposium on Electronic Commerce and Security, ISECS 2009, vol. 1, pp. 484-487, 2009, doi: 10.1109/ISECS.2009.42.

[7] Z. Zhang, "Multiobjective optimization immune algorithm in dynamic environments and its application to greenhouse control," Applied Soft Computing, vol. 8, no. 2, pp. 959-971, Mar. 2008, doi: 10.1016/J.ASOC.2007.07.005.

[8] C. A. Liu and Y. Wang, "Dynamic multi-objective optimization evolutionary algorithm," Proceedings - Third International Conference on Natural
Computation, ICNC 2007, vol. 4, pp. 456-459, 2007, doi: 10.1109/ICNC.2007.340.

[9] A. Aboud, R. Fdhila, and A. M. Alimi, "Dynamic Multi Objective Particle Swarm Optimization Based on a New Environment Change Detection Strategy," in Lecture Notes in Computer Science (including subseries Lecture Notes in Artificial Intelligence and Lecture Notes in Bioinformatics), Nov. 2017, vol. 10637 LNCS, pp. 258-268. doi: 10.1007/978-3-319-70093-9_27.

[10] A. Aboud, R. Fdhila, and A. M. Alimi, "MOPSO for dynamic feature selection problem based big data fusion," in 2016 IEEE International Conference on Systems, Man, and Cybernetics, SMC 2016 - Conference Proceedings, Feb. 2017, pp. 3918-3923. doi: 10.1109/SMC.2016.7844846.

[11] R. Azzouz, S. Bechikh, and L. ben Said, "Dynamic Multi-objective Optimization Using Evolutionary Algorithms: A Survey," Adaptation, Learning, and Optimization, vol. 20, pp. 31-70, 2017, doi: 10.1007/978-3319-42978-6_2.

[12] R. Fdhila, C. Walha, T. M. Hamdani, and A. M. Alimi, "Hierarchical design for distributed MOPSO using sub-swarms based on a population Pareto fronts analysis for the grasp planning problem," 13th International Conference on Hybrid Intelligent Systems, HIS 2013, pp. 203-208, Oct. 2014, doi: 10.1109/HIS.2013.6920483.

[13] M. Jiang, Z. Wang, L. Qiu, S. Guo, X. Gao, and K. C. Tan, "A Fast Dynamic Evolutionary Multiobjective Algorithm via Manifold Transfer Learning," IEEE Transactions on Cybernetics, vol. 51, no. 7, pp. 3417-3428, May 2020, doi: 10.1109/TCYB.2020.2989465.

[14] C. A. Coello Coello and M. S. Lechuga, "MOPSO: A proposal for multiple objective particle swarm optimization," Proceedings of the 2002 Congress on Evolutionary Computation, CEC 2002, vol. 2, pp. 1051-1056, 2002, doi: 10.1109/CEC.2002.1004388.

[15] Q. Zhang and H. Li, "MOEA/D: A multiobjective evolutionary algorithm based on decomposition," IEEE Transactions on Evolutionary Computation, vol. 11, no. 6, pp. 712-731, Dec. 2007, doi: 10.1109/TEVC.2007.892759.

[16] C. K. Goh and K. C. Tan, "A competitive-cooperative coevolutionary paradigm for dynamic multiobjective optimization," IEEE Transactions on Evolutionary Computation, vol. 13, no. 1, pp. 103-127, 2009, doi: 10.1109/TEVC.2008.920671

[17] A. Zhou, Y. Jin, and Q. Zhang, "A Population prediction strategy for evolutionary dynamic multiobjective optimization," IEEE Transactions on Cybernetics, vol. 44, no. 1, pp. 40-53, Jan. 2014, doi: 10.1109/TCYB.2013.2245892.

[18] K. Deb, U. B. Rao N., and S. Karthik, "Dynamic multi-objective optimization and decision-making using modified NSGA-II: A case study on hydrothermal power scheduling," in Lecture Notes in Computer Science (including subseries Lecture Notes in Artificial Intelligence and Lecture Notes in Bioinformatics), 2007, vol. 4403 LNCS, pp. 803-817. doi: 10.1007/978-3540-70928-2_60.

[19] S. Jiang and S. Yang, "A Steady-State and Generational Evolutionary Algorithm for Dynamic Multiobjective Optimization," IEEE Transactions on Evolutionary Computation, vol. 21, no. 1, pp. 65-82, Feb. 2017, doi: 10.1109/TEVC.2016.2574621

[20] K. B. Lee and J. H. Kim, "DMOPSO: Dual multi-objective particle swarm optimization," Proceedings of the 2014 IEEE Congress on Evolutionary Computation, CEC 2014, pp. 3096-3102, Sep. 2014, doi: 10.1109/CEC.2014.6900464.

[21] A. Muruganantham, K. C. Tan, and P. Vadakkepat, "Evolutionary Dynamic Multiobjective Optimization Via Kalman Filter Prediction," IEEE Transactions on Cybernetics, vol. 46, no. 12, pp. 2862-2873, Dec. 2016, doi: 10.1109/TCYB.2015.2490738.

[22] L. Cao, L. Xu, E. D. Goodman, C. Bao, and S. Zhu, "Evolutionary Dynamic Multiobjective Optimization Assisted by a Support Vector Regression Predictor," IEEE Transactions on Evolutionary Computation, vol. 24, no. 2, pp. 305-319, Apr. 2020, doi: 10.1109/TEVC.2019.2925722.

[23] M. Jiang, Z. Huang, L. Qiu, W. Huang, and G. G. Yen, "Transfer LearningBased Dynamic Multiobjective Optimization Algorithms," IEEE Transactions on Evolutionary Computation, vol. 22, no. 4, pp. 501-514, Aug. 2018, doi: 10.1109/TEVC.2017.2771451.

[24] S. Biswas, S. Das, P. N. Suganthan, and C. A. C. Coello, "Evolutionary multiobjective optimization in dynamic environments: A set of novel benchmark functions," in Proceedings of the 2014 IEEE Congress on Evolutionary Computation, CEC 2014, Sep. 2014, pp. 3192-3199. doi: 10.1109/CEC.2014.6900487.

[25] S. Nguyen, M. Zhang, M. Johnston, and K. C. Tan, "Automatic design of scheduling policies for dynamic multi-objective job shop scheduling via cooperative coevolution genetic programming," IEEE Transactions on Evolutionary Computation, vol. 18, no. 2, pp. 193-208, 2014, doi: 10.1109/TEVC.2013.2248159.

[26] M. Kim, T. Hiroyasu, M. Miki, and S. Watanabe, "SPEA2+: Improving the Performance of the Strength Pareto Evolutionary Algorithm 2," Lecture Notes in Computer Science (including subseries Lecture Notes in Artificial Intelligence and Lecture Notes in Bioinformatics), vol. 3242, pp. 742-751, 2004, doi: 10.1007/978-3-540-30217-9_75. 
[27] S. Seifollahi-Aghmiuni and O. Bozorg Haddad, "Multi Objective Optimization with a New Evolutionary Algorithm," Water Resources Management 2018 32:12, vol. 32, no. 12, pp. 4013-4030, Jul. 2018, doi: 10.1007/S11269-018-2034-1.

[28] R. Azzouz, S. Bechikh, and L. ben Said, "A dynamic multi-objective evolutionary algorithm using a change severity-based adaptive population management strategy," Soft Computing 2015 21:4, vol. 21, no. 4, pp. 885906, Aug. 2015, doi: 10.1007/S00500-015-1820-4.

[29] M. Cámara, J. Ortega, and F. J. Toro, "Parallel processing for multi-objective optimization in dynamic environments," Proceedings - 21st International Parallel and Distributed Processing Symposium, IPDPS 2007; Abstracts and CD-ROM, 2007, doi: 10.1109/IPDPS.2007.370433.

[30] S. Jiang, S. Yang, X. Yao, K. Tan, M. Kaiser, and N. Krasnogor, "Benchmark Problems for CEC2018 Competition on Dynamic Multiobjective Optimisation," 2018.

[31] R. Azzouz, S. Bechikh, and L. ben Said, "Multi-objective optimization with dynamic constraints and objectives: New challenges for evolutionary algorithms," GECCO 2015 - Proceedings of the 2015 Genetic and Evolutionary Computation Conference, pp. 615-622, Jul. 2015, doi: 10.1145/2739480.2754708.

[32] E. J. Hughes, "MSOPS-II: A general-purpose many-objective optimiser," in 2007 IEEE Congress on Evolutionary Computation, CEC 2007, 2007, pp. 3944-3951. doi: 10.1109/CEC.2007.4424985.

[33] J. J. Durillo and A. J. Nebro, "JMetal: A Java framework for multi-objective optimization," Advances in Engineering Software, vol. 42, no. 10, pp. 760771, Oct. 2011, doi: 10.1016/j.advengsoft.2011.05.014.

[34] J. Derrac, S. García, D. Molina, and F. Herrera, "A practical tutorial on the use of nonparametric statistical tests as a methodology for comparing evolutionary and swarm intelligence algorithms," Swarm and Evolutionary Computation, vol. 1, no. 1, pp. 3-18, Mar. 2011, doi: 10.1016/J.SWEVO.2011.02.002.

[35] A. M. LYAPUNOV, "The general problem of the stability of motion," http://dx.doi.org/10.1080/00207179208934253, vol. 55, no. 3, pp. 531-534, 2007, doi: $10.1080 / 00207179208934253$.

[36] B. B and D. C, "Stochastic neural network model for spontaneous bursting in hippocampal slices," Physical review. E, Statistical, nonlinear, and soft matter physics, vol. 66, no. 5 Pt 1, p. 18, Nov. 2002, doi: 10.1103/PHYSREVE.66.051908.

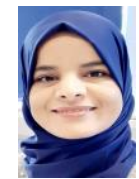

Ahlem Aboud she is currently a $\mathrm{PhD}$ student in computer science in ISITCom, University of Sousse and with the REsearch Group on Intelligent Machines (REGIM-lab) at ENIS Sfax, University of Sfax. She received his engineering degree in 2015 from the ISIMS Sfax. She is currently IEEE student member since October 2015. His research interests include, dynamic multi-objective optimization problem, evolutionary computation and collective intelligence methods.

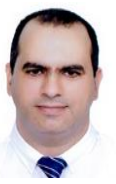

Nizar Rokbani (IEEE SM), He is an Assit Prof of Industrial Computing with Institute of Applied Science and technology of Sousse, Tunisia where he is a lecturer since 2014. He graduated in Electrical Engineering from the National Engineering School of Tunis, ENIT in 1995. He obtained a Master degree in industrial computing in 2003 from the National Engineering School of Sfax, ENIS, and a PHD in Electrical Engineering in 2013. He was an automation process engineer until 1998, he was then a technologic trainer at the institute of technological studies of Gabes, occupied a post of training adviser engineer at the national agency of vocational training from 2003 to 2006. His research interests include applications of intelligent techniques such as Swarm intelligence, computational intelligence, fuzzy logic, evolutionary algorithms to robotic systems and industrial processes. Dr. Nizar Rokbani is an IEEE member \& volunteer, He participated in funding several society chapters, including RAS and SMC 2009, and OES 2016, he is also the founding counselor of ISSAT Sousse Sb 2015, and Polytech Sousse Sb, 2016. He is The IEEE RAS Tunisia Chair 2015-20120, the chapter was awarded: R8 Outstanding Society Chapter 2016, Best RAS Society Chapter award for 2017, and Outstanding Society chapter award of Tunisia Section for 2017. In 2019, He received the the Meritorious Achievement Award in Pre-University Education of the IEEE Educational Activities Board (EAB) for his efforst in promoting STEM \& Robotics education in tunisia primary schools.

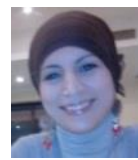

Raja Fdhila she holds an engineering degree in computer science and a Master's degree in automation and signal processing from the National School of Engineers of Tunis in 2005 and 2007 respectively. She obtained her doctorate in computer systems engineering from ENIS Sfax in 2017. She is member of the REGIM-lab at ENIS Sfax. She works mainly in the field of artificial intelligence, and is particularly interested in multi-objective optimization, collective intelligence, multi-agent systems. She has been an IEEE member since 2008.

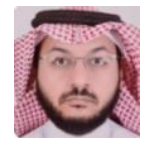

Dr Abdulrahman Qahtani is currently Assistant professor in computer science department at Taif University. Dr. Qahtani received his PhD from Southampton University in 2015. He has extensive experience in software engineering and development process in a distributed domain. His research focused on customization process across organizational boundaries. Recently, he applied machine learning algorithms on software engineering data to predict time and cost estimation for multi-clients projects.

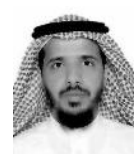

Omar Almutiry received the $\mathrm{PhD}$ degree from the University of Southampton, UK, in 2017. Since 2018, he has been with the Applied Computer Science College, King Saud University, Saudi Arabia, where he is currently working as an Assistant Professor with the Department of Applied Computer Sciences. He is also assistant to the General Director of the Almuzahmiyah branch for academic affairs and development. His research areas include data science, health informatics, deep learning applications in healthcare and medical fields.

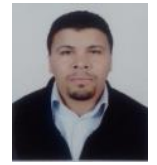

Habib Dhahri was born in Sidi Bouzid, Tunisia in 1975. He graduated in Computer Science in 2001, obtained his $\mathrm{PhD}$ in Computer Science in 2013 from the National Engineering School of Sfax (ENIS). He is now an assistant professor in Computer Science at the King Saud University. His area of interest includes computational intelligence, soft computing techniques and Machine Learning for Healthcare Data. He has authored and coauthored more than 30 publications in journals and conferences. He also serves as a reviewer for several international scientific journals.

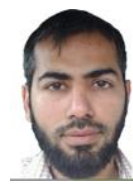

Amir Hussain he received his B.Eng (highest $1^{\text {st }}$ Class Honours with distinction) and $\mathrm{Ph} . \mathrm{D}$ degrees, from the University of Strathclyde, Glasgow, U.K., in 1992 and 1997, respectively. Following postdoctoral and academic positions at the Universities of West of Scotland (1996-98), Dundee (19982000) and Stirling (2000-18) respectively, he joined Edinburgh Napier University (in Scotland, UK) in 2018 as Professor and founding Head of the Data Science and Cyber Analytics (DSCA) Research Group (managing 20 academics and research staff). As part of the latter, he is also founding Head of the Cognitive Big Data and Cybersecurity (CogBiD) Research Lab

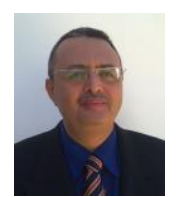

Adel M. Alimi (S'91-M'96-SM'00) was born in Sfax, Tunisia, in 1966. He received the Degree in electrical engineering in 1990, the Ph.D. degree in electrical and computer engineering from the Polytechnic University of Montreal, Montr' eal, QC, ' Canada, in 1995, and the HDR degree in electrical and computer engineering from the National Engineering School of Sfax, Sfax, in 2000. He is currently a Professor of electrical and computer engineering with the University of Sfax, Sfax. His current research interests include applications of intelligent methods (neural networks, fuzzy logic, and evolutionary algorithms) to pattern recognition, robotic systems, vision systems, industrial processes, intelligent pattern recognition, learning, analysis, and intelligent control of large-scale complex systems. Prof. Alimi is a member of IAPR, INNS, and PRS. He is a member and an Associate Editor of the Editorial Board of many international scientific journals, including Pattern Recognition Letters, Neurocomputing, Neural Processing Letters, International Journal of Image and Graphics, Neural Computing and Applications, International Journal of Robotics and Automation, and International Journal of Systems Science. He was a Guest Editor of several special issues of international journals, including Fuzzy Sets and Systems, Soft Computing, the Journal of Decision Systems, Integrated Computer-Aided Engineering, and Systems Analysis Modeling and Simulations. 
TABLE VII. Mean and Standard Deviation Values of all MOEAs over IGD and HVD for UDF, F Functions with Moderate Environmental Changes $\left(\tau_{t}=n_{t}=10\right)$.

\begin{tabular}{|c|c|c|c|c|c|c|c|c|c|c|c|c|}
\hline \multirow{2}{*}{ Prob. } & \multirow[b]{2}{*}{ QI } & \multirow[b]{2}{*}{ Val. } & \multicolumn{5}{|c|}{ tested Algorithms of Jiang et al. [15] } & \multicolumn{5}{|c|}{ Additional Tested MOPSO based Algorithms } \\
\hline & & & DNSGA-II & dCOEA & PPS & MOEA/D & SGEA & MOPSO & dMOPSO & pbMOPSO & Dynamic-MOPSO & DPb-MOPSO \\
\hline \multirow[b]{3}{*}{ UDF1 } & HVD & M. & $5.14 \mathrm{E}-1$ & 7.47E-1 & $\begin{array}{l}7.97 \mathrm{E}-1 \\
5\end{array}$ & $6.12 \mathrm{E}-1$ & $5.18 \mathrm{E}-1$ & $\begin{array}{l}2.99 \mathrm{E}+0 \\
1 . \mathrm{E}_{-}-5\end{array}$ & $\begin{array}{l}2.99 \mathrm{E}+0 \\
11 \mathrm{~F}-7\end{array}$ & $5.78 \mathrm{E}-3$ & $\begin{array}{l}.01 \mathrm{E}-3 \\
18 \mathrm{E}-5\end{array}$ & $4.65 \mathrm{E}-3$ \\
\hline & \multirow[b]{2}{*}{ IGD } & $\frac{\text { Std. }}{\text { M. }}$ & $\begin{array}{r}3.2 \mathrm{E}-2 \\
1.07 \mathrm{E}-1\end{array}$ & $\frac{3.8 \mathrm{E}-2}{2.91 \mathrm{E}-1}$ & $\frac{5.2 \mathrm{E}-2}{2.67 \mathrm{E}-1}$ & $\begin{array}{r}9.4 \mathrm{E}-2 \\
1.70 \mathrm{E}-1\end{array}$ & $\begin{array}{r}5.0 \mathrm{E}-2 \\
1.24 \mathrm{E}-1\end{array}$ & $\begin{array}{r}1.2 \mathrm{E}-5 \\
5.52 \mathrm{E}-3\end{array}$ & $\begin{array}{r}1.1 \mathrm{E}-7 \\
5.52 \mathrm{E}-3\end{array}$ & $\frac{3.0 \mathrm{E}-4}{9.26 \mathrm{E}-5}$ & $\begin{array}{r}1.8 \mathrm{E}-5 \\
4.97 \mathrm{E}-5\end{array}$ & $\begin{array}{r}1.7 \mathrm{E}-4 \\
4.64 \mathrm{E}-5\end{array}$ \\
\hline & & Std. & $2.4 \mathrm{E}-2$ & $2.3 \mathrm{E}-2$ & $2.2 \mathrm{E}-2$ & $5.1 \mathrm{E}-2$ & $3.3 \mathrm{E}-2$ & $8.2 \mathrm{E}-11$ & $1.0 \mathrm{E}-10$ & $5.3 \mathrm{E}-6$ & 4.1E-7 & 3.1E-6 \\
\hline \multirow{4}{*}{ UDF2 } & \multirow[b]{2}{*}{ HVD } & M. & $5.51 \mathrm{E}-1$ & $6.13 \mathrm{E}-1$ & $4.32 \mathrm{E}-1$ & $5.42 \mathrm{E}-1$ & $5.10 \mathrm{E}-1$ & $2.99 \mathrm{E}+0$ & $2.99 \mathrm{E}+0$ & $5.80 \mathrm{E}-3$ & $5.01 \mathrm{E}-3$ & $4.66 \mathrm{E}-3$ \\
\hline & & Std. & $2.4 \mathrm{E}-2$ & $2.8 \mathrm{E}-2$ & $1.9 \mathrm{E}-2$ & $1.7 \mathrm{E}-2$ & $2.5 \mathrm{E}-2$ & $9.5 \mathrm{E}-6$ & $1.1 \mathrm{E}-7$ & 3.3E-4 & $1.9 \mathrm{E}-5$ & 2.7E-4 \\
\hline & \multirow[b]{2}{*}{ IGD } & M. & $1.12 \mathrm{E}-1$ & $1.83 \mathrm{E}-1$ & $2.54 \mathrm{E}-2$ & $1.16 \mathrm{E}-1$ & $8.95 \mathrm{E}-2$ & $5.53 \mathrm{E}-3$ & $5.53 \mathrm{E}-3$ & $9.36 \mathrm{E}-5$ & $4.94 \mathrm{E}-5$ & $4.67 \mathrm{E}-5$ \\
\hline & & Std. & $1.0 \mathrm{E}-2$ & $2.0 \mathrm{E}-2$ & $5.0 \mathrm{E}-3$ & $9.5 \mathrm{E}-3$ & $1.3 \mathrm{E}-2$ & $1.6 \mathrm{E}-10$ & $0.0 \mathrm{E}+0$ & $5.9 \mathrm{E}-6$ & $4.6 \mathrm{E}-7$ & $3.0 \mathrm{E}-6$ \\
\hline \multirow{4}{*}{ UDF3 } & \multirow[b]{2}{*}{ HVD } & M. & $1.22 \mathrm{E}+0$ & $1.23 \mathrm{E}+0$ & $1.73 \mathrm{E}+0$ & $1.22 \mathrm{E}+0$ & $1.22 \mathrm{E}+0$ & $5.05 \mathrm{E}-3$ & $5.04 \mathrm{E}-3$ & $4.50 \mathrm{E}-3$ & $4.92 \mathrm{E}-3$ & $4.63 \mathrm{E}-3$ \\
\hline & & Std. & $1.9 \mathrm{E}-3$ & $7.0 \mathrm{E}-2$ & $3.1 \mathrm{E}-4$ & $2.4 \mathrm{E}-3$ & $2.4 \mathrm{E}-3$ & $1.4 \mathrm{E}-5$ & $1.1 \mathrm{E}-7$ & $2.4 \mathrm{E}-4$ & 7.1E-6 & $2.4 \mathrm{E}-4$ \\
\hline & \multirow{2}{*}{ IGD } & M. & $6.06 \mathrm{E}-1$ & $6.51 \mathrm{E}-1$ & $4.55 \mathrm{E}+0$ & $6.06 \mathrm{E}-1$ & $6.06 \mathrm{E}-1$ & $1.52 \mathrm{E}-5$ & $1.48 \mathrm{E}-5$ & $6.17 \mathrm{E}-5$ & $4.55 \mathrm{E}-5$ & $4.73 \mathrm{E}-5$ \\
\hline & & Std. & $3.3 \mathrm{E}-6$ & 7.7E-2 & $1.1 \mathrm{E}+0$ & $6.3 \mathrm{E}-5$ & 7.4E-6 & $8.1 \mathrm{E}-8$ & $5.6 \mathrm{E}-10$ & $3.8 \mathrm{E}-6$ & $3.7 \mathrm{E}-7$ & $2.9 \mathrm{E}-6$ \\
\hline \multirow{4}{*}{ UDF4 } & \multirow[b]{2}{*}{ HVD } & M. & $3.47 \mathrm{E}-1$ & $5.06 \mathrm{E}-1$ & $3.77 \mathrm{E}-1$ & $6.41 \mathrm{E}-1$ & $3.32 \mathrm{E}-1$ & $2.44 \mathrm{E}-2$ & $2.39 \mathrm{E}-2$ & $2.33 \mathrm{E}-3$ & $6.78 \mathrm{E}-3$ & $6.97 \mathrm{E}-4$ \\
\hline & & Std. & 8.3E-2 & $3.7 \mathrm{E}-2$ & $2.1 \mathrm{E}-2$ & $1.9 \mathrm{E}-1$ & 7.1E-2 & $1.8 \mathrm{E}-5$ & $1.6 \mathrm{E}-7$ & $3.2 \mathrm{E}-4$ & $1.1 \mathrm{E}-4$ & $2.8 \mathrm{E}-4$ \\
\hline & & M. & $1.70 \mathrm{E}-1$ & $2.87 \mathrm{E}-1$ & $1.85 \mathrm{E}-1$ & $3.19 \mathrm{E}-1$ & $1.68 \mathrm{E}-1$ & $8.18 \mathrm{E}-5$ & $8.18 \mathrm{E}-5$ & $6.36 \mathrm{E}-5$ & $5.21 \mathrm{E}-5$ & 4.81E-5 \\
\hline & IGD & Std. & $4.7 \mathrm{E}-2$ & $2.8 \mathrm{E}-2$ & $8.2 \mathrm{E}-3$ & $1.3 \mathrm{E}-1$ & 4.4E- 2 & $2.1 \mathrm{E}-8$ & $1.8 \mathrm{E}-10$ & $3.2 \mathrm{E}-6$ & $1.0 \mathrm{E}-6$ & $1.8 \mathrm{E}-6$ \\
\hline & & M. & $2.78 \mathrm{E}-1$ & $3.98 \mathrm{E}-1$ & $2.70 \mathrm{E}-1$ & $3.65 \mathrm{E}-1$ & $2.72 \mathrm{E}-1$ & $2.44 \mathrm{E}-2$ & $2.39 \mathrm{E}-2$ & $2.24 \mathrm{E}-3$ & $6.74 \mathrm{E}-3$ & $6.49 \mathrm{E}-4$ \\
\hline & HVD & Std. & $2.5 \mathrm{E}-2$ & 3.3E- 2 & $1.5 \mathrm{E}-2$ & $2.7 \mathrm{E}-2$ & $1.8 \mathrm{E}-2$ & $1.7 \mathrm{E}-5$ & $1.5 \mathrm{E}-7$ & $2.7 \mathrm{E} 4$ & $1.4 \mathrm{E}-4$ & $2.8 \mathrm{E}-4$ \\
\hline & & M. & $1.18 \mathrm{E}-1$ & $2.05 \mathrm{E}-1$ & $2.89 \mathrm{E}-2$ & $1.61 \mathrm{E}-1$ & $1.00 \mathrm{E}-1$ & $8.21 \mathrm{E}-5$ & $8.21 \mathrm{E}-5$ & $6.38 \mathrm{E}-5$ & $5.14 \mathrm{E}-5$ & $4.68 \mathrm{E}-5$ \\
\hline UDF5 & IGD & Std. & $1.2 \mathrm{E}-2$ & $3.5 \mathrm{E}-2$ & $1.3 \mathrm{E}-2$ & $1.4 \mathrm{E}-2$ & $1.1 \mathrm{E}-2$ & $1.6 \mathrm{E}-8$ & $2.0 \mathrm{E}-10$ & $3.1 \mathrm{E}-6$ & $1.3 \mathrm{E}-6$ & 2.2E-6 \\
\hline & & M. & $9.34 \mathrm{E}-1$ & $1.26 \mathrm{E}+0$ & $1.83 \mathrm{E}+0$ & $1.21 \mathrm{E}+0$ & $9.77 \mathrm{E}-1$ & $3.96 \mathrm{E}+2$ & $3.99 \mathrm{E}+2$ & $1.50 \mathrm{E}-2$ & $1.83 \mathrm{E}-2$ & $5.86 \mathrm{E}-3$ \\
\hline & HVD & Std. & $1.5 \mathrm{E}-1$ & 7.2E-2 & $1.0 \mathrm{E}-2$ & $1.4 \mathrm{E}-1$ & $2.0 \mathrm{E}-1$ & 6.7E-3 & $3.6 \mathrm{E}-2$ & $1.8 \mathrm{E}-2$ & $9.7 \mathrm{E}-3$ & $1.6 \mathrm{E}-3$ \\
\hline & & M. & 4.57E-1 & $8.04 \mathrm{E}-1$ & $1.34 \mathrm{E}+0$ & $5.31 \mathrm{E}-1$ & $6.68 \mathrm{E}-1$ & $2.88 \mathrm{E}+0$ & $2.88 \mathrm{E}+0$ & $8.63 \mathrm{E}-4$ & $1.93 \mathrm{E}-3$ & 4.05E-4 \\
\hline UDF6 & IGD & Std. & $8.7 \mathrm{E}-2$ & $1.0 \mathrm{E}-1$ & 7.1E-2 & $1.6 \mathrm{E}-1$ & $2.0 \mathrm{E}-1$ & $2.3 \mathrm{E}-6$ & $1.8 \mathrm{E}-6$ & $4.5 \mathrm{E}-4$ & $2.5 \mathrm{E}-4$ & $1.2 \mathrm{E}-4$ \\
\hline & & M. & $2.40 \mathrm{E}+0$ & $1.91 \mathrm{E}+0$ & $2.06 \mathrm{E}+0$ & $2.32 \mathrm{E}+0$ & $2.06 \mathrm{E}+0$ & $4.62 \mathrm{E}+0$ & $1.57 \mathrm{E}+1$ & $1.93 \mathrm{E}+0$ & $1.43 \mathrm{E}-1$ & $1.93 \mathrm{E}+0$ \\
\hline & HVD & Std. & 7.4E-2 & $1.7 \mathrm{E}-1$ & $5.4 \mathrm{E}-2$ & $2.4 \mathrm{E}-1$ & $1.2 \mathrm{E}-1$ & $3.0 \mathrm{E}-2$ & $5.6 \mathrm{E}-1$ & $1.2 \mathrm{E}-1$ & $1.2 \mathrm{E}-1$ & $1.2 \mathrm{E}+0$ \\
\hline 5 FE7 & & M. & $5.24 \mathrm{E}-1$ & $8.40 \mathrm{E}-1$ & $6.68 \mathrm{E}-1$ & $5.08 \mathrm{E}-1$ & $5.08 \mathrm{E}-1$ & $3.73 \mathrm{E}-1$ & $3.81 \mathrm{E}-1$ & $1.27 \mathrm{E}-4$ & $1.93 \mathrm{E}-3$ & $7.58 \mathrm{E}-4$ \\
\hline UDF? & IGD & Std. & $2.2 \mathrm{E}-2$ & $6.4 \mathrm{E}-2$ & $4.4 \mathrm{E}-2$ & $1.4 \mathrm{E}-1$ & 4.2E- 2 & $2.3 \mathrm{E}-6$ & 7.7E-3 & $1.6 \mathrm{E}-5$ & $3.0 \mathrm{E}-4$ & $4.8 \mathrm{E}-5$ \\
\hline & HVD & M. & $1.25 \mathrm{E}+0$ & $1.10 \mathrm{E}+0$ & $4.01 \mathrm{E}-1$ & $1.19 \mathrm{E}+0$ & $7.16 \mathrm{E}-1$ & $4.73 \mathrm{E}+3$ & $5.23 \mathrm{E}+3$ & $1.31 \mathrm{E}+0$ & $4.86 \mathrm{E}-2$ & $2.99 \mathrm{E}-1$ \\
\hline & HVD & Std. & $2.5 \mathrm{E}-2$ & $1.6 \mathrm{E}-1$ & $9.9 \mathrm{E}-2$ & $2.9 \mathrm{E}-2$ & $8.2 \mathrm{E}-2$ & $9.7 \mathrm{E}+29$ & $9.7 \mathrm{E}+2$ & $1.2 \mathrm{E}+0$ & $6.4 \mathrm{E}-2$ & $2.4 \mathrm{E}-1$ \\
\hline F5 & & M. & $7.82 \mathrm{E}-1$ & $8.01 \mathrm{E}-1$ & $2.69 \mathrm{E}-1$ & $6.88 \mathrm{E}-1$ & $4.41 \mathrm{E}-1$ & $4.80 \mathrm{E}+0$ & $6.62 \mathrm{E}+0$ & $9.71 \mathrm{E}-3$ & $2.75 \mathrm{E}-3$ & $2.72 \mathrm{E}-3$ \\
\hline F5 & IGD & Std. & 3.9E-2 & $2.2 \mathrm{E}-1$ & 4.3E-2 & $4.1 \mathrm{E}-2$ & $4.5 \mathrm{E}-2$ & $8.2 \mathrm{E}-2$ & $0.0 \mathrm{E}+0$ & $5.8 \mathrm{E}-3$ & $8.9 \mathrm{E}-4$ & $6.5 \mathrm{E}-4$ \\
\hline & HVD & M. & $4.76 \mathrm{E}-1$ & $9.22 \mathrm{E}-1$ & $4.92 \mathrm{E}-1$ & $5.75 \mathrm{E}-1$ & $3.60 \mathrm{E}-1$ & $9.86 \mathrm{E}+3$ & $1.53 \mathrm{E}+1$ & $1.19 \mathrm{E}+1$ & $8.87 \mathrm{E}-2$ & $5.99 \mathrm{E}-2$ \\
\hline & HVD & Std. & $3.7 \mathrm{E}-2$ & $1.0 \mathrm{E}-1$ & $1.5 \mathrm{E}-1$ & $7.5 \mathrm{E}-2$ & $2.5 \mathrm{E}-2$ & $1.4 \mathrm{E}+30$ & $1.2 \mathrm{E}+2$ & $1.8 \mathrm{E}+1$ & $2.5 \mathrm{E}-1$ & $5.5 \mathrm{E}-2$ \\
\hline F6 & JGD & M. & $3.02 \mathrm{E}-1$ & $6.57 \mathrm{E}-1$ & $2.60 \mathrm{E}-1$ & $3.44 \mathrm{E}-1$ & $2.90 \mathrm{E}-1$ & $6.73 \mathrm{E}-1$ & $6.95 \mathrm{E}-1$ & $\begin{array}{l}5.76 \mathrm{E}-2 \\
\end{array}$ & $1.53 \mathrm{E}-3$ & $1.49 \mathrm{E}-3$ \\
\hline Fo & IGD & Std. & $2.1 \mathrm{E}-2$ & $1.3 \mathrm{E}-1$ & $6.5 \mathrm{E}-2$ & $5.6 \mathrm{E}-2$ & $1.3 \mathrm{E}-2$ & $3.6 \mathrm{E}-3$ & $1.8 \mathrm{E}-3$ & $1.9 \mathrm{E}-2$ & $1.9 \mathrm{E}-3$ & $4.1 \mathrm{E}-4$ \\
\hline & HVD & M. & $6.49 \mathrm{E}-1$ & $1.22 \mathrm{E}+0$ & $4.49 \mathrm{E}-1$ & $6.50 \mathrm{E}-1$ & $6.05 \mathrm{E}-1$ & $7.07 \mathrm{E}+3$ & $1.13 \mathrm{E}+3$ & $1.05 \mathrm{E}+1$ & $3.63 \mathrm{E}-1$ & $5.07 \mathrm{E}+0$ \\
\hline & HVD & Std. & $1.0 \mathrm{E}-2$ & $1.5 \mathrm{E}-1$ & $1.4 \mathrm{E}-1$ & $2.8 \mathrm{E}-2$ & $1.5 \mathrm{E}-2$ & $6.0 \mathrm{E}+3$ & $0.0 \mathrm{E}+0$ & $1.5 \mathrm{E}+1$ & $6.0 \mathrm{E}-1$ & $1.4 \mathrm{E}+1$ \\
\hline F7 & ICD & M. & $4.19 \mathrm{E}-1$ & $1.56 \mathrm{E}+0$ & $2.63 \mathrm{E}-1$ & $4.18 \mathrm{E}-1$ & $4.47 \mathrm{E}-1$ & $4.00 \mathrm{E}-1$ & $4.26 \mathrm{E}-1$ & $2.96 \mathrm{E}-2$ & $6.41 \mathrm{E}-3$ & $9.97 \mathrm{E}-3$ \\
\hline F7 & IGD & Std. & $6.9 \mathrm{E}-3$ & $6.0 \mathrm{E}-1$ & 7.1E-2 & $6.0 \mathrm{E}-2$ & $1.0 \mathrm{E}-2$ & $1.5 \mathrm{E}-4$ & $1.3 \mathrm{E}-8$ & 7.3E-3 & $2.3 \mathrm{E}-3$ & $5.9 \mathrm{E}-3$ \\
\hline & HYD & M. & $1.06 \mathrm{E}+0$ & $8.85 \mathrm{E}-1$ & $1.34 \mathrm{E}+0$ & $1.06 \mathrm{E}+0$ & $4.57 \mathrm{E}-1$ & $1.67 \mathrm{E}+4$ & $1.34 \mathrm{E}+4$ & $5.85 \mathrm{E}-3$ & $3.84 \mathrm{E}-2$ & $4.55 \mathrm{E}-3$ \\
\hline & HVD & Std. & $4.6 \mathrm{E}-2$ & $1.2 \mathrm{E}-1$ & $1.0 \mathrm{E}-1$ & $6.6 \mathrm{E}-2$ & $3.2 \mathrm{E}-2$ & $1.7 \mathrm{E}+4$ & $1.1 \mathrm{E}+4$ & $2.7 \mathrm{E}-3$ & $4.4 \mathrm{E}-3$ & $1.2 \mathrm{E}-3$ \\
\hline F8 & & M. & $4.86 \mathrm{E}-1$ & $4.00 \mathrm{E}-1$ & $4.56 \mathrm{E}-1$ & $5.49 \mathrm{E}-1$ & $2.51 \mathrm{E}-1$ & $1.15 \mathrm{E}-3$ & $6.27 \mathrm{E}-3$ & $3.41 \mathrm{E}-4$ & $6.84 \mathrm{E}-4$ & $1.93 \mathrm{E}-4$ \\
\hline F8 & IGD & Std. & $1.3 \mathrm{E}-2$ & $6.7 \mathrm{E}-2$ & $3.1 \mathrm{E}-2$ & $2.3 \mathrm{E}-2$ & $1.4 \mathrm{E}-1$ & $8.1 \mathrm{E}-5$ & $7.2 \mathrm{E}-4$ & $1.4 \mathrm{E}-5$ & $2.4 \mathrm{E}-5$ & $5.1 \mathrm{E}-6$ \\
\hline & & M. & $8.87 \mathrm{E}-1$ & $1.07 \mathrm{E}+0$ & $6.88 \mathrm{E}-1$ & $8.58 \mathrm{E}-1$ & $5.76 \mathrm{E}-1$ & $4.98 \mathrm{E}+3$ & $2.62 \mathrm{E}+3$ & $1.45 \mathrm{E}+0$ & $8.42 \mathrm{E}-2$ & $2.22 \mathrm{E}-1$ \\
\hline & HVD & Std. & 3.4E- 2 & $1.9 \mathrm{E}-1$ & 7.7E-2 & $4.6 \mathrm{E}-2$ & $7.0 \mathrm{E}-2$ & $8.4 \mathrm{E}+29$ & $9.7 \mathrm{E}-5$ & $1.1 \mathrm{E}+0$ & $1.0 \mathrm{E}-1$ & $3.5 \mathrm{E}-1$ \\
\hline F9 & IGD & M. & $4.74 \mathrm{E}-1$ & $8.87 \mathrm{E}-1$ & $3.59 \mathrm{E}-1$ & $4.29 \mathrm{E}-1$ & $3.65 \mathrm{E}-1$ & $1.46 \mathrm{E}+0$ & $1.99 \mathrm{E}+0$ & $9.65 \mathrm{E}-3$ & $1.86 \mathrm{E}-3$ & $2.99 \mathrm{E}-3$ \\
\hline F9 & IGD & Std. & $2.1 \mathrm{E}-2$ & $3.3 \mathrm{E}-1$ & $4.4 \mathrm{E}-2$ & $2.4 \mathrm{E}-2$ & $3.4 \mathrm{E}-2$ & $1.1 \mathrm{E}-1$ & $0.0 \mathrm{E}+0$ & $3.4 \mathrm{E}-3$ & $7.2 \mathrm{E}-4$ & $1.3 \mathrm{E}-3$ \\
\hline & HVD & M. & $1.22 \mathrm{E}+0$ & $8.58 \mathrm{E}-1$ & $5.38 \mathrm{E}-1$ & $1.05 \mathrm{E}+0$ & $5.77 \mathrm{E}-1$ & $1.23 \mathrm{E}+3$ & $1.98 \mathrm{E}+3$ & $1.33 \mathrm{E}+0$ & $6.69 \mathrm{E}-2$ & $2.85 \mathrm{E}-1$ \\
\hline & HVD & Std. & $5.0 \mathrm{E}-2$ & $8.8 \mathrm{E}-2$ & $1.2 \mathrm{E}-1$ & $5.9 \mathrm{E}-2$ & $2.3 \mathrm{E}-2$ & $1.2 \mathrm{E}+3$ & $0.0 \mathrm{E}+0$ & $1.0 \mathrm{E}+0$ & $6.0 \mathrm{E}-2$ & $2.1 \mathrm{E}-1$ \\
\hline F10 & IGD & M. & $1.05 \mathrm{E}+0$ & $5.76 \mathrm{E}-1$ & $3.79 \mathrm{E}-1$ & $6.39 \mathrm{E}-1$ & $3.80 \mathrm{E}-1$ & $1.29 \mathrm{E}+0$ & $1.76 \mathrm{E}+0$ & $7.53 \mathrm{E}-3$ & $2.35 \mathrm{E}-3$ & $3.02 \mathrm{E}-3$ \\
\hline Fio & IGD & Std. & $1.5 \mathrm{E}-1$ & $8.1 \mathrm{E}-2$ & $8.7 \mathrm{E}-2$ & 8.6E-2 & $1.3 \mathrm{E}-2$ & $1.9 \mathrm{E}-2$ & $5.2 \mathrm{E}-8$ & $3.0 \mathrm{E}-3$ & $5.9 \mathrm{E}-4$ & $8.4 \mathrm{E}-4$ \\
\hline
\end{tabular}


TABLE VIII. Mean and Standard Deviation Values over MIGD for FDA and dMOP Functions with Severe, Moderate and Slight Environmental Changes.

\begin{tabular}{|c|c|c|c|c|c|c|c|c|c|c|c|c|c|}
\hline \multirow[t]{2}{*}{ Prob. } & \multirow[t]{2}{*}{$\left(\tau_{t}, n_{t}\right)$} & \multirow[t]{2}{*}{ Values } & \multicolumn{5}{|c|}{$\begin{array}{c}\text { Transfer Learning-based Methods Tested in [14] } \\
\end{array}$} & \multirow[b]{2}{*}{ RI-MOEA/D } & \multirow{2}{*}{ MOPSO } & \multicolumn{4}{|c|}{ MOPSO-based Methods } \\
\hline & & & MMTL-MOEA/D & KF-MOEA/D & PPS-MOEA/D & SVR-MOEA/D & Tr-MOEA/D & & & dMOPSO & pbMOPSO & $\begin{array}{l}\text { Dynamic- } \\
\text { MOPSO }\end{array}$ & DPb-MOPSO \\
\hline \multirow{3}{*}{ FDA1 } & $(5,10)$ & $\begin{array}{l}\text { M. } \\
\text { Std. }\end{array}$ & $\begin{array}{c}0.1214 \\
1.07 \mathrm{E}-1\end{array}$ & $\begin{array}{c}0.4670 \\
3.38 \mathrm{E}-1\end{array}$ & $\begin{array}{c}0.2485 \\
1.40 \mathrm{E}-1\end{array}$ & $\begin{array}{c}0.3745 \\
3.12 \mathrm{E}-1\end{array}$ & $\begin{array}{c}0.3381 \\
2.14 \mathrm{E}-1\end{array}$ & $\begin{array}{c}0.3166 \\
3.58 \mathrm{E}-1\end{array}$ & \begin{tabular}{|l|}
$1.97 \mathrm{E}-4$ \\
$3.6 \mathrm{E}-6$
\end{tabular} & $\begin{array}{c}5.85 \mathrm{E}-04 \\
2.2 \mathrm{E}-5\end{array}$ & $\begin{array}{l}1.13 \mathrm{E}-2 \\
4.6 \mathrm{E}-3\end{array}$ & $\begin{array}{l}8.77 \mathrm{E}-3 \\
3.6 \mathrm{E}-3\end{array}$ & $\begin{array}{l}1.68 \mathrm{E}-2 \\
8.1 \mathrm{E}-3\end{array}$ \\
\hline & $(10,10)$ & $\begin{array}{c}\text { M. } \\
\text { Std. }\end{array}$ & $\begin{array}{c}0.1199 \\
7.93 \mathrm{E}-2 \\
\end{array}$ & $\begin{array}{c}0.2659 \\
1.23 \mathrm{E}-1 \\
\end{array}$ & $\begin{array}{c}0.2141 \\
1.22 \mathrm{E}-1 \\
\end{array}$ & $\begin{array}{c}0.2332 \\
1.66 \mathrm{E}-1 \\
\end{array}$ & $\begin{array}{c}0.3592 \\
3.41 \mathrm{E}-1 \\
\end{array}$ & $\begin{array}{c}0.2733 \\
1.83 \mathrm{E}-1 \\
\end{array}$ & \begin{tabular}{|r|}
$1.74 \mathrm{E}-4$ \\
$1.4 \mathrm{E}-7$ \\
\end{tabular} & \begin{tabular}{|c|}
$5.52 \mathrm{E}-4$ \\
$3.8 \mathrm{E}-6$ \\
\end{tabular} & $\begin{array}{l}5.94 \mathrm{E}-3 \\
3.3 \mathrm{E}-3 \\
\end{array}$ & $\begin{array}{l}1.40 \mathrm{E}-3 \\
8.1 \mathrm{E}-4\end{array}$ & $\begin{array}{l}1.72 \mathrm{E}-3 \\
9.7 \mathrm{E}-4 \\
\end{array}$ \\
\hline & $(20,10)$ & $\begin{array}{l}\text { M. } \\
\text { Std. }\end{array}$ & $\begin{array}{c}0.0658 \\
3.64 \mathrm{E}-2\end{array}$ & $\begin{array}{c}0.1635 \\
9.12 \mathrm{E}-2\end{array}$ & $\begin{array}{c}0.1018 \\
1.25 \mathrm{E}-1\end{array}$ & $\begin{array}{c}0.2168 \\
2.03 \mathrm{E}-1\end{array}$ & $\begin{array}{c}0.1778 \\
2.47 \mathrm{E}-1\end{array}$ & $\begin{array}{c}0.1959 \\
2.36 \mathrm{E}-1\end{array}$ & \begin{tabular}{|l|}
$1.84 \mathrm{E}-4$ \\
$6.1 \mathrm{E}-6$
\end{tabular} & \begin{tabular}{|c|}
$5.22 \mathrm{E}-4$ \\
$1.6 \mathrm{E}-7$
\end{tabular} & $\begin{array}{l}8.80 \mathrm{E}-3 \\
6.7 \mathrm{E}-3\end{array}$ & $\begin{array}{l}1.79 \mathrm{E}-4 \\
1.6 \mathrm{E}-4\end{array}$ & $\begin{array}{l}1.00 \mathrm{E}-4 \\
1.1 \mathrm{E}-4\end{array}$ \\
\hline \multirow{3}{*}{ FDA2 } & $(5,10)$ & $\begin{array}{l}\text { M. } \\
\text { Std. }\end{array}$ & $\begin{array}{c}0.0740 \\
3.53 \mathrm{E}-2 \\
\end{array}$ & $\begin{array}{c}0.1695 \\
6.51 \mathrm{E}-2 \\
\end{array}$ & $\begin{array}{c}0.1023 \\
1.09 \mathrm{E}-1 \\
\end{array}$ & $\begin{array}{c}0.2062 \\
1.66 \mathrm{E}-1 \\
\end{array}$ & $\begin{array}{c}0.1241 \\
4.72 \mathrm{E}-2 \\
\end{array}$ & $\begin{array}{c}0.2127 \\
1.49 \mathrm{E}-1 \\
\end{array}$ & \begin{tabular}{|l|}
$8.97 \mathrm{E}-3$ \\
$7.4 \mathrm{E}-04$ \\
\end{tabular} & \begin{tabular}{|c|}
$4.35 \mathrm{E}-2$ \\
$2.9 \mathrm{E}-5$ \\
\end{tabular} & $\begin{array}{l}3.46 \mathrm{E}-3 \\
8.7 \mathrm{E}-4\end{array}$ & $\begin{array}{l}4.01 \mathrm{E}-3 \\
1.0 \mathrm{E}-3 \\
\end{array}$ & $\begin{array}{l}3.27 \mathrm{E}-3 \\
8.6 \mathrm{E}-4\end{array}$ \\
\hline & $(10,10)$ & $\begin{array}{l}\text { M. } \\
\text { Std. }\end{array}$ & $\begin{array}{c}0.0842 \\
3.34 \mathrm{E}-2\end{array}$ & $\begin{array}{c}0.1906 \\
7.00 \mathrm{E}-2\end{array}$ & $\begin{array}{c}0.1200 \\
2.00 \mathrm{E}-1\end{array}$ & $\begin{array}{c}0.1965 \\
1.31 \mathrm{E}-1\end{array}$ & $\begin{array}{c}0.1243 \\
4.27 \mathrm{E}-2\end{array}$ & $\begin{array}{c}0.2528 \\
1.34 \mathrm{E}-1\end{array}$ & $\begin{array}{c}8.30 \mathrm{E}-3 \\
6.1 \mathrm{E}-4\end{array}$ & $\begin{array}{l}3.61 \mathrm{E}-2 \\
2.2 \mathrm{E}-6\end{array}$ & $\begin{array}{l}3.41 \mathrm{E}-3 \\
5.6 \mathrm{E}-4\end{array}$ & $\begin{array}{l}3.06 \mathrm{E}-3 \\
1.1 \mathrm{E}-3\end{array}$ & $\begin{array}{l}2.88 \mathrm{E}-3 \\
1.1 \mathrm{E}-3\end{array}$ \\
\hline & $(20,10)$ & $\begin{array}{c}\text { M. } \\
\text { Std. }\end{array}$ & $\begin{array}{c}0.0662 \\
3.63 \mathrm{E}-2 \\
\end{array}$ & $\begin{array}{c}0.1335 \\
4.02 \mathrm{E}-2 \\
\end{array}$ & $\begin{array}{c}0.0719 \\
9.86 \mathrm{E}-2\end{array}$ & $\begin{array}{c}0.1810 \\
1.88 \mathrm{E}-1\end{array}$ & $\begin{array}{c}0.0785 \\
3.37 \mathrm{E}-2\end{array}$ & $\begin{array}{c}0.1678 \\
1.44 \mathrm{E}-1\end{array}$ & $\begin{array}{c}7.92 \mathrm{E}-3 \\
1.9 \mathrm{E}-4\end{array}$ & \begin{tabular}{|c|}
$3.61 \mathrm{E}-2$ \\
$2.2 \mathrm{E}-3$ \\
\end{tabular} & $\begin{array}{l}7.27 \mathrm{E}-3 \\
2.0 \mathrm{E}-3\end{array}$ & $\begin{array}{l}1.95 \mathrm{E}-3 \\
6.3 \mathrm{E}-4\end{array}$ & $\begin{array}{l}2.54 \mathrm{E}-3 \\
8.1 \mathrm{E}-4\end{array}$ \\
\hline \multirow{3}{*}{ FDA3 } & $(5,10)$ & $\begin{array}{l}\text { M. } \\
\text { Std. }\end{array}$ & $\begin{array}{c}0.1428 \\
1.11 \mathrm{E}-1\end{array}$ & $\begin{array}{c}0.2685 \\
2.66 \mathrm{E}-1\end{array}$ & $\begin{array}{c}0.3142 \\
2.14 \mathrm{E}-1\end{array}$ & $\begin{array}{c}0.2250 \\
1.81 \mathrm{E}-1\end{array}$ & $\begin{array}{c}0.2925 \\
2.44 \mathrm{E}-1\end{array}$ & $\begin{array}{c}0.3493 \\
4.27 \mathrm{E}-1\end{array}$ & $\begin{array}{l}2.50 \mathrm{E}-2 \\
4.9 \mathrm{E}-5\end{array}$ & \begin{tabular}{|c|}
$9.52 \mathrm{E}-2$ \\
$7.0 \mathrm{E}-2$
\end{tabular} & $\begin{array}{l}2.47 \mathrm{E}-2 \\
2.2 \mathrm{E}-2\end{array}$ & $\begin{array}{l}9.26 \mathrm{E}-3 \\
3.4 \mathrm{E}-3\end{array}$ & $\begin{array}{l}1.52 \mathrm{E}-2 \\
5.6 \mathrm{E}-3\end{array}$ \\
\hline & $(10,10)$ & $\begin{array}{l}\text { M. } \\
\text { Std. }\end{array}$ & $\begin{array}{c}0.0914 \\
9.77 \mathrm{E}-2\end{array}$ & $\begin{array}{c}0.1429 \\
7.49 \mathrm{E}-2\end{array}$ & $\begin{array}{c}0.2072 \\
1.38 \mathrm{E}-1\end{array}$ & $\begin{array}{c}0.1994 \\
1.93 \mathrm{E}-1\end{array}$ & $\begin{array}{c}0.252 \\
2.75 \mathrm{E}-1\end{array}$ & $\begin{array}{c}0.2530 \\
3.05 \mathrm{E}-1\end{array}$ & $\begin{array}{l}3.32 \mathrm{E}-2 \\
9.7 \mathrm{E}-6\end{array}$ & $\begin{array}{c}9.50 \mathrm{E}-2 \\
6.2 \mathrm{E}-2 \\
\end{array}$ & $\begin{array}{l}2.83 \mathrm{E}-2 \\
2.8 \mathrm{E}-2\end{array}$ & $\begin{array}{l}5.54 \mathrm{E}-3 \\
2.9 \mathrm{E}-3\end{array}$ & $\begin{array}{l}3.96 \mathrm{E}-3 \\
1.7 \mathrm{E}-3 \\
\end{array}$ \\
\hline & $(20,10)$ & $\begin{array}{l}\text { M. } \\
\text { Std. }\end{array}$ & $\begin{array}{c}0.0749 \\
5.08 \mathrm{E}-2\end{array}$ & $\begin{array}{c}0.1349 \\
1.02 \mathrm{E}-1\end{array}$ & $\begin{array}{c}0.2286 \\
1.76 \mathrm{E}-1\end{array}$ & $\begin{array}{c}0.1409 \\
1.94 \mathrm{E}-1\end{array}$ & $\begin{array}{c}0.1442 \\
8.24 \mathrm{E}-2\end{array}$ & $\begin{array}{c}0.1361 \\
7.58 \mathrm{E}-2\end{array}$ & $\begin{array}{l}3.28 \mathrm{E}-2 \\
2.1 \mathrm{E}-5\end{array}$ & \begin{tabular}{|c|}
$1.02 \mathrm{E}-1$ \\
$6.9 \mathrm{E}-2$
\end{tabular} & $\begin{array}{l}1.35 \mathrm{E}-1 \\
9.8 \mathrm{E}-2\end{array}$ & $\begin{array}{l}1.48 \mathrm{E}-2 \\
1.0 \mathrm{E}-2\end{array}$ & $\begin{array}{l}8.36 \mathrm{E}-3 \\
5.7 \mathrm{E}-3\end{array}$ \\
\hline \multirow{3}{*}{ FDA4 } & $(5,10)$ & $\begin{array}{c}\text { M. } \\
\text { Std. }\end{array}$ & $\begin{array}{c}0.1523 \\
9.67 \mathrm{E}-2 \\
\end{array}$ & $\begin{array}{c}0.1578 \\
7.21 \mathrm{E}-2\end{array}$ & $\begin{array}{c}0.2114 \\
1.48 \mathrm{E}-1 \\
\end{array}$ & $\begin{array}{c}0.1866 \\
7.83 \mathrm{E}-2 \\
\end{array}$ & $\begin{array}{c}0.2335 \\
1.21 \mathrm{E}-1 \\
\end{array}$ & $\begin{array}{c}0.1702 \\
4.11 \mathrm{E}-2 \\
\end{array}$ & $\begin{array}{c}2.92 \mathrm{E}-3 \\
9.6 \mathrm{E}-5 \\
\end{array}$ & $\begin{array}{c}5.93 \mathrm{E}-2 \\
1.4 \mathrm{E}-3 \\
\end{array}$ & $\begin{array}{l}8.48 \mathrm{E}-4 \\
4.7 \mathrm{E}-4 \\
\end{array}$ & $\begin{array}{l}9.31 \mathrm{E}-4 \\
1.3 \mathrm{E}-4\end{array}$ & $\begin{array}{l}3.44 \mathrm{E}-4 \\
2.7 \mathrm{E}-5 \\
\end{array}$ \\
\hline & \begin{tabular}{|l|}
$(10,10)$ \\
\end{tabular} & $\begin{array}{l}\text { M. } \\
\text { Std. }\end{array}$ & $\begin{array}{c}0.1594 \\
5.77 \mathrm{E}-2 \\
\end{array}$ & $\begin{array}{c}0.1311 \\
4.03 \mathrm{E}-2 \\
\end{array}$ & $\begin{array}{c}0.1848 \\
1.75 \mathrm{E}-1 \\
\end{array}$ & $\begin{array}{c}0.1709 \\
5.15 \mathrm{E}-2 \\
\end{array}$ & $\begin{array}{c}0.2180 \\
1.05 \mathrm{E}-1 \\
\end{array}$ & $\begin{array}{c}0.1787 \\
8.33 \mathrm{E}-2 \\
\end{array}$ & \begin{tabular}{|c}
$1.81 \mathrm{E}-3$ \\
$5.0 \mathrm{E}-5$ \\
\end{tabular} & \begin{tabular}{|c}
$4.18 \mathrm{E}-2$ \\
$3.9 \mathrm{E}-3$ \\
\end{tabular} & $\begin{array}{l}1.28 \mathrm{E}-3 \\
5.3 \mathrm{E}-4\end{array}$ & $\begin{array}{l}5.78 \mathrm{E}-4 \\
4.1 \mathrm{E}-5 \\
\end{array}$ & $\begin{array}{l}1.43 \mathrm{E}-4 \\
8.2 \mathrm{E}-6\end{array}$ \\
\hline & \begin{tabular}{|l|}
$(20,10)$ \\
\end{tabular} & $\begin{array}{l}\text { M. } \\
\text { Std. }\end{array}$ & $\begin{array}{c}0.1336 \\
3.89 \mathrm{E}-2\end{array}$ & $\begin{array}{c}0.125 \\
4.06 \mathrm{E}-2\end{array}$ & $\begin{array}{c}0.1765 \\
2.02 \mathrm{E}-1\end{array}$ & $\begin{array}{c}0.1234 \\
2.36 \mathrm{E}-2\end{array}$ & $\begin{array}{c}0.1998 \\
9.90 \mathrm{E}-2\end{array}$ & $\begin{array}{c}0.1253 \\
2.66 \mathrm{E}-2\end{array}$ & $\begin{array}{l}1.92 \mathrm{E}-3 \\
2.0 \mathrm{E}-6\end{array}$ & $\begin{array}{c}4.19 \mathrm{E}-2 \\
2.2 \mathrm{E}-3\end{array}$ & $\begin{array}{l}5.62 \mathrm{E}-3 \\
1.8 \mathrm{E}-3\end{array}$ & $\begin{array}{l}.34 \mathrm{E}-4 \\
1.5 \mathrm{E}-5\end{array}$ & $\begin{array}{l}9.60 \mathrm{E}-5 \\
5.7 \mathrm{E}-6\end{array}$ \\
\hline \multirow{3}{*}{ FDA5 } & $(5,10)$ & $\begin{array}{c}\text { M. } \\
\text { Std. }\end{array}$ & $\begin{array}{c}0.2081 \\
6.47 \mathrm{E}-2 \\
\end{array}$ & $\begin{array}{c}0.2683 \\
8.65 \mathrm{E}-2 \\
\end{array}$ & $\begin{array}{c}0.2036 \\
7.28 \mathrm{E}-2 \\
\end{array}$ & $\begin{array}{c}0.2120 \\
1.05 \mathrm{E}-1 \\
\end{array}$ & $\begin{array}{c}0.1737 \\
4.19 \mathrm{E}-2 \\
\end{array}$ & $\begin{array}{c}0.2184 \\
1.01 \mathrm{E}-1 \\
\end{array}$ & \begin{tabular}{|c|}
$3.88 \mathrm{E}-2$ \\
$3.1 \mathrm{E}-4$ \\
\end{tabular} & \begin{tabular}{|c|}
$1.42 \mathrm{E}-1$ \\
$1.3 \mathrm{E}-2$ \\
\end{tabular} & $\begin{array}{l}6.62 \mathrm{E}-3 \\
1.4 \mathrm{E}-3 \\
\end{array}$ & $\begin{array}{l}1.05 \mathrm{E}-2 \\
1.8 \mathrm{E}-3 \\
\end{array}$ & $\begin{array}{l}8.16 \mathrm{E}-3 \\
1.2 \mathrm{E}-3 \\
\end{array}$ \\
\hline & \begin{tabular}{|l|}
$(10,10)$ \\
\end{tabular} & $\begin{array}{c}\text { M. } \\
\text { Std. }\end{array}$ & $\begin{array}{c}0.1892 \\
5.19 \mathrm{E}-2 \\
\end{array}$ & $\begin{array}{c}0.2369 \\
7.79 \mathrm{E}-2\end{array}$ & $\begin{array}{c}0.2305 \\
1.04 \mathrm{E}-1\end{array}$ & $\begin{array}{c}0.1862 \\
9.43 \mathrm{E}-2\end{array}$ & $\begin{array}{c}0.1752 \\
4.89 \mathrm{E}-2\end{array}$ & $\begin{array}{c}0.2140 \\
1.01 \mathrm{E}-1\end{array}$ & \begin{tabular}{|c|}
$2.87 \mathrm{E}-2$ \\
$2.1 \mathrm{E}-5$
\end{tabular} & \begin{tabular}{|c|}
$9.97 \mathrm{E}-2$ \\
$8.3 \mathrm{E}-3$
\end{tabular} & $\begin{array}{l}1.50 \mathrm{E}-2 \\
9.4 \mathrm{E}-3\end{array}$ & $\begin{array}{l}3.30 \mathrm{E}-3 \\
7.1 \mathrm{E}-4\end{array}$ & $\begin{array}{l}1.88 E-3 \\
2.8 E-4\end{array}$ \\
\hline & $(20,10)$ & $\begin{array}{l}\text { M. } \\
\text { Std. }\end{array}$ & $\begin{array}{c}0.1642 \\
6.06 \mathrm{E}-2 \\
\end{array}$ & $\begin{array}{c}0.1818 \\
5.76 \mathrm{E}-2 \\
\end{array}$ & $\begin{array}{c}0.1895 \\
8.11 \mathrm{E}-2 \\
\end{array}$ & $\begin{array}{c}0.1729 \\
9.00 \mathrm{E}-2 \\
\end{array}$ & $\begin{array}{c}0.1879 \\
4.56 \mathrm{E}-2 \\
\end{array}$ & $\begin{array}{c}0.1968 \\
7.64 \mathrm{E}-2 \\
\end{array}$ & $\begin{array}{c}5.10 \mathrm{E}-2 \\
1.8 \mathrm{E}-3 \\
\end{array}$ & \begin{tabular}{|c|}
$1.64 \mathrm{E}-1$ \\
$9.6 \mathrm{E}-3$ \\
\end{tabular} & $\begin{array}{l}2.35 \mathrm{E}-2 \\
1.0 \mathrm{E}-2 \\
\end{array}$ & $\begin{array}{l}1.77 \mathrm{E}-3 \\
3.2 \mathrm{E}-4\end{array}$ & $\begin{array}{l}\text { 7.48E-4 } \\
6.6 \mathrm{E}-5 \\
\end{array}$ \\
\hline \multirow{3}{*}{ dMOP1 } & $(5,10)$ & $\begin{array}{l}\text { M. } \\
\text { Std. }\end{array}$ & $\begin{array}{c}0.0589 \\
3.82 \mathrm{E}-2\end{array}$ & $\begin{array}{c}0.1857 \\
9.13 \mathrm{E}-2\end{array}$ & $\begin{array}{c}0.1269 \\
2.37 \mathrm{E}-1\end{array}$ & $\begin{array}{c}0.2237 \\
8.15 \mathrm{E}-2\end{array}$ & $\begin{array}{c}0.2345 \\
6.53 \mathrm{E}-2\end{array}$ & $\begin{array}{c}0.2421 \\
1.33 \mathrm{E}-1\end{array}$ & $\begin{array}{c}3.35 \mathrm{E}-3 \\
5.1 \mathrm{E}-7\end{array}$ & \begin{tabular}{|c|}
$3.35 \mathrm{E}-3$ \\
$1.0 \mathrm{E}-6$
\end{tabular} & $\begin{array}{l}.76 \mathrm{E}-4 \\
1.4 \mathrm{E}-5\end{array}$ & $\begin{array}{l}1.04 \mathrm{E}-4 \\
3.4 \mathrm{E}-6\end{array}$ & $\begin{array}{l}1.02 \mathrm{E}-4 \\
5.0 \mathrm{E}-6\end{array}$ \\
\hline & $(10,10)$ & $\begin{array}{l}\text { M. } \\
\text { Std. }\end{array}$ & $\begin{array}{c}.02 \mathrm{~L}-2 \\
0.0543 \\
5.52 \mathrm{E}-2\end{array}$ & $\begin{array}{c}0.1565 \\
7.39 \mathrm{E}-2\end{array}$ & $\begin{array}{c}0.0965 \\
2.18 \mathrm{E}-1\end{array}$ & $\begin{array}{c}0.3266 \\
1.99 \mathrm{E}-1\end{array}$ & $\begin{array}{c}0.2507 \\
8.15 \mathrm{E}-2\end{array}$ & $\begin{array}{c}0.2734 \\
1.46 \mathrm{E}-1\end{array}$ & \begin{tabular}{|c|}
$2.48 \mathrm{E}-3$ \\
$2.6 \mathrm{E}-7$
\end{tabular} & \begin{tabular}{|c|}
$1.59 \mathrm{E}-2$ \\
$1.3 \mathrm{E}-2$
\end{tabular} & $\begin{array}{l}1.97 \mathrm{E}-4 \\
2.2 \mathrm{E}-5\end{array}$ & $\begin{array}{l}8.40 \mathrm{E}-5 \\
1.7 \mathrm{E}-6\end{array}$ & $\begin{array}{l}6.46 \mathrm{E}-5 \\
2.5 \mathrm{E}-6\end{array}$ \\
\hline & $(20,10)$ & $\begin{array}{l}\text { M. } \\
\text { Std. }\end{array}$ & $\begin{array}{c}0.0252 \\
9.00 \mathrm{E}-3\end{array}$ & $\begin{array}{c}0.1145 \\
5.03 \mathrm{E}-2\end{array}$ & $\begin{array}{c}0.0690 \\
1.95 \mathrm{E}-1\end{array}$ & $\begin{array}{c}0.1938 \\
1.25 \mathrm{E}-1\end{array}$ & $\begin{array}{c}0.1204 \\
9.13 \mathrm{E}-2\end{array}$ & $\begin{array}{c}0.1606 \\
1.63 \mathrm{E}-1\end{array}$ & \begin{tabular}{|c|}
$3.47 \mathrm{E}-3$ \\
$1.1 \mathrm{E}-6$
\end{tabular} & \begin{tabular}{|c|}
$3.47 \mathrm{E}-3$ \\
$4.0 \mathrm{E}-7$
\end{tabular} & $\begin{array}{l}1.35 \mathrm{E}-4 \\
8.6 \mathrm{E}-6\end{array}$ & $\begin{array}{l}7.67 \mathrm{E}-5 \\
1.1 \mathrm{E}-6\end{array}$ & $\begin{array}{l}5.51 \mathrm{E}-5 \\
1.6 \mathrm{E}-6\end{array}$ \\
\hline \multirow{3}{*}{ dMOP2 } & $(5,10)$ & $\begin{array}{c}\text { M. } \\
\text { Std. }\end{array}$ & $\begin{array}{c}0.0494 \\
1.59 \mathrm{E}-2 \\
\end{array}$ & $\begin{array}{c}0.2258 \\
1.31 \mathrm{E}-1\end{array}$ & $\begin{array}{c}0.1265 \\
1.34 \mathrm{E}-1\end{array}$ & $\begin{array}{c}0.1302 \\
8.99 \mathrm{E}-2\end{array}$ & $\begin{array}{c}0.1311 \\
6.02 \mathrm{E}-2\end{array}$ & $\begin{array}{c}0.1505 \\
1.58 \mathrm{E}-1 \\
\end{array}$ & $\begin{array}{r}1.77 \mathrm{E}-4 \\
1.9 \mathrm{E}-6 \\
\end{array}$ & \begin{tabular}{|c|}
$1.72 \mathrm{E}-2$ \\
$1.7 \mathrm{E}-2$ \\
\end{tabular} & $\begin{array}{l}1.62 \mathrm{E}-3 \\
3.5 \mathrm{E}-3\end{array}$ & $\begin{array}{l}4.11 \mathrm{E}-3 \\
5.1 \mathrm{E}-3\end{array}$ & $\begin{array}{l}3.88 \mathrm{E}-3 \\
6.0 \mathrm{E}-3\end{array}$ \\
\hline & $(10,10)$ & $\begin{array}{c}\text { M. } \\
\text { Std. }\end{array}$ & $\begin{array}{c}0.0717 \\
4.20 \mathrm{E}-2\end{array}$ & $\begin{array}{c}0.1646 \\
8.01 \mathrm{E}-2\end{array}$ & $\begin{array}{c}0.1102 \\
1.00 \mathrm{E}-1\end{array}$ & $\begin{array}{c}0.1142 \\
8.98 \mathrm{E}-2\end{array}$ & $\begin{array}{c}0.1157 \\
6.03 \mathrm{E}-2\end{array}$ & $\begin{array}{c}0.1586 \\
1.33 \mathrm{E}-1\end{array}$ & \begin{tabular}{|r|}
$1.53 \mathrm{E}-4$ \\
$1.2 \mathrm{E}-7$
\end{tabular} & \begin{tabular}{|c|}
$1.50 \mathrm{E}-4$ \\
$1.9 \mathrm{E}-8$
\end{tabular} & $\begin{array}{l}3.70 \mathrm{E}-4 \\
8.6 \mathrm{E}-5\end{array}$ & $\begin{array}{l}5.64 \mathrm{E}-4 \\
3.8 \mathrm{E}-5\end{array}$ & $\begin{array}{l}6.44 \mathrm{E}-4 \\
7.8 \mathrm{E}-5\end{array}$ \\
\hline & $(20,10)$ & $\begin{array}{c}\text { M. } \\
\text { Std. }\end{array}$ & $\begin{array}{c}0.0261 \\
8.53 \mathrm{E}-3 \\
\end{array}$ & $\begin{array}{c}0.120 \\
8.70 \mathrm{E}-2\end{array}$ & $\begin{array}{c}0.0771 \\
1.12 \mathrm{E}-1 \\
\end{array}$ & $\begin{array}{c}0.0541 \\
4.82 \mathrm{E}-2 \\
\end{array}$ & $\begin{array}{c}0.0795 \\
4.89 \mathrm{E}-2 \\
\end{array}$ & $\begin{array}{c}0.0609 \\
4.64 \mathrm{E}-2 \\
\end{array}$ & \begin{tabular}{|c|}
$1.50 \mathrm{E}-4$ \\
$2.1 \mathrm{E}-7$ \\
\end{tabular} & \begin{tabular}{|c|}
$1.49 \mathrm{E}-4$ \\
$1.6 \mathrm{E}-7$ \\
\end{tabular} & $\begin{array}{l}2.81 \mathrm{E}-4 \\
1.1 \mathrm{E}-4\end{array}$ & $\begin{array}{l}2.35 \mathrm{E}-3 \\
9.6 \mathrm{E}-4\end{array}$ & $\begin{array}{l}2.36 \mathrm{E}-3 \\
8.9 \mathrm{E}-4\end{array}$ \\
\hline \multirow{3}{*}{ dMOP3 } & $(5,10)$ & $\begin{array}{c}\text { M. } \\
\text { Std. }\end{array}$ & $\begin{array}{r}0.0593 \\
3.10 \mathrm{E}-2\end{array}$ & $\begin{array}{c}0.1132 \\
8.72 \mathrm{E}-2\end{array}$ & $\begin{array}{c}0.1136 \\
8.84 \mathrm{E}-2\end{array}$ & $\begin{array}{c}0.0987 \\
7.16 \mathrm{E}-2\end{array}$ & $\begin{array}{c}0.1203 \\
4.29 \mathrm{E}-2\end{array}$ & $\begin{array}{c}0.0729 \\
3.87 \mathrm{E}-2\end{array}$ & \begin{tabular}{|c|}
$7.83 \mathrm{E}-2$ \\
$2.8 \mathrm{E}-3$
\end{tabular} & \begin{tabular}{|c|}
$8.85 \mathrm{E}-2$ \\
$3.7 \mathrm{E}-3$
\end{tabular} & $\begin{array}{l}1.10 \mathrm{E}-1 \\
1.6 \mathrm{E}-2\end{array}$ & $\begin{array}{l}2.18 \mathrm{E}-1 \\
7.2 \mathrm{E}-2\end{array}$ & $\begin{array}{l}8.56 \mathrm{E}-2 \\
3.3 \mathrm{E}-2\end{array}$ \\
\hline & \begin{tabular}{|l|}
$(10,10)$ \\
\end{tabular} & $\begin{array}{l}\text { M. } \\
\text { Std. }\end{array}$ & $\begin{array}{r}0.0683 \\
4.26 \mathrm{E}-2 \\
\end{array}$ & $\begin{array}{c}0.1431 \\
5.58 \mathrm{E}-2 \\
\end{array}$ & $\begin{array}{c}0.0736 \\
6.38 \mathrm{E}-2 \\
\end{array}$ & $\begin{array}{c}0.0897 \\
4.56 \mathrm{E}-2 \\
\end{array}$ & $\begin{array}{c}0.1057 \\
5.18 \mathrm{E}-2\end{array}$ & $\begin{array}{c}0.0850 \\
5.68 \mathrm{E}-2 \\
\end{array}$ & \begin{tabular}{|c|}
$1.59 \mathrm{E}-1$ \\
$8.8 \mathrm{E}-3$ \\
\end{tabular} & \begin{tabular}{|c|}
$1.88 \mathrm{E}-1$ \\
$6.9 \mathrm{E}-3$ \\
\end{tabular} & $\begin{array}{l}9.63 \mathrm{E}-2 \\
2.4 \mathrm{E}-2 \\
\end{array}$ & $\begin{array}{l}1.04 \mathrm{E}-1 \\
3.0 \mathrm{E}-2 \\
\end{array}$ & $\begin{array}{l}7.69 \mathrm{E}-2 \\
1.3 \mathrm{E}-2 \\
\end{array}$ \\
\hline & $(20,10)$ & $\begin{array}{l}\text { M. } \\
\text { Std. }\end{array}$ & $\begin{array}{r}0.0260 \\
5.56 \mathrm{E}-3\end{array}$ & $\begin{array}{c}0.0730 \\
4.91 \mathrm{E}-2\end{array}$ & $\begin{array}{c}0.0563 \\
6.87 \mathrm{E}-2\end{array}$ & $\begin{array}{c}0.0510 \\
3.52 \mathrm{E}-2\end{array}$ & $\begin{array}{c}0.0575 \\
3.22 \mathrm{E}-2\end{array}$ & $\begin{array}{c}0.0401 \\
2.57 \mathrm{E}-2\end{array}$ & $\begin{array}{c}6.38 \mathrm{E}-1 \\
1.8 \mathrm{E}-3\end{array}$ & $\begin{array}{c}9.05 \mathrm{E}-1 \\
3.3 \mathrm{E}-2\end{array}$ & $\begin{array}{l}1.58 \mathrm{E}-1 \\
3.1 \mathrm{E}-2\end{array}$ & $\begin{array}{l}3.47 \mathrm{E}-1 \\
4.1 \mathrm{E}-2\end{array}$ & $\begin{array}{l}1.62 \mathrm{E}-1 \\
5.1 \mathrm{E}-2\end{array}$ \\
\hline
\end{tabular}


TABLE IX. Mean and Standard Deviation Values of all MOEAs over IGD for FDA and dMOP Functions with Severe, Moderate and Slight Environmental Changes.

\begin{tabular}{|c|c|c|c|c|c|c|c|c|c|c|c|c|}
\hline \multirow[t]{2}{*}{ Prob. } & \multirow[t]{2}{*}{$\left(\tau_{t}, n_{t}\right)$} & \multirow[t]{2}{*}{ Values } & \multicolumn{5}{|c|}{ tested Algorithms of Jiang et al. [15] } & \multicolumn{5}{|c|}{ MOPSO-based Algorithms } \\
\hline & & & DNSGA-II & dCOEA & PPS & MOEA/D & SGEA & MOPSO & dMOPSO & pbMOPSO & Dynamic-MOPSO & DPb-MOPSO \\
\hline \multirow{3}{*}{ FDA1 } & $(5,10)$ & M. & $\begin{array}{c}6.40 \mathrm{E}-1 \\
9.8 \mathrm{E}-2\end{array}$ & $6.36 \mathrm{E}-2$ & $\begin{array}{l}2.08 \mathrm{E}-1 \\
84 \mathrm{E}-2\end{array}$ & $3.56 \mathrm{E}-1$ & $3.41 \mathrm{E}-2$ & 6.05E-5 & $1.68 \mathrm{E}-4$ & $1.13 \mathrm{E}-2$ & $8.77 \mathrm{E}-3$ & $1.68 \mathrm{E}-2$ \\
\hline & $(10,10)$ & $\begin{array}{l}\text { Std. } \\
\text { M. } \\
\text { Std. }\end{array}$ & $\begin{array}{l}9.8 \mathrm{E}-2 \\
5.82 \mathrm{E}-2 \\
3.8 \mathrm{E}-3\end{array}$ & $\begin{array}{c}1.1 \mathrm{E}-2 \\
4.13 \mathrm{E}-2 \\
6.5 \mathrm{E}-3\end{array}$ & $\begin{array}{c}8.4 \mathrm{E}-2 \\
4.27 \mathrm{E}-2 \\
1.9 \mathrm{E}-2\end{array}$ & $\begin{array}{c}4.9 \mathrm{E}-2 \\
1.21 \mathrm{E}-1 \\
1.1 \mathrm{E}-2\end{array}$ & $\begin{array}{l}8.0 \mathrm{E}-3 \\
1.48 \mathrm{E}-2 \\
2.0 \mathrm{E}-3\end{array}$ & $\begin{array}{c}2.0 \mathrm{E}-6 \\
5.19 \mathrm{E}-5 \\
1.1 \mathrm{E}-6\end{array}$ & $\begin{array}{c}8.8 \mathrm{E}-6 \\
1.45 \mathrm{E}-4 \\
5.1 \mathrm{E}-6\end{array}$ & $\begin{array}{l}.6 \mathrm{E}-3 \\
5.94 \mathrm{E}-3 \\
3.3 \mathrm{E}-3\end{array}$ & $\begin{array}{l}3.6 \mathrm{E}-3 \\
1.40 \mathrm{E}-3 \\
8.1 \mathrm{E}-4\end{array}$ & $\begin{array}{l}8.1 \mathrm{E}-3 \\
1.72 \mathrm{E}-3 \\
9.7 \mathrm{E}-4\end{array}$ \\
\hline & $(20,10)$ & $\begin{array}{l}\text { M. } \\
\text { Std. }\end{array}$ & $\begin{array}{l}4.14 \mathrm{E}-2 \\
4.2 \mathrm{E}-3\end{array}$ & $\begin{array}{l}2.39 \mathrm{E}-2 \\
2.2 \mathrm{E}-3\end{array}$ & $\begin{array}{l}1.62 \mathrm{E}-2 \\
7.9 \mathrm{E}-3\end{array}$ & $\begin{array}{l}4.04 \mathrm{E}-2 \\
2.2 \mathrm{E}-3\end{array}$ & $\begin{array}{c}7.55 \mathrm{E}-3 \\
1.4 \mathrm{E}-3\end{array}$ & $\begin{array}{c}3.90 \mathrm{E}-5 \\
4.8 \mathrm{E}-7\end{array}$ & $\begin{array}{l}1.11 \mathrm{E}-4 \\
2.4 \mathrm{E}-6\end{array}$ & $\begin{array}{l}8.80 \mathrm{E}-3 \\
6.7 \mathrm{E}-3\end{array}$ & $\begin{array}{l}1.79 \mathrm{E}-4 \\
1.6 \mathrm{E}-4\end{array}$ & $\begin{array}{l}1.00 \mathrm{E}-4 \\
1.1 \mathrm{E}-4\end{array}$ \\
\hline \multirow[t]{3}{*}{ FDA2 } & $(5,10)$ & $\begin{array}{l}\text { M. } \\
\text { Std. }\end{array}$ & $\begin{array}{l}2.85 \mathrm{E}-2 \\
2.4 \mathrm{E}-3 \\
\end{array}$ & $\begin{array}{c}7.28 \mathrm{E}-2 \\
3.8 \mathrm{E}-2\end{array}$ & $\begin{array}{c}8.13 \mathrm{E}-2 \\
3.0 \mathrm{E}-2\end{array}$ & $\begin{array}{c}8.40 \mathrm{E}-2 \\
1.3 \mathrm{E}-2\end{array}$ & $\begin{array}{c}1.50 \mathrm{E}-2 \\
1.6 \mathrm{E}-3\end{array}$ & $\begin{array}{c}7.00 \mathrm{E}-3 \\
1.2 \mathrm{E}-3\end{array}$ & $\begin{array}{c}4.18 \mathrm{E}-2 \\
1.7 \mathrm{E}-3\end{array}$ & $\begin{array}{l}3.46 \mathrm{E}-3 \\
8.7 \mathrm{E}-4\end{array}$ & $\begin{array}{l}4.01 \mathrm{E}-3 \\
1.0 \mathrm{E}-3\end{array}$ & $\begin{array}{l}\text { 3.27E-3 } \\
\text { 8.6E-4 }\end{array}$ \\
\hline & $(10,10)$ & $\begin{array}{l}\text { M. } \\
\text { Std. }\end{array}$ & $\begin{array}{l}1.68 \mathrm{E}-3 \\
9.0 \mathrm{E}-4\end{array}$ & $\begin{array}{c}4.73 \mathrm{E}-2 \\
3.3 \mathrm{E}-2\end{array}$ & $\begin{array}{c}6.35 \mathrm{E}-2 \\
1.0 \mathrm{E}-2\end{array}$ & $\begin{array}{c}3.38 \mathrm{E}-2 \\
8.8 \mathrm{E}-3\end{array}$ & $\begin{array}{c}9.11 \mathrm{E}-3 \\
6.3 \mathrm{E}-4\end{array}$ & $\begin{array}{c}4.16 \mathrm{E}-3 \\
4.7 \mathrm{E}-4\end{array}$ & $\begin{array}{c}2.32 \mathrm{E}-2 \\
1.4 \mathrm{E}-3\end{array}$ & $\begin{array}{l}3.41 \mathrm{E}-3 \\
5.6 \mathrm{E}-4\end{array}$ & $\begin{array}{l}3.06 \mathrm{E}-3 \\
1.1 \mathrm{E}-3\end{array}$ & $\begin{array}{l}2.88 \mathrm{E}-3 \\
1.1 \mathrm{E}-3\end{array}$ \\
\hline & $(20,10)$ & $\begin{array}{l}\text { M. } \\
\text { Std. }\end{array}$ & $\begin{array}{l}6.51 \mathrm{E}-3 \\
5.26 \mathrm{E}-4\end{array}$ & $\begin{array}{l}3.24 \mathrm{E}-2 \\
4.60 \mathrm{E}-2\end{array}$ & $\begin{array}{l}6.27 \mathrm{E}-2 \\
9.07 \mathrm{E}-3\end{array}$ & $\begin{array}{l}1.64 \mathrm{E}-2 \\
4.99 \mathrm{E}-3\end{array}$ & $\begin{array}{l}6.32 \mathrm{E}-3 \\
4.07 \mathrm{E}-4\end{array}$ & $\begin{array}{l}1.43 \mathrm{E}-3 \\
2.0 \mathrm{E}-5\end{array}$ & $\begin{array}{c}6.46 \mathrm{E}-3 \\
3.1 \mathrm{E}-4\end{array}$ & $\begin{array}{l}7.27 \mathrm{E}-3 \\
2.0 \mathrm{E}-3\end{array}$ & $\begin{array}{l}1.95 \mathrm{E}-3 \\
6.3 \mathrm{E}-4\end{array}$ & $\begin{array}{l}2.54 \mathrm{E}-3 \\
8.1 \mathrm{E}-4\end{array}$ \\
\hline \multirow[t]{3}{*}{ FDA3 } & $(5,10)$ & $\begin{array}{l}\text { M. } \\
\text { Std. }\end{array}$ & $\begin{array}{c}2.63 \mathrm{E}-1 \\
6.0 \mathrm{E}-2 \\
\end{array}$ & $\begin{array}{c}2.63 \mathrm{E}-1 \\
3.5 \mathrm{E}-2 \\
\end{array}$ & $\begin{array}{c}4.43 \mathrm{E}-1 \\
1.1 \mathrm{E}-1 \\
\end{array}$ & $\begin{array}{c}2.47 \mathrm{E}-1 \\
2.3 \mathrm{E}-2 \\
\end{array}$ & $\begin{array}{c}6.25 \mathrm{E}-2 \\
3.8 \mathrm{E}-2 \\
\end{array}$ & $\begin{array}{c}4.23 \mathrm{E}-2 \\
1.3 \mathrm{E}-4\end{array}$ & $\begin{array}{c}5.19 \mathrm{E}-2 \\
3.6 \mathrm{E}-2\end{array}$ & $\begin{array}{l}2.47 \mathrm{E}-2 \\
2.2 \mathrm{E}-2\end{array}$ & $\begin{array}{l}9.26 \mathrm{E}-3 \\
3.4 \mathrm{E}-3\end{array}$ & $\begin{array}{l}1.52 \mathrm{E}-2 \\
5.6 \mathrm{E}-3\end{array}$ \\
\hline & $(10,10)$ & $\begin{array}{l}\text { M. } \\
\text { Std. }\end{array}$ & $\begin{array}{c}1.08 \mathrm{E}-1 \\
3.3 \mathrm{E}-2 \\
\end{array}$ & $\begin{array}{c}1.95 \mathrm{E}-1 \\
3.2 \mathrm{E}-2 \\
\end{array}$ & $\begin{array}{c}2.19 \mathrm{E}-1 \\
1.8 \mathrm{E}-2 \\
\end{array}$ & $\begin{array}{c}1.30 \mathrm{E}-1 \\
2.5 \mathrm{E}-2 \\
\end{array}$ & $\begin{array}{c}4.03 \mathrm{E}-2 \\
2.9 \mathrm{E}-2 \\
\end{array}$ & $\begin{array}{c}3.97 \mathrm{E}-2 \\
3.6 \mathrm{E}-5\end{array}$ & $\begin{array}{c}5.68 \mathrm{E}-2 \\
4.4 \mathrm{E}-2 \\
\end{array}$ & $\begin{array}{l}2.83 \mathrm{E}-2 \\
2.8 \mathrm{E}-2\end{array}$ & $\begin{array}{l}5.54 \mathrm{E}-3 \\
2.9 \mathrm{E}-3\end{array}$ & $\begin{array}{l}3.96 \mathrm{E}-3 \\
1.7 \mathrm{E}-3\end{array}$ \\
\hline & $(20,10)$ & $\begin{array}{l}\text { M. } \\
\text { Std. }\end{array}$ & $\begin{array}{c}9.03 \mathrm{E}-2 \\
2.8 \mathrm{E}-3\end{array}$ & $\begin{array}{c}1.26 \mathrm{E}-1 \\
3.1 \mathrm{E}-2\end{array}$ & $\begin{array}{c}1.92 \mathrm{E}-1 \\
2.4 \mathrm{E}-2\end{array}$ & $\begin{array}{c}5.45 \mathrm{E}-2 \\
8.3 \mathrm{E}-3\end{array}$ & $\begin{array}{c}3.52 \mathrm{E}-2 \\
2.9 \mathrm{E}-2\end{array}$ & $\begin{array}{c}3.47 \mathrm{E}-2 \\
5.2 \mathrm{E}-6\end{array}$ & $\begin{array}{c}4.84 \mathrm{E}-2 \\
3.5 \mathrm{E}-2\end{array}$ & $\begin{array}{l}1.35 \mathrm{E}-1 \\
9.8 \mathrm{E}-2\end{array}$ & $\begin{array}{l}1.48 \mathrm{E}-2 \\
1.0 \mathrm{E}-2\end{array}$ & $\begin{array}{l}8.36 \mathrm{E}-3 \\
5.7 \mathrm{E}-3\end{array}$ \\
\hline \multirow[t]{3}{*}{ FDA4 } & $(5,10)$ & $\begin{array}{l}\text { M. } \\
\text { Std. }\end{array}$ & $\begin{array}{c}1.49 \mathrm{E}+0 \\
1.2 \mathrm{E}-1\end{array}$ & $\begin{array}{c}1.62 \mathrm{E}-1 \\
6.1 \mathrm{E}-3\end{array}$ & $\begin{array}{c}3.07 \mathrm{E}-1 \\
1.9 \mathrm{E}-2\end{array}$ & $\begin{array}{c}1.36 \mathrm{E}+0 \\
1.6 \mathrm{E}-1\end{array}$ & $\begin{array}{c}4.60 \mathrm{E}-1 \\
6.6 \mathrm{E}-2\end{array}$ & $\begin{array}{c}6.19 \mathrm{E}-4 \\
1.8 \mathrm{E}-5\end{array}$ & $\begin{array}{c}1.28 \mathrm{E}-2 \\
1.7 \mathrm{E}-3\end{array}$ & $\begin{array}{l}8.48 \mathrm{E}-4 \\
4.7 \mathrm{E}-4\end{array}$ & $\begin{array}{l}9.31 \mathrm{E}-4 \\
1.3 \mathrm{E}-4\end{array}$ & $\begin{array}{l}3.44 \mathrm{E}-4 \\
2.7 \mathrm{E}-5\end{array}$ \\
\hline & $(10,10)$ & $\begin{array}{l}\text { M. } \\
\text { Std. }\end{array}$ & $\begin{array}{c}7.63 \mathrm{E}-1 \\
4.4 \mathrm{E}-2 \\
\end{array}$ & $\begin{array}{c}1.24 \mathrm{E}-1 \\
4.5 \mathrm{E}-3\end{array}$ & $\begin{array}{c}2.11 \mathrm{E}-1 \\
2.0 \mathrm{E}-2\end{array}$ & $\begin{array}{c}5.77 \mathrm{E}-1 \\
5.4 \mathrm{E}-2\end{array}$ & $\begin{array}{c}1.83 \mathrm{E}-1 \\
6.6 \mathrm{E}-3\end{array}$ & $\begin{array}{c}6.20 \mathrm{E}-4 \\
1.6 \mathrm{E}-5\end{array}$ & $\begin{array}{c}1.25 \mathrm{E}-2 \\
1.8 \mathrm{E}-3\end{array}$ & $\begin{array}{l}1.28 \mathrm{E}-3 \\
5.3 \mathrm{E}-4\end{array}$ & $\begin{array}{l}5.78 \mathrm{E}-4 \\
4.1 \mathrm{E}-5 \\
\end{array}$ & $\begin{array}{l}1.43 \mathrm{E}-4 \\
8.2 \mathrm{E}-6\end{array}$ \\
\hline & $(20,10)$ & $\begin{array}{l}\text { M. } \\
\text { Std. }\end{array}$ & $\begin{array}{c}2.62 \mathrm{E}-1 \\
1.6 \mathrm{E}-2\end{array}$ & $\begin{array}{c}1.03 \mathrm{E}-1 \\
1.7 \mathrm{E}-3\end{array}$ & $\begin{array}{l}1.79 \mathrm{E}-1 \\
3.0 \mathrm{E}-3\end{array}$ & $\begin{array}{c}2.22 \mathrm{E}-1 \\
1.3 \mathrm{E}-2\end{array}$ & $\begin{array}{c}1.26 \mathrm{E}-1 \\
1.5 \mathrm{E}-3\end{array}$ & $\begin{array}{c}3.82 \mathrm{E}-4 \\
1.4 \mathrm{E}-5\end{array}$ & $\begin{array}{c}8.17 \mathrm{E}-3 \\
1.2 \mathrm{E}-3\end{array}$ & $\begin{array}{l}5.62 \mathrm{E}-3 \\
1.8 \mathrm{E}-3\end{array}$ & $\begin{array}{l}4.34 \mathrm{E}-4 \\
1.5 \mathrm{E}-5\end{array}$ & $\begin{array}{l}9.60 \mathrm{E}-5 \\
5.7 \mathrm{E}-6\end{array}$ \\
\hline \multirow[t]{3}{*}{ FDA5 } & $(5,10)$ & $\begin{array}{l}\text { M. } \\
\text { Std. }\end{array}$ & $\begin{array}{c}1.76 \mathrm{E}+0 \\
1.0 \mathrm{E}-1\end{array}$ & $\begin{array}{c}4.33 \mathrm{E}-1 \\
4.6 \mathrm{E}-2\end{array}$ & $\begin{array}{c}6.55 \mathrm{E}-1 \\
3.1 \mathrm{E}-2\end{array}$ & $\begin{array}{c}1.57 \mathrm{E}+0 \\
1.3 \mathrm{E}-1\end{array}$ & $\begin{array}{c}5.23 \mathrm{E}-1 \\
3.3 \mathrm{E}-2\end{array}$ & $\begin{array}{c}2.50 \mathrm{E}-2 \\
1.8 \mathrm{E}-4\end{array}$ & $\begin{array}{c}7.21 \mathrm{E}-2 \\
6.0 \mathrm{E}-3\end{array}$ & $\begin{array}{l}6.62 \mathrm{E}-3 \\
1.4 \mathrm{E}-3\end{array}$ & $\begin{array}{l}1.05 \mathrm{E}-2 \\
1.8 \mathrm{E}-3\end{array}$ & $\begin{array}{l}8.16 \mathrm{E}-3 \\
1.2 \mathrm{E}-3\end{array}$ \\
\hline & $(10,10)$ & $\begin{array}{l}\text { M. } \\
\text { Std. }\end{array}$ & $\begin{array}{c}1.02 \mathrm{E}+0 \\
5.4 \mathrm{E}-2\end{array}$ & $\begin{array}{c}3.62 \mathrm{E}-1 \\
4.0 \mathrm{E}-2\end{array}$ & $\begin{array}{c}4.80 \mathrm{E}-1 \\
3.5 \mathrm{E}-2\end{array}$ & $\begin{array}{c}8.19 \mathrm{E}-1 \\
6.0 \mathrm{E}-2\end{array}$ & $\begin{array}{c}3.62 \mathrm{E}-1 \\
8.5 \mathrm{E}-3\end{array}$ & $\begin{array}{l}2.16 \mathrm{E}-2 \\
2.0 \mathrm{E}-4\end{array}$ & $\begin{array}{c}6.08 \mathrm{E}-2 \\
3.6 \mathrm{E}-3\end{array}$ & $\begin{array}{l}1.50 \mathrm{E}-2 \\
9.4 \mathrm{E}-3\end{array}$ & $\begin{array}{l}3.30 \mathrm{E}-3 \\
7.1 \mathrm{E}-4\end{array}$ & $\begin{array}{l}1.88 E-3 \\
2.8 E-4\end{array}$ \\
\hline & $(20,10)$ & $\begin{array}{l}\text { M. } \\
\text { Std. }\end{array}$ & $\begin{array}{c}4.88 \mathrm{E}-1 \\
1.2 \mathrm{E}-2\end{array}$ & $\begin{array}{c}3.10 \mathrm{E}-1 \\
2.7 \mathrm{E}-2\end{array}$ & $\begin{array}{c}3.71 \mathrm{E}-1 \\
1.2 \mathrm{E}-2\end{array}$ & $\begin{array}{c}4.07 \mathrm{E}-1 \\
1.4 \mathrm{E}-2\end{array}$ & $\begin{array}{c}3.09 \mathrm{E}-1 \\
2.2 \mathrm{E}-3\end{array}$ & $\begin{array}{c}1.42 \mathrm{E}-2 \\
1.3 \mathrm{E}-4\end{array}$ & $\begin{array}{c}3.89 \mathrm{E}-2 \\
3.5 \mathrm{E}-3\end{array}$ & $\begin{array}{l}2.35 \mathrm{E}-2 \\
1.0 \mathrm{E}-2\end{array}$ & $\begin{array}{l}1.77 \mathrm{E}-3 \\
3.2 \mathrm{E}-4\end{array}$ & $\begin{array}{l}\text { 7.48E-4 } \\
6.6 \mathrm{E}-5\end{array}$ \\
\hline \multirow[t]{3}{*}{ dMOP1 } & $(5,10)$ & $\begin{array}{l}\text { M. } \\
\text { Std. }\end{array}$ & $\begin{array}{c}1.31 \mathrm{E}-1 \\
1.1 \mathrm{E}-2\end{array}$ & $\begin{array}{c}6.95 \mathrm{E}-2 \\
1.4 \mathrm{E}-2\end{array}$ & $\begin{array}{c}4.15 \mathrm{E}-1 \\
7.4 \mathrm{E}-1\end{array}$ & $\begin{array}{c}1.36 \mathrm{E}-2 \\
9.0 \mathrm{E}-3\end{array}$ & $\begin{array}{c}1.12 \mathrm{E}-2 \\
8.1 \mathrm{E}-3\end{array}$ & $\begin{array}{c}4.06 \mathrm{E}-3 \\
2.8 \mathrm{E}-7\end{array}$ & $\begin{array}{c}4.39 \mathrm{E}-3 \\
1.8 \mathrm{E}-3\end{array}$ & $\begin{array}{l}1.76 \mathrm{E}-4 \\
1.4 \mathrm{E}-5\end{array}$ & $\begin{array}{l}1.04 \mathrm{E}-4 \\
3.4 \mathrm{E}-6\end{array}$ & $\begin{array}{l}1.02 E-4 \\
5.0 E-6\end{array}$ \\
\hline & $(10,10)$ & $\begin{array}{l}\text { M. } \\
\text { Std. }\end{array}$ & $\begin{array}{c}8.83 \mathrm{E}-3 \\
5.0 \mathrm{E}-3 \\
\end{array}$ & $\begin{array}{c}3.93 \mathrm{E}-2 \\
6.2 \mathrm{E}-3 \\
\end{array}$ & $\begin{array}{c}5.09 \mathrm{E}-2 \\
9.3 \mathrm{E}-2 \\
\end{array}$ & $\begin{array}{c}9.39 \mathrm{E}-3 \\
4.3 \mathrm{E}-3 \\
\end{array}$ & $\begin{array}{c}8.24 \mathrm{E}-3 \\
5.3 \mathrm{E}-3 \\
\end{array}$ & $\begin{array}{c}2.02 \mathrm{E}-3 \\
2.2 \mathrm{E}-7\end{array}$ & $\begin{array}{c}2.29 \mathrm{E}-3 \\
1.4 \mathrm{E}-3 \\
\end{array}$ & $\begin{array}{l}1.97 \mathrm{E}-4 \\
2.2 \mathrm{E}-5\end{array}$ & $\begin{array}{l}8.40 \mathrm{E}-5 \\
1.7 \mathrm{E}-6 \\
\end{array}$ & $\begin{array}{l}6.46 E-5 \\
2.5 E-6 \\
\end{array}$ \\
\hline & $(20,10)$ & $\begin{array}{l}\text { M. } \\
\text { Std. }\end{array}$ & $\begin{array}{c}7.39 \mathrm{E}-3 \\
3.2 \mathrm{E}-3\end{array}$ & $\begin{array}{l}1.88 \mathrm{E}-2 \\
2.3 \mathrm{E}-3\end{array}$ & $\begin{array}{c}4.39 \mathrm{E}-2 \\
8.4 \mathrm{E}-2\end{array}$ & $\begin{array}{c}7.17 \mathrm{E}-3 \\
2.7 \mathrm{E}-3\end{array}$ & $\begin{array}{c}6.54 \mathrm{E}-3 \\
3.0 \mathrm{E}-3\end{array}$ & $\begin{array}{c}2.71 \mathrm{E}-3 \\
1.3 \mathrm{E}-7\end{array}$ & $\begin{array}{c}2.71 \mathrm{E}-3 \\
1.0 \mathrm{E}-7\end{array}$ & $\begin{array}{l}1.35 \mathrm{E}-4 \\
8.6 \mathrm{E}-6\end{array}$ & $\begin{array}{l}7.67 \mathrm{E}-5 \\
1.1 \mathrm{E}-6\end{array}$ & $\begin{array}{l}5.51 \mathrm{E}-5 \\
1.6 \mathrm{E}-6\end{array}$ \\
\hline \multirow[t]{3}{*}{ dMOP2 } & $(5,10)$ & $\begin{array}{l}\text { M. } \\
\text { Std. }\end{array}$ & $\begin{array}{c}6.87 \mathrm{E}-1 \\
7.5 \mathrm{E}-2\end{array}$ & $\begin{array}{l}1.20 \mathrm{E}-1 \\
2.0 \mathrm{E}-2\end{array}$ & $\begin{array}{c}1.56 \mathrm{E}-1 \\
1.8 \mathrm{E}-2\end{array}$ & $\begin{array}{c}4.91 \mathrm{E}-1 \\
4.1 \mathrm{E}-2\end{array}$ & $\begin{array}{c}3.02 \mathrm{E}-2 \\
3.4 \mathrm{E}-3\end{array}$ & $\begin{array}{c}1.59 \mathrm{E}-3 \\
6.0 \mathrm{E}-7\end{array}$ & $\begin{array}{c}4.19 \mathrm{E}-3 \\
6.6 \mathrm{E}-3\end{array}$ & $\begin{array}{l}1.62 \mathrm{E}-3 \\
3.5 \mathrm{E}-3\end{array}$ & $\begin{array}{l}4.11 \mathrm{E}-3 \\
5.1 \mathrm{E}-3\end{array}$ & $\begin{array}{l}3.88 \mathrm{E}-3 \\
6.0 \mathrm{E}-3\end{array}$ \\
\hline & $(10,10)$ & $\begin{array}{l}\text { M. } \\
\text { Std. }\end{array}$ & $\begin{array}{c}1.18 \mathrm{E}-1 \\
9.4 \mathrm{E}-3\end{array}$ & $\begin{array}{c}7.32 \mathrm{E}-2 \\
8.9 \mathrm{E}-3\end{array}$ & $\begin{array}{c}4.28 \mathrm{E}-1 \\
1.7 \mathrm{E}-2 \\
\end{array}$ & $\begin{array}{c}1.88 \mathrm{E}-1 \\
1.9 \mathrm{E}-2 \\
\end{array}$ & $\begin{array}{c}1.21 \mathrm{E}-2 \\
5.7 \mathrm{E}-4\end{array}$ & $\begin{array}{l}6.33 \mathrm{E}-4 \\
2.0 \mathrm{E}-6\end{array}$ & $\begin{array}{c}2.95 \mathrm{E}-3 \\
8.7 \mathrm{E}-3\end{array}$ & $\begin{array}{l}3.70 \mathrm{E}-4 \\
8.6 \mathrm{E}-5\end{array}$ & $\begin{array}{l}5.64 \mathrm{E}-4 \\
3.8 \mathrm{E}-5\end{array}$ & $\begin{array}{l}6.44 \mathrm{E}-4 \\
7.8 \mathrm{E}-5\end{array}$ \\
\hline & $(20,10)$ & $\begin{array}{l}\text { M. } \\
\text { Std. }\end{array}$ & $\begin{array}{l}1.57 \mathrm{E}-1 \\
6.70 \mathrm{E}-4\end{array}$ & $\begin{array}{l}3.46 \mathrm{E}-2 \\
4.32 \mathrm{E}-3 \\
\end{array}$ & $\begin{array}{l}2.02 \mathrm{E}-2 \\
2.49 \mathrm{E}-3\end{array}$ & $\begin{array}{l}5.63 \mathrm{E}-2 \\
3.91 \mathrm{E}-3 \\
\end{array}$ & $\begin{array}{l}6.32 \mathrm{E}-3 \\
1.74 \mathrm{E}-4 \\
\end{array}$ & $\begin{array}{l}1.92 \mathrm{E}-3 \\
3.7 \mathrm{E}-7 \\
\end{array}$ & $\begin{array}{c}2.70 \mathrm{E}-3 \\
4.2 \mathrm{E}-3 \\
\end{array}$ & $\begin{array}{l}2.81 E-4 \\
1.1 E-4\end{array}$ & $\begin{array}{l}2.35 \mathrm{E}-3 \\
9.6 \mathrm{E}-4\end{array}$ & $\begin{array}{l}2.36 \mathrm{E}-3 \\
8.9 \mathrm{E}-4\end{array}$ \\
\hline \multirow{3}{*}{ dMOP3 } & $(5,10)$ & $\begin{array}{l}\text { M. } \\
\text { Std. }\end{array}$ & $\begin{array}{c}5.62 \mathrm{E}-1 \\
3.9 \mathrm{E}-2\end{array}$ & $\begin{array}{c}4.95 \mathrm{E}-2 \\
4.8 \mathrm{E}-3\end{array}$ & $\begin{array}{c}1.76 \mathrm{E}-1 \\
8.0 \mathrm{E}-2\end{array}$ & $\begin{array}{c}3.42 \mathrm{E}-1 \\
1.9 \mathrm{E}-2\end{array}$ & $\begin{array}{l}1.81 \mathrm{E}-1 \\
9.6 \mathrm{E}-2\end{array}$ & $\begin{array}{c}9.13 \mathrm{E}-1 \\
2.9 \mathrm{E}-1\end{array}$ & $\begin{array}{c}1.19 \mathrm{E}+0 \\
5.2 \mathrm{E}-2\end{array}$ & $\begin{array}{l}1.10 \mathrm{E}-1 \\
1.6 \mathrm{E}-2\end{array}$ & $\begin{array}{l}2.18 \mathrm{E}-1 \\
7.2 \mathrm{E}-2\end{array}$ & $\begin{array}{l}8.56 \mathrm{E}-2 \\
3.3 \mathrm{E}-2\end{array}$ \\
\hline & $(10,10)$ & $\begin{array}{l}\text { M. } \\
\text { Std. }\end{array}$ & $\begin{array}{c}2.00 \mathrm{E}-1 \\
1.5 \mathrm{E}-2\end{array}$ & $\begin{array}{c}2.95 \mathrm{E}-2 \\
2.4 \mathrm{E}-3\end{array}$ & $\begin{array}{c}1.13 \mathrm{E}-1 \\
1.2 \mathrm{E}-2\end{array}$ & $\begin{array}{c}1.68 \mathrm{E}-1 \\
1.0 \mathrm{E}-2\end{array}$ & $\begin{array}{c}1.32 \mathrm{E}-1 \\
1.3 \mathrm{E}-2\end{array}$ & $\begin{array}{l}2.67 \mathrm{E}-1 \\
2.0 \mathrm{E}-2\end{array}$ & $\begin{array}{c}2.95 \mathrm{E}-1 \\
4.2 \mathrm{E}-3\end{array}$ & $\begin{array}{l}9.63 \mathrm{E}-2 \\
2.4 \mathrm{E}-2\end{array}$ & $\begin{array}{l}1.04 \mathrm{E}-1 \\
3.0 \mathrm{E}-2\end{array}$ & $\begin{array}{l}7.69 \mathrm{E}-2 \\
1.3 \mathrm{E}-2\end{array}$ \\
\hline & $(20,10)$ & $\begin{array}{l}\text { M. } \\
\text { Std. }\end{array}$ & $\begin{array}{l}1.07 \mathrm{E}-1 \\
8.50 \mathrm{E}-3\end{array}$ & $\begin{array}{c}1.63 \mathrm{E}-2 \\
1.71 \mathrm{E}-3\end{array}$ & $\begin{array}{l}8.99 \mathrm{E}-2 \\
6.74 \mathrm{E}-3\end{array}$ & $\begin{array}{l}6.27 \mathrm{E}-2 \\
4.37 \mathrm{E}-3\end{array}$ & $\begin{array}{l}8.15 \mathrm{E}-2 \\
1.25 \mathrm{E}-2 \\
\end{array}$ & $\begin{array}{c}5.04 \mathrm{E}+0 \\
2.7 \mathrm{E}+0 \\
\end{array}$ & $\begin{array}{c}8.88 \mathrm{E}+0 \\
1.9 \mathrm{E}-1 \\
\end{array}$ & $\begin{array}{l}1.58 \mathrm{E}-1 \\
3.1 \mathrm{E}-2\end{array}$ & $\begin{array}{l}3.47 \mathrm{E}-1 \\
4.1 \mathrm{E}-2\end{array}$ & $\begin{array}{l}1.62 \mathrm{E}-1 \\
5.1 \mathrm{E}-2\end{array}$ \\
\hline
\end{tabular}


TABLE X. Mean and Standard Deviation Values of all MOEAs over HVD for FDA and dMOP Functions with Severe, Moderate and Slight Changes.

\begin{tabular}{|c|c|c|c|c|c|c|c|c|c|c|c|c|}
\hline \multirow[t]{2}{*}{ Prob. } & \multirow[t]{2}{*}{$(\tau t, n t)$} & \multirow[t]{2}{*}{ Val. } & \multicolumn{5}{|c|}{ Tested Algorithms of Jiang et al. [15] } & \multicolumn{4}{|c|}{ MOPSO-based Algorithms } & \multirow[b]{2}{*}{ DPb-MOPSO } \\
\hline & & & DNSGA-II & dCOEA & PPS & MOEA/D & SGEA & MOPSO & dMOPSO & pbMOPSO & Dynamic-MOPSO & \\
\hline \multirow{3}{*}{ FDA1 } & $(5,10)$ & $\begin{array}{l}\text { M. } \\
\text { Std. }\end{array}$ & $\begin{array}{c}8.70 \mathrm{E}-1 \\
7.5 \mathrm{E}-2\end{array}$ & $\begin{array}{l}1.25 \mathrm{E}-1 \\
2.4 \mathrm{E}-2\end{array}$ & $\begin{array}{c}3.87 \mathrm{E}-1 \\
1.0 \mathrm{E}-1\end{array}$ & $\begin{array}{l}7.70 \mathrm{E}-1 \\
9.4 \mathrm{E}-2\end{array}$ & $\begin{array}{l}8.14 \mathrm{E}-2 \\
2.0 \mathrm{E}-2\end{array}$ & $\begin{array}{l}\text { 3.83E-3 } \\
1.6 \mathrm{E}-4\end{array}$ & $\begin{array}{c}4.48 \mathrm{E}-3 \\
6.3 \mathrm{E}-5\end{array}$ & $\begin{array}{l}1.14 \mathrm{E}-1 \\
5.2 \mathrm{E}-2\end{array}$ & $\begin{array}{l}1.51 \mathrm{E}-1 \\
5.2 \mathrm{E}-2\end{array}$ & $\begin{array}{l}1.56 \mathrm{E}-1 \\
6.9 \mathrm{E}-2\end{array}$ \\
\hline & $(10,10)$ & $\begin{array}{l}\text { M. } \\
\text { Std. }\end{array}$ & $\begin{array}{l}1.36 \mathrm{E}-1 \\
1.7 \mathrm{E}-2 \\
\end{array}$ & $\begin{array}{l}8.52 \mathrm{E}-2 \\
2.0 \mathrm{E}-2 \\
\end{array}$ & $\begin{array}{c}2.97 \mathrm{E}-1 \\
1.6 \mathrm{E}-2\end{array}$ & $\begin{array}{l}2.88 \mathrm{E}-1 \\
2.9 \mathrm{E}-2\end{array}$ & $\begin{array}{c}3.81 \mathrm{E}-2 \\
1.4 \mathrm{E}-2 \\
\end{array}$ & $\begin{array}{c}4.14 \mathrm{E}-3 \\
6.4 \mathrm{E}-5\end{array}$ & $\begin{array}{c}4.56 \mathrm{E}-3 \\
4.0 \mathrm{E}-5 \\
\end{array}$ & $\begin{array}{l}1.03 \mathrm{E}-1 \\
6.0 \mathrm{E}-2\end{array}$ & $\begin{array}{l}6.22 \mathrm{E}-2 \\
3.3 \mathrm{E}-2\end{array}$ & $\begin{array}{l}6.65 \mathrm{E}-2 \\
3.7 \mathrm{E}-2\end{array}$ \\
\hline & $(20,10)$ & $\begin{array}{l}\text { M. } \\
\text { Std. }\end{array}$ & $\begin{array}{c}3.55 \mathrm{E}-2 \\
1.3 \mathrm{E}-2 \\
\end{array}$ & $\begin{array}{l}5.46 \mathrm{E}-2 \\
1.6 \mathrm{E}-2 \\
\end{array}$ & $\begin{array}{c}2.84 \mathrm{E}-1 \\
1.5 \mathrm{E}-2 \\
\end{array}$ & $\begin{array}{l}1.34 \mathrm{E}-1 \\
9.2 \mathrm{E}-3 \\
\end{array}$ & $\begin{array}{l}2.02 \mathrm{E}-2 \\
1.2 \mathrm{E}-2 \\
\end{array}$ & $\begin{array}{l}\text { 4.30E-3 } \\
3.6 \mathrm{E}-5\end{array}$ & $\begin{array}{l}4.65 \mathrm{E}-3 \\
1.7 \mathrm{E}-5\end{array}$ & $\begin{array}{l}8.36 \mathrm{E}-2 \\
6.9 \mathrm{E}-2\end{array}$ & $\begin{array}{l}6.67 \mathrm{E}-3 \\
7.7 \mathrm{E}-3\end{array}$ & $\begin{array}{l}6.57 \mathrm{E}-3 \\
1.3 \mathrm{E}-2\end{array}$ \\
\hline \multirow[t]{3}{*}{ FDA2 } & $(5,10)$ & $\begin{array}{l}\text { M. } \\
\text { Std. }\end{array}$ & $\begin{array}{l}4.71 \mathrm{E}-2 \\
1.4 \mathrm{E}-2 \\
\end{array}$ & $\begin{array}{l}1.85 \mathrm{E}-1 \\
6.4 \mathrm{E}-2 \\
\end{array}$ & $\begin{array}{l}3.21 \mathrm{E}-1 \\
6.7 \mathrm{E}-2 \\
\end{array}$ & $\begin{array}{l}1.30 \mathrm{E}-1 \\
2.5 \mathrm{E}-2 \\
\end{array}$ & $\begin{array}{c}2.54 \mathrm{E}-2 \\
1.3 \mathrm{E}-2 \\
\end{array}$ & $\begin{array}{c}8.99 \mathrm{E}+0 \\
8.5 \mathrm{E}-1 \\
\end{array}$ & $\begin{array}{c}9.96 \mathrm{E}+0 \\
1.4 \mathrm{E}+0 \\
\end{array}$ & $\begin{array}{l}6.75 \mathrm{E}+0 \\
9.9 \mathrm{E}+0 \\
\end{array}$ & $\begin{array}{l}3.04 \mathrm{E}+0 \\
2.9 \mathrm{E}+0 \\
\end{array}$ & $\begin{array}{l}8.83 \mathrm{E}+0 \\
9.7 \mathrm{E}+0 \\
\end{array}$ \\
\hline & $(10,10)$ & $\begin{array}{l}\text { M. } \\
\text { Std. }\end{array}$ & $\begin{array}{l}2.05 \mathrm{E}-2 \\
1.4 \mathrm{E}-2\end{array}$ & $\begin{array}{l}1.24 \mathrm{E}-1 \\
4.6 \mathrm{E}-2\end{array}$ & $\begin{array}{c}2.66 \mathrm{E}-1 \\
1.4 \mathrm{E}-2\end{array}$ & $\begin{array}{l}6.29 \mathrm{E}-2 \\
1.8 \mathrm{E}-2\end{array}$ & $\begin{array}{r}1.67 \mathrm{E}-2 \\
1.4 \mathrm{E}-2\end{array}$ & $\begin{array}{c}8.54 \mathrm{E}+0 \\
3.2 \mathrm{E}-1\end{array}$ & $\begin{array}{c}9.72 \mathrm{E}+0 \\
1.4 \mathrm{E}+0\end{array}$ & $\begin{array}{l}1.60 \mathrm{E}+1 \\
6.4 \mathrm{E}+0\end{array}$ & $\begin{array}{l}2.55 \mathrm{E}+0 \\
1.6 \mathrm{E}+0\end{array}$ & $\begin{array}{l}1.29 \mathrm{E}+1 \\
1.5 \mathrm{E}+1\end{array}$ \\
\hline & $(20,10)$ & $\begin{array}{l}\text { M. } \\
\text { Std. }\end{array}$ & $\begin{array}{l}1.33 \mathrm{E}-2 \\
1.4 \mathrm{E}-2\end{array}$ & $\begin{array}{l}8.64 \mathrm{E}-2 \\
7.0 \mathrm{E}-2\end{array}$ & $\begin{array}{c}2.55 \mathrm{E}-1 \\
9.4 \mathrm{E}-3\end{array}$ & $\begin{array}{c}3.24 \mathrm{E}-2 \\
1.4 \mathrm{E}-2\end{array}$ & $\begin{array}{r}1.23 \mathrm{E}-2 \\
1.4 \mathrm{E}-2\end{array}$ & $\begin{array}{c}8.43 \mathrm{E}+0 \\
1.8 \mathrm{E}-2\end{array}$ & $\begin{array}{c}8.19 \mathrm{E}+0 \\
1.1 \mathrm{E}+0\end{array}$ & $\begin{array}{l}8.80 \mathrm{E}+0 \\
1.3 \mathrm{E}+1\end{array}$ & $\begin{array}{l}1.23 \mathrm{E}+0 \\
7.4 \mathrm{E}-1\end{array}$ & $\begin{array}{l}7.70 \mathrm{E}+0 \\
8.8 \mathrm{E}+0\end{array}$ \\
\hline \multirow[t]{3}{*}{ FDA3 } & $(5,10)$ & $\begin{array}{l}\text { M. } \\
\text { Std. }\end{array}$ & $\begin{array}{c}1.54 \mathrm{E}+0 \\
1.6 \mathrm{E}-1\end{array}$ & $\begin{array}{c}1.45 \mathrm{E}+0 \\
8.5 \mathrm{E}-2 \\
\end{array}$ & $\begin{array}{c}1.75 \mathrm{E}+0 \\
1.8 \mathrm{E}-1 \\
\end{array}$ & $\begin{array}{l}1.66 \mathrm{E}+0 \\
7.8 \mathrm{E}-2\end{array}$ & $\begin{array}{l}9.80 \mathrm{E}-1 \\
1.0 \mathrm{E}-1\end{array}$ & $\begin{array}{l}4.86 \mathrm{E}-1 \\
8.2 \mathrm{E}-3 \\
\end{array}$ & $\begin{array}{c}4.27 \mathrm{E}-1 \\
2.6 \mathrm{E}-1\end{array}$ & $\begin{array}{l}2.62 \mathrm{E}-1 \\
1.6 \mathrm{E}-1\end{array}$ & $\begin{array}{l}1.13 \mathrm{E}-1 \\
6.3 \mathrm{E}-2\end{array}$ & $\begin{array}{l}9.59 \mathrm{E}-2 \\
6.4 \mathrm{E}-2 \\
\end{array}$ \\
\hline & $(10,10)$ & $\begin{array}{l}\text { M. } \\
\text { Std. }\end{array}$ & $\begin{array}{c}1.09 \mathrm{E}+0 \\
9.9 \mathrm{E}-2\end{array}$ & $\begin{array}{c}1.32 \mathrm{E}+0 \\
7.7 \mathrm{E}-2 \\
\end{array}$ & $\begin{array}{c}1.16 \mathrm{E}+0 \\
4.6 \mathrm{E}-2 \\
\end{array}$ & $\begin{array}{l}1.12 \mathrm{E}+0 \\
9.3 \mathrm{E}-2 \\
\end{array}$ & $\begin{array}{l}9.24 \mathrm{E}-1 \\
8.2 \mathrm{E}-2 \\
\end{array}$ & $\begin{array}{l}5.62 \mathrm{E}-1 \\
6.5 \mathrm{E}-4 \\
\end{array}$ & $\begin{array}{c}5.27 \mathrm{E}-1 \\
1.9 \mathrm{E}-1 \\
\end{array}$ & $\begin{array}{l}3.21 \mathrm{E}-1 \\
2.3 \mathrm{E}-1\end{array}$ & $\begin{array}{l}8.48 \mathrm{E}-2 \\
5.0 \mathrm{E}-2\end{array}$ & $\begin{array}{l}5.69 \mathrm{E}-2 \\
3.2 \mathrm{E}-2 \\
\end{array}$ \\
\hline & $(20,10)$ & $\begin{array}{l}\text { M. } \\
\text { Std. }\end{array}$ & $\begin{array}{c}1.04 \mathrm{E}+0 \\
7.9 \mathrm{E}-2\end{array}$ & $\begin{array}{c}1.15 \mathrm{E}+0 \\
6.6 \mathrm{E}-2\end{array}$ & $\begin{array}{c}1.03 \mathrm{E}+0 \\
7.4 \mathrm{E}-2\end{array}$ & $\begin{array}{c}9.47 \mathrm{E}-1 \\
2.2 \mathrm{E}-2\end{array}$ & $\begin{array}{l}9.11 \mathrm{E}-1 \\
8.1 \mathrm{E}-2 \\
\end{array}$ & $\begin{array}{l}5.54 \mathrm{E}-1 \\
2.1 \mathrm{E}-4 \\
\end{array}$ & $\begin{array}{c}4.13 \mathrm{E}-1 \\
3.6 \mathrm{E}-1\end{array}$ & $\begin{array}{l}5.74 \mathrm{E}-1 \\
2.7 \mathrm{E}-1\end{array}$ & $\begin{array}{l}2.64 \mathrm{E}-1 \\
1.8 \mathrm{E}-1 \\
\end{array}$ & $\begin{array}{l}1.26 \mathrm{E}-1 \\
1.1 \mathrm{E}-1 \\
\end{array}$ \\
\hline \multirow[t]{3}{*}{ FDA4 } & $(5,10)$ & $\begin{array}{l}\text { M. } \\
\text { Std. }\end{array}$ & $\begin{array}{c}2.05 \mathrm{E}+0 \\
2.0 \mathrm{E}-1\end{array}$ & $\begin{array}{c}3.80 \mathrm{E}-1 \\
2.6 \mathrm{E}-2\end{array}$ & $\begin{array}{c}7.77 \mathrm{E}-1 \\
6.8 \mathrm{E}-2\end{array}$ & $\begin{array}{c}3.97 \mathrm{E}+0 \\
1.6 \mathrm{E}+0\end{array}$ & $\begin{array}{c}1.03 \mathrm{E}+0 \\
1.3 \mathrm{E}-1\end{array}$ & $\begin{array}{c}4.17 \mathrm{E}-2 \\
4.6 \mathrm{E}-3\end{array}$ & $\begin{array}{c}6.51 \mathrm{E}+1 \\
7.3 \mathrm{E}+0\end{array}$ & $\begin{array}{l}3.23 \mathrm{E}-2 \\
4.8 \mathrm{E}-2\end{array}$ & $\begin{array}{l}2.13 \mathrm{E}-2 \\
1.1 \mathrm{E}-2\end{array}$ & $\begin{array}{l}3.20 \mathrm{E}-3 \\
1.5 \mathrm{E}-3\end{array}$ \\
\hline & $(10,10)$ & $\begin{array}{l}\text { M. } \\
\text { Std. }\end{array}$ & $\begin{array}{c}1.58 \mathrm{E}+0 \\
6.6 \mathrm{E}-2\end{array}$ & $\begin{array}{l}2.70 \mathrm{E}-1 \\
3.5 \mathrm{E}-2\end{array}$ & $\begin{array}{c}4.34 \mathrm{E}-1 \\
7.2 \mathrm{E}-2 \\
\end{array}$ & $\begin{array}{c}1.24 \mathrm{E}+0 \\
1.3 \mathrm{E}-1\end{array}$ & $\begin{array}{l}2.74 \mathrm{E}-1 \\
2.4 \mathrm{E}-2 \\
\end{array}$ & $\begin{array}{l}4.26 \mathrm{E}-2 \\
5.0 \mathrm{E}-3 \\
\end{array}$ & $\begin{array}{l}6.92 \mathrm{E}+1 \\
8.2 \mathrm{E}+0\end{array}$ & $\begin{array}{l}3.11 \mathrm{E}-2 \\
4.3 \mathrm{E}-2\end{array}$ & $\begin{array}{l}2.28 \mathrm{E}-2 \\
7.6 \mathrm{E}-3\end{array}$ & $\begin{array}{l}3.00 E-3 \\
8.7 E-3 \\
\end{array}$ \\
\hline & $(20,10)$ & $\begin{array}{l}\text { M. } \\
\text { Std. }\end{array}$ & $\begin{array}{c}5.48 \mathrm{E}-1 \\
5.7 \mathrm{E}-2\end{array}$ & $\begin{array}{l}1.80 \mathrm{E}-1 \\
2.4 \mathrm{E}-2\end{array}$ & $\begin{array}{c}3.34 \mathrm{E}-1 \\
8.3 \mathrm{E}-3\end{array}$ & $\begin{array}{c}4.34 \mathrm{E}-1 \\
5.0 \mathrm{E}-2\end{array}$ & $\begin{array}{l}1.44 \mathrm{E}-1 \\
2.0 \mathrm{E}-2\end{array}$ & $\begin{array}{c}4.41 \mathrm{E}-2 \\
4.0 \mathrm{E}-3\end{array}$ & $\begin{array}{l}7.01 \mathrm{E}+1 \\
8.5 \mathrm{E}+0\end{array}$ & $\begin{array}{l}1.16 \mathrm{E}-1 \\
6.7 \mathrm{E}-2\end{array}$ & $\begin{array}{l}4.57 \mathrm{E}-2 \\
1.2 \mathrm{E}-2\end{array}$ & $\begin{array}{l}\text { 3.39E-3 } \\
5.9 E-3\end{array}$ \\
\hline \multirow[t]{3}{*}{ FDA5 } & $(5,10)$ & $\begin{array}{l}\text { M. } \\
\text { Std. }\end{array}$ & $\begin{array}{c}6.75 \mathrm{E}+0 \\
1.9 \mathrm{E}-1 \\
\end{array}$ & $\begin{array}{c}2.76 \mathrm{E}+0 \\
2.8 \mathrm{E}-1\end{array}$ & $\begin{array}{c}3.88 \mathrm{E}+0 \\
3.1 \mathrm{E}-1\end{array}$ & $\begin{array}{c}7.08 \mathrm{E}+0 \\
1.0 \mathrm{E}+0\end{array}$ & $\begin{array}{c}2.70 \mathrm{E}+0 \\
2.2 \mathrm{E}-1\end{array}$ & $\begin{array}{c}6.38 \mathrm{E}-1 \\
6.1 \mathrm{E}-1 \\
\end{array}$ & $\begin{array}{c}9.97 \mathrm{E}-1 \\
5.5 \mathrm{E}+0\end{array}$ & $\begin{array}{l}2.78 \mathrm{E}-1 \\
1.2 \mathrm{E}-1 \\
\end{array}$ & $\begin{array}{l}2.72 \mathrm{E}-1 \\
8.3 \mathrm{E}-2\end{array}$ & $\begin{array}{l}1.20 \mathrm{E}-1 \\
7.8 \mathrm{E}-2 \\
\end{array}$ \\
\hline & $(10,10)$ & $\begin{array}{l}\text { M. } \\
\text { Std. }\end{array}$ & $\begin{array}{c}5.41 \mathrm{E}+0 \\
1.6 \mathrm{E}-1\end{array}$ & $\begin{array}{c}2.37 \mathrm{E}+0 \\
2.7 \mathrm{E}-1\end{array}$ & $\begin{array}{c}2.19 \mathrm{E}+0 \\
3.9 \mathrm{E}-1\end{array}$ & $\begin{array}{c}4.80 \mathrm{E}+0 \\
2.6 \mathrm{E}-1\end{array}$ & $\begin{array}{c}1.88 \mathrm{E}+0 \\
9.3 \mathrm{E}-2\end{array}$ & $\begin{array}{l}8.66 \mathrm{E}-1 \\
6.7 \mathrm{E}-1\end{array}$ & $\begin{array}{l}5.97 \mathrm{E}-1 \\
3.8 \mathrm{E}+0\end{array}$ & $\begin{array}{l}5.18 \mathrm{E}-1 \\
4.5 \mathrm{E}-1\end{array}$ & $\begin{array}{l}1.03 \mathrm{E}-1 \\
6.9 \mathrm{E}-2\end{array}$ & $\begin{array}{l}1.47 E-2 \\
9.5 E-3\end{array}$ \\
\hline & $(20,10)$ & $\begin{array}{l}\text { M. } \\
\text { Std. }\end{array}$ & $\begin{array}{c}2.64 \mathrm{E}+0 \\
1.1 \mathrm{E}-1\end{array}$ & $\begin{array}{c}2.02 \mathrm{E}+0 \\
1.8 \mathrm{E}-1\end{array}$ & $\begin{array}{c}1.04 \mathrm{E}+0 \\
1.1 \mathrm{E}-1\end{array}$ & $\begin{array}{c}2.15 \mathrm{E}+0 \\
1.0 \mathrm{E}-1\end{array}$ & $\begin{array}{c}1.78 \mathrm{E}+0 \\
7.1 \mathrm{E}-2\end{array}$ & $\begin{array}{c}1.51 \mathrm{E}+0 \\
5.4 \mathrm{E}-1\end{array}$ & $\begin{array}{c}1.47 \mathrm{E}+0 \\
5.4 \mathrm{E}+0\end{array}$ & $\begin{array}{l}1.24 \mathrm{E}+0 \\
7.2 \mathrm{E}-1\end{array}$ & $\begin{array}{l}3.62 \mathrm{E}-2 \\
3.7 \mathrm{E}-2\end{array}$ & $\begin{array}{l}7.10 \mathrm{E}-3 \\
6.3 \mathrm{E}-3\end{array}$ \\
\hline \multirow[t]{3}{*}{ dMOP1 } & $(5,10)$ & $\begin{array}{l}\text { M. } \\
\text { Std. }\end{array}$ & $\begin{array}{l}3.93 \mathrm{E}-2 \\
3.81 \mathrm{E}-2\end{array}$ & $\begin{array}{l}1.73 \mathrm{E}-1 \\
3.3 \mathrm{E}-2\end{array}$ & $\begin{array}{c}2.86 \mathrm{E}-1 \\
3.6 \mathrm{E}-1\end{array}$ & $\begin{array}{c}4.64 \mathrm{E}-2 \\
3.6 \mathrm{E}-2\end{array}$ & $\begin{array}{c}3.75 \mathrm{E}-2 \\
2.5 \mathrm{E}-2\end{array}$ & $\begin{array}{c}3.29 \mathrm{E}-1 \\
9.9 \mathrm{E}-5\end{array}$ & $\begin{array}{c}3.07 \mathrm{E}-1 \\
1.2 \mathrm{E}-1\end{array}$ & $\begin{array}{l}3.77 \mathrm{E}-3 \\
5.7 \mathrm{E}-4\end{array}$ & $\begin{array}{l}1.21 \mathrm{E}-3 \\
4.3 \mathrm{E}-4\end{array}$ & $\begin{array}{l}1.02 E-3 \\
3.7 E-4\end{array}$ \\
\hline & $(10,10)$ & $\begin{array}{l}\text { M. } \\
\text { Std. }\end{array}$ & $\begin{array}{l}2.28 \mathrm{E}-2 \\
2.0 \mathrm{E}-2 \\
\end{array}$ & $\begin{array}{l}1.12 \mathrm{E}-1 \\
2.0 \mathrm{E}-2 \\
\end{array}$ & $\begin{array}{c}9.27 \mathrm{E}-2 \\
1.3 \mathrm{E}-1 \\
\end{array}$ & $\begin{array}{c}2.57 \mathrm{E}-2 \\
1.5 \mathrm{E}-2 \\
\end{array}$ & $\begin{array}{l}1.90 \mathrm{E}-2 \\
1.4 \mathrm{E}-2 \\
\end{array}$ & $\begin{array}{l}3.29 \mathrm{E}-1 \\
5.9 \mathrm{E}-5 \\
\end{array}$ & $\begin{array}{c}3.29 \mathrm{E}-1 \\
3.3 \mathrm{E}-5 \\
\end{array}$ & $\begin{array}{l}2.03 \mathrm{E}-3 \\
1.0 \mathrm{E}-3 \\
\end{array}$ & $\begin{array}{l}2.53 \mathrm{E}-3 \\
3.4 \mathrm{E}-4 \\
\end{array}$ & $\begin{array}{l}3.41 E-4 \\
2.1 E-4 \\
\end{array}$ \\
\hline & $(20,10)$ & $\begin{array}{l}\text { M. } \\
\text { Std. }\end{array}$ & $\begin{array}{l}1.71 \mathrm{E}-2 \\
1.4 \mathrm{E}-2 \\
\end{array}$ & $\begin{array}{l}5.65 \mathrm{E}-2 \\
8.1 \mathrm{E}-3 \\
\end{array}$ & $\begin{array}{c}6.02 \mathrm{E}-2 \\
8.1 \mathrm{E}-2 \\
\end{array}$ & $\begin{array}{l}1.59 \mathrm{E}-2 \\
7.9 \mathrm{E}-3\end{array}$ & $\begin{array}{l}1.80 \mathrm{E}-2 \\
1.3 \mathrm{E}-2 \\
\end{array}$ & $\begin{array}{c}3.29 \mathrm{E}-1 \\
3.6 \mathrm{E}-5 \\
\end{array}$ & $\begin{array}{c}3.29 \mathrm{E}-1 \\
1.7 \mathrm{E}-5\end{array}$ & $\begin{array}{l}3.07 \mathrm{E}-3 \\
5.6 \mathrm{E}-4\end{array}$ & $\begin{array}{l}3.49 \mathrm{E}-3 \\
2.2 \mathrm{E}-4\end{array}$ & $\begin{array}{l}8.94 E-4 \\
1.8 E-4\end{array}$ \\
\hline \multirow[t]{3}{*}{ dMOP2 } & $(5,10)$ & $\begin{array}{l}\text { M. } \\
\text { Std. }\end{array}$ & $\begin{array}{c}8.06 \mathrm{E}-1 \\
1.1 \mathrm{E}-1\end{array}$ & $\begin{array}{c}3.03 \mathrm{E}-1 \\
4.9 \mathrm{E}-2\end{array}$ & $\begin{array}{c}3.95 \mathrm{E}-1 \\
3.9 \mathrm{E}-2\end{array}$ & $\begin{array}{c}9.04 \mathrm{E}-1 \\
7.3 \mathrm{E}-2\end{array}$ & $\begin{array}{c}8.71 \mathrm{E}-2 \\
1.9 \mathrm{E}-2\end{array}$ & $\begin{array}{l}1.08 \mathrm{E}-1 \\
8.2 \mathrm{E}-5\end{array}$ & $\begin{array}{l}1.98 \mathrm{E}-2 \\
2.2 \mathrm{E}-1\end{array}$ & $\begin{array}{l}1.32 \mathrm{E}-2 \\
2.4 \mathrm{E}-2\end{array}$ & $\begin{array}{l}1.33 \mathrm{E}-1 \\
8.0 \mathrm{E}-2\end{array}$ & $\begin{array}{l}1.08 \mathrm{E}-1 \\
2.5 \mathrm{E}-2\end{array}$ \\
\hline & $(10,10)$ & $\begin{array}{l}\text { M. } \\
\text { Std. }\end{array}$ & $\begin{array}{l}2.90 \mathrm{E}-1 \\
2.5 \mathrm{E}-2\end{array}$ & $\begin{array}{l}2.07 \mathrm{E}-1 \\
2.4 \mathrm{E}-2\end{array}$ & $\begin{array}{l}1.17 \mathrm{E}-1 \\
4.3 \mathrm{E}-2\end{array}$ & $\begin{array}{c}4.46 \mathrm{E}-1 \\
4.2 \mathrm{E}-2\end{array}$ & $\begin{array}{c}3.59 \mathrm{E}-2 \\
1.1 \mathrm{E}-2\end{array}$ & $\begin{array}{c}1.08 \mathrm{E}-1 \\
6.1 \mathrm{E}-5\end{array}$ & $\begin{array}{c}8.61 \mathrm{E}-2 \\
1.2 \mathrm{E}-1\end{array}$ & $\begin{array}{l}1.80 \mathrm{E}-3 \\
1.2 \mathrm{E}-3\end{array}$ & $\begin{array}{l}1.08 \mathrm{E}-1 \\
2.9 \mathrm{E}-2\end{array}$ & $\begin{array}{l}1.16 \mathrm{E}-1 \\
5.2 \mathrm{E}-3\end{array}$ \\
\hline & $(20,10)$ & $\begin{array}{l}\text { M. } \\
\text { Std. }\end{array}$ & $\begin{array}{l}.50 \mathrm{E}-2 \\
1.2 \mathrm{E}-2 \\
\end{array}$ & $\begin{array}{l}1.09 \mathrm{E}-1 \\
1.5 \mathrm{E}-2 \\
\end{array}$ & $\begin{array}{c}5.65 \mathrm{E}-2 \\
6.2 \mathrm{E}-3 \\
\end{array}$ & $\begin{array}{c}1.98 \mathrm{E}-1 \\
1.4 \mathrm{E}-2 \\
\end{array}$ & $\begin{array}{l}1.85 \mathrm{E}-2 \\
1.1 \mathrm{E}-2 \\
\end{array}$ & $\begin{array}{l}1.08 \mathrm{E}-1 \\
3.3 \mathrm{E}-5 \\
\end{array}$ & $\begin{array}{c}8.57 \mathrm{E}-2 \\
1.2 \mathrm{E}-1 \\
\end{array}$ & $\begin{array}{l}4.73 \mathrm{E}-3 \\
1.8 \mathrm{E}-3 \\
\end{array}$ & $\begin{array}{l}7.98 \mathrm{E}-2 \\
4.0 \mathrm{E}-2\end{array}$ & $\begin{array}{l}6.65 \mathrm{E}-2 \\
4.7 \mathrm{E}-2 \\
\end{array}$ \\
\hline \multirow[t]{3}{*}{ dMOP3 } & $(5,10)$ & $\begin{array}{l}\text { M. } \\
\text { Std. }\end{array}$ & $\begin{array}{l}9.51 \mathrm{E}-1 \\
3.4 \mathrm{E}-2 \\
\end{array}$ & $\begin{array}{l}1.05 E-1 \\
1.6 \mathrm{E}-2\end{array}$ & $\begin{array}{c}4.22 \mathrm{E}-1 \\
1.5 \mathrm{E}-2 \\
\end{array}$ & $\begin{array}{l}7.61 \mathrm{E}-1 \\
5.3 \mathrm{E}-2 \\
\end{array}$ & $\begin{array}{l}4.07 \mathrm{E}-1 \\
2.4 \mathrm{E}-2\end{array}$ & $\begin{array}{c}1.13 \mathrm{E}+1 \\
1.2 \mathrm{E}+0\end{array}$ & $\begin{array}{c}1.10 \mathrm{E}+1 \\
1.3 \mathrm{E}-1 \\
\end{array}$ & $\begin{array}{l}1.89 \mathrm{E}+0 \\
6.2 \mathrm{E}-1 \\
\end{array}$ & $\begin{array}{l}3.57 \mathrm{E}-1 \\
4.0 \mathrm{E}-1\end{array}$ & $\begin{array}{l}1.42 \mathrm{E}-1 \\
1.4 \mathrm{E}-1 \\
\end{array}$ \\
\hline & $(10,10)$ & $\begin{array}{l}\text { M. } \\
\text { Std. }\end{array}$ & $\begin{array}{c}4.74 \mathrm{E}-1 \\
2.8 \mathrm{E}-2\end{array}$ & $\begin{array}{c}6.57 \mathrm{E}-2 \\
1.3 \mathrm{E}-2\end{array}$ & $\begin{array}{c}2.79 \mathrm{E}-1 \\
2.7 \mathrm{E}-2\end{array}$ & $\begin{array}{c}4.54 \mathrm{E}-1 \\
2.8 \mathrm{E}-2\end{array}$ & $\begin{array}{l}3.18 \mathrm{E}-1 \\
2.9 \mathrm{E}-2\end{array}$ & $\begin{array}{c}2.49 \mathrm{E}+0 \\
1.1 \mathrm{E}+0\end{array}$ & $\begin{array}{c}2.63 \mathrm{E}+0 \\
2.8 \mathrm{E}-1\end{array}$ & $\begin{array}{l}1.04 \mathrm{E}+0 \\
5.0 \mathrm{E}-1\end{array}$ & $\begin{array}{l}1.74 \mathrm{E}+1 \\
3.0 \mathrm{E}-1\end{array}$ & $\begin{array}{l}1.69 \mathrm{E}+1 \\
3.1 \mathrm{E}+0\end{array}$ \\
\hline & $(20,10)$ & $\begin{array}{l}\text { M. } \\
\text { Std. }\end{array}$ & $\begin{array}{c}2.76 \mathrm{E}-1 \\
2.5 \mathrm{E}-2 \\
\end{array}$ & $\begin{array}{c}3.63 \mathrm{E}-2 \\
1.3 \mathrm{E}-2\end{array}$ & $\begin{array}{c}2.21 \mathrm{E}-1 \\
1.5 \mathrm{E}-2 \\
\end{array}$ & $\begin{array}{l}2.87 \mathrm{E}-1 \\
2.0 \mathrm{E}-2 \\
\end{array}$ & $\begin{array}{l}2.15 \mathrm{E}-1 \\
3.0 \mathrm{E}-2 \\
\end{array}$ & $\begin{array}{l}1.63 \mathrm{E}+1 \\
1.9 \mathrm{E}+0\end{array}$ & $\begin{array}{c}1.73 \mathrm{E}+1 \\
1.3 \mathrm{E}-1 \\
\end{array}$ & $\begin{array}{l}2.44 \mathrm{E}+0 \\
7.2 \mathrm{E}-1\end{array}$ & $\begin{array}{l}1.58 \mathrm{E}+1 \\
3.0 \mathrm{E}+0 \\
\end{array}$ & $\begin{array}{l}1.55 \mathrm{E}+1 \\
3.8 \mathrm{E}+0 \\
\end{array}$ \\
\hline
\end{tabular}

